\title{
Modernising the Constitution - A Crown Act
}

\author{
Graham McBain ${ }^{1,2}$ \\ ${ }^{1}$ Peterhouse, Cambridge, UK \\ ${ }^{2}$ Harvard Law School, USA \\ Correspondence: Graham McBain, 21 Millmead Terrace, Guildford, Surrey GU2 4AT, UK. E-mail: \\ gsmcbain@aol.com
}

\author{
Received: October 29, 2020 Accepted: November 18, 2020 Online Published: November 23, 2020 \\ doi:10.5539/ilr.v10n1p13 \\ URL: https://doi.org/10.5539/ilr.v10n1p13
}

Given the growth of dictatorships around the world and their intent to undermine democracy - including that in the UK - it is important that our Constitution be: accessible, transparent, intelligible and robust. Unfortunately, it is none of these things. Indeed, it is little more than a patchwork of common law cases supplemented by legislation. ${ }^{1}$ Much of this is very antiquated. And, a lot is obsolete. ${ }^{2}$ Much, also, is scarcely intelligible to lawyers (save for a few constitutional lawyers) ${ }^{3}$ and most of it is wholly unintelligible to the general public. Finally, there are many gaps and inconsistencies. The purpose of this article is to argue the need for a Crown Act. One which sets out almost all ${ }^{4}$ of the Crown's prerogatives and indicates which should be dispensed with. The purpose of this article is, also, to argue that what is required is not only a Crown Act, but also the following, $\mathrm{a}:$

- Parliament Act; and a

- Government Act.

In due course, all three of these could be amalgamated into one Constitution Act. However, it is much better to set matters out independently at first, in order to enable Parliamentarians ('MPs') and others to see what is what. It also prevents things being missed.

Finally, a review of Crown prerogatives is timely. Indeed, long overdue ${ }^{5}$ since such are becoming less and less relevant given that the role of the sovereign today is a formal (ceremonial) one unlike, in earlier times, when the sovereign exercised executive power in person. The result is that the need for the law - and the courts - to uphold special legal rights (also called 'prerogatives' or 'pre-eminences' $)^{6}$ in respect of the sovereign has greatly diminished and it will continue to do so since it is, manifestly, the will of the general public in a democratic society that Parliament has the pre-eminent role in the enactment of legislation (to which the Crown is also made subject). Also, that Parliament oversights the direction (and behaviour) of the

\footnotetext{
${ }^{1}$ Halsbury, Laws of England ( $4^{\text {th }}$ ed), vol 8(2), para 1, the 'United Kingdom constitutional law is an incomplete system, consisting of piecemeal legislation, ancient common law doctrines, and constitutional conventions which are binding in a political rather than a legal sense. The United Kingdom constitution lacks the coherence of comprehensive modern constitutions.'

${ }^{2}$ In 1908, the great legal historian, Maitland, talked of prerogatives of 'doubtful existence' and 'prerogatives which exist by sufferance, merely because no one has thought it worthwhile to abolish them.' FW Maitland, The Constitutional History of England (CUP, 1963), p 421.

${ }^{3}$ Even many modern constitutional lawyers get it wrong since they have little knowledge of legal history and they cannot read the old latin or law French. Further, they do not know (or trouble to find out) what older law books and other texts on the constitution exist (much useful material is contained in the old legal abridgments and the Rolls of Parliament).

${ }^{4}$ Crown prerogatives relating to Parliament are better placed in a Parliament Act. And, those relating to the civil service, the foreign office and its diplomatic functions etc, are better placed in a Government Act. Finally, others should be in specific legislation (for example, an Armed Forces Act, when the prerogative specifically relates to military matters). Thus, ease of reference is important.

${ }^{5}$ See House of Commons, Public Administration Select C-ee, 4th Report of Session 2003-4. Taming the Prerogative: Strengthening Ministerial Accountability to Parliament. HC 422 (16 March 2004)('HC'). See also M1 in this article (in 1), pp 4-5.

${ }^{6}$ From Tudor times, the courts began to recognise a distinction between the Crown comprising the sovereign in person and the Crown comprising an executive institution (the State). It did this by recognising the sovereign both as a human being (who died) and the sovereign as a corporation sole (a legal entity, which did not). More especially, it recognised the latter as having a political function. Thus, emerged the idea of the sovereign having a body natural and a body politic (or political body). See EH Kantorowicz, The King's Two Bodies: A Study in Medieval Political Theology (Princeton, 1957). See also M4, p 14.
} 
executive - including the civil service. Further, the Crown, in practice, today, is subject to Parliament - the expression the 'Crown' referring both to the sovereign in person (i.e. in the body natural) ${ }^{7}$ and in the body politic. ${ }^{8}$

In conclusion, this article argues the need for a Crown Act. This Act should also place in legislation (in a modern format) the contents of charters which regulate the duchies of Cornwall and Lancaster since these duchies comprise appanages of the Crown held by the sovereign in the body politic.

\section{INTRODUCTION}

It is possible to list - in chronological order - all constitutional legislation still extant (see Appendix A). Also, to list all (or almost all) the principal texts on constitutional law (see Appendix B). However, of greater use, generally, to indicate the legal history of the prerogatives of the Crown (the 'Crown prerogatives') are the following:

- Staunford, An Exposition of the King 's Prerogative (1567-1607); ${ }^{9}$

- Coke, Institutes of the Laws of England (1628-41); ${ }^{10}$

- Blackstone, Commentaries on the Laws of England (1765-9); ${ }^{11}$

- $\quad$ Bacon, A New Abridgment of the Law ( $5^{\text {th }}$ ed, 1795-8); ${ }^{12}$

- J Chitty Jun, A Treatise of the Law of the Prerogatives of the Crown (1820); $;^{13}$

- Halsbury, Laws of England. ${ }^{14}$

Prior to the $17^{\text {th }}$ century, the eminence of the sovereign was such that it was somewhat dangerous to seek to legally analyse his prerogative. ${ }^{15}$ Further, all of Staunford, Coke and Blackstone were cautious (perhaps, unduly deferential) in what they said. The first modern text on the prerogatives of the Crown was that of Chitty in 1820 . His was a treatise which sought to comprehensively cover almost all the Crown prerogatives - albeit, it was not highly detailed. ${ }^{16}$ An excellent analysis of Crown prerogatives was provided in volumes 6 and 7 of the first edition of Halsbury in 1909. ${ }^{17}$ Thereafter, later editions of Halsbury have become increasingly terse and fragmented in their analysis. This has resulted in the loss of a comprehensive assemblage of the prerogatives. There were also more modern legal texts on constitutional law from the Victorian period. However, many of these have fallen by the wayside, to be replaced by student or academic works which do not emphasise sufficiently that many Crown prerogatives are obsolete or rarely exercised. And, that almost all are now part of the sovereign's body politic -

\footnotetext{
${ }^{7}$ The legal writer, Bracton, as long ago as c. 1240-50, asserted that 'lex facit regem' ('the law makes the king') see H Bracton (trans Thorne), On the Law and Customs of England (Cambridge UP, 1968-76), vol 2, p 33. However, it was not until after the Civil War (1642-9) as well as the deposition of James II (1685-8, who was held to have abdicated the throne by fleeing) with the election by Parliament of William of Orange (William III (1688-1702) that this became more of a reality. The Bill of Rights 1688 also asserted (and continues to do so) that 'the laws of England are the birthright of the people thereof; and all the kings and Queens who shall ascend the throne of this realm ought to administer the government of the same, according to the said laws.' (italics supplied)

${ }^{8}$ The words the 'executive', the 'Crown' (when not used to refer to the sovereign in person) the 'body politic' and the 'State' are synonyms. To a certain extent the 'government' is the same. However, the latter expression is, often, used in a more restricted sense to refer to the political party in power. See generally, M1, p 4. AW Bradley \& KD Ewing, Constitutional and Administrative Law (15th ed, 2011), p 33 'The Queen may reign, but it is the prime minister and other ministers who rule.'

${ }^{9} \mathrm{~W}$ Staunford, Exposition of the Kinges Prerogative collected out of the great Abridgement of Fitzherbert, and other olde writers of the lawes of England; [with] the process to the same prerogative appertayning.' The first edition was in 1567. Later editions were published in 1567, 1568, 1573, 1577, 1590 and 1607.

${ }^{10} \mathrm{E}$ Coke, Institutes of the Laws of England (W Clarke \& Sons, London, last ed, 1824). See also Sir Matthew Hale's Prerogatives of the King, DEC Yale (ed), Selden Society, vol 92 (London, 1976).

${ }^{11}$ W Blackstone, Commentaries on the Laws of England (Oxford, Clarendon Press, $1^{\text {st }}$ ed, 1765-9, University of Chicago Press, rep 1979).

${ }^{12} \mathrm{M}$ Bacon, $A$ New Abridgment of the Law (5th ed, 7 vols, 1798). Volume 5 (prerogative) contains material on the Crown prerogative. The first edition of Bacon was in 1736-66 (5 vols). The last was in 1832 (8 vols). Bacon is useful since it bridged the historical period from Blackstone (1765) to Chitty (1820) and it was detailed. It is clear that Chitty used Bacon when compiling his own text.

${ }^{13} \mathrm{~J}$ Chitty Jun, A Treatise of the Law of the Prerogatives of the Crown (Butterworths, London, 1820).

${ }^{14}$ The first edition was in 1907-17 (see n 17). The relevant volumes on constitutional law were vols 6 and 7.

${ }^{15}$ James I (1603-25) told the House of Commons, in a petition made to him in 1621, that 'In the body of your petition, you usurp upon our royal prerogative, and meddle with things far above your reach'. See J Rushworth, Historical Collections of Private Passages of State, Weighty Matters in Law, Remarkable Proceedings in Five Parliaments (1721), vol 1, p 47. See also M14, p 58. Blackstone, n 11, vol 1, p 230 'a topic, that in some former ages was thought too delicate and sacred to be profaned by the pen of a subject'. See also M4, p 15, n 9.

${ }^{16}$ A large number of the smaller prerogatives were obsolete (or becoming so) by 1820 . Thus, Chitty did not deal with them in detail.

${ }^{17}$ Halsbury, Laws of England ( $1^{\text {st }}$ ed, 1907-17 with supp; $2^{\text {nd }}$ ed, 1931-42, with supp; 3rd ed, 1953- 63 with supp; 4th ed, 1973 with supp; 5th ed, 2008 with supp).
} 
as opposed to emanating from her decision in person. ${ }^{18}$ Due to this, a series of detailed articles by the author have sought to trace the history of many of the Crown prerogatives - especially, the minor ones. These articles comprise the following:

- Expanding Democracy - Transferring the Crown Prerogative to Parliament. (2014) Rev. of European Studies, vol 6, no 1, pp 83-126 ('M1').

- $\quad$ Modernising the Monarchy - in Legal Terms. (2010) KLJ, vol 21(3), 535-60 ('M2').

- Modernising the Monarchy - in Legal Terms. Part 2. (2011) KLJ, vol 22(1), 95-118 ('M3').

- Abolishing Obsolete Crown Prerogatives relating to the Military. (2011) Nottingham LJ, vol 20, 14-37 ('M4').

- Abolishing some more Obsolete Crown Prerogatives. (2011) Liverpool LR, vol 32, no 1, 65-92 ('M5').

- The Religion of the Queen - Time for Change. (2011) Queensland LR, 1-48 ('M6').

- Abolishing some Obsolete Constitutional Legislation. (2011) Coventry LJ, vol 16, issue 1, 1-18. ('M7').

- Modernising the Monarchy in Legal Terms - Part 3. (2012) KLJ, vol 23, 1-25. ('M8').

- Modernising the Monarchy in Legal Terms - Part 4. (2012) KLJ, vol 23, 285-311. ('M9').

- Modernising the Monarchy in Legal Terms - Part 5. (2014) KLJ, vol 25, 440-66.('M10').

- $\quad$ Liberties and Customs of the City of London - Are there any Left? (2013) Int. Law Research, vol 2, no 1, 32-95. ('M11').

- $\quad$ Time to Abolish the Duchy of Lancaster. (2013) Rev. of European Studies, vol 5, no 4, 172-93 ('M12').

- $\quad$ Time to Abolish the Duchy of Cornwall ? (2013) Rev. of European Studies, vol 5, no 5, 40-58 ('M13').

- Abolishing Obsolete Crown Prerogatives relating to Martial Law,Conscription \& Billeting. (2012) Int. Law Research, vol 1, no 1, 13-62 ('M14').

- Abolishing some more Obsolete Crown Prerogatives: Part 2. (2011) Liverpool LR, vol 32, 275-315 (Dec 2011, online) ('M15').

- The Case for Abolishing Manorial Franchises and Customs.(2013) Coventry LJ, vol 18, no 1, 43-68 ('M16').

- Modernising the Law of Prize. (2014) Journal of Business Law, no 6, 465-83 ('M17').

- $\quad$ The Charters of the Cinque Ports - Are they Still Needed ? (2013) Rev. of European Studies, vol 5, no 2, 90-126 ('M18').

As a result, many Crown prerogatives will be summarised in this article with more detailed analysis being left to the above.

\section{OVERVIEW}

This article seeks to provide an overview of almost all the Crown prerogatives. As previously noted, why legislation is needed (i.e. a Crown Act) is that so many prerogatives are obsolete and others are no longer required. Others need to be modernised. Thus, the intention should be that legislation should (ultimately) provide that all common law Crown prerogatives are abolished - leaving the few still required to be set out in statutory form.

Is it possible to list all Crown prerogatives? The answer is 'yes'. Albeit, one or two more obscure Crown prerogatives might still creep out of the woodwork in due course. Thus, a rider in legislation is needed; ${ }^{19}$

Is the drafting of legislation on the Crown difficult? The answer (generally) is 'no' since it is simply a matter of referring to many major (and minor) prerogatives the tenor of which has been formulated by the common law (or, in a few instances, in legislation);

Should all Crown prerogatives be contained in one Crown Act? The answer is ' $n o$ '. Crown prerogatives relating to Parliament or to the Government (for example) are better set out in legislation concerning to the same, in order to be more easily accessible and understood. Further, a number are better set out in legislation to which they appertain (e.g. Crown prerogatives relating to the military would be better set out in an Armed Forces Act).

\section{THE SOVEREIGN IN PERSON}

There are certain prerogatives which relate directly to the sovereign in a personal capacity. These are now considered:

\footnotetext{
${ }^{18}$ Those in which the sovereign can truly be said to exercise her own judgment in person are, today, few and far between. Whether she wants to eat sturgeon or whales is one. Whether she will permit the marriage of one of 6 persons in line to the throne pursuant to the Succession to the Crown Act 2013 may be another - albeit, she would likely seek advice and opinions on this.

${ }^{19}$ This should enable, by means of an SI, the preservation of an overlooked common law Crown prerogative for up to (say) 3 years, to enable legislative provision to be made for it, where required.
} 
- $\quad$ Person. Who is the sovereign ? Old legislation refers to the present sovereign, Elizabeth II (1952- ), by reference to her descent through the Georges (1-VI), from Sophia, Electress of Hanover (1630-1714) ${ }^{20}$ However, today, such is not necessary since no one seriously doubts that Elizabeth II is descended from the same. Thus, reference may be made, in a Crown Act, to 'Queen Elizabeth II and the heirs of her body'. The latter expression derives from early legislation. ${ }^{21}$ Since it is possible for the sovereign to be a 'successor' - as opposed to an 'heir of the body' ${ }^{22}$ - a Crown Act should also provide for the same. The word 'sovereign' in a Crown Act is a more modern term than 'monarch'. Thus, it is to be preferred. Also, reference to the 'sovereign', generally, avoids gender issues and capitalisation ('Her Majesty', 'His Majesty' etc);

- $\quad$ Style \& Title. Provision is made for this in the Royal Titles Act $1953 .{ }^{23}$ A Crown Act should modernise (update) this wording. ${ }^{24}$ As for stating this in a proclamation, it is suggested that a SI would be better, today, since the same, then, has Parliamentary recognition and sanction. This may, also, be easier for the sovereign: ${ }^{25}$

- Demise (Death). While the sovereign - as a person - may die, in the body politic this is not so. Further, such is important in order to ensure a seamless succession. Especially, in respect of: (a) the holding of any Crown office (or that of the principality of Wales and the duchies of Cornwall and Lancaster); (b) membership of the privy council; (c) claims (or legal proceedings) by (or against) the Crown; and (d) the use of the Great Seal or other public seal. Presently, matters relating to the sovereign's demise are set out in old legislation. ${ }^{26}$ A Crown Act should consolidate, and modernise, this wording;

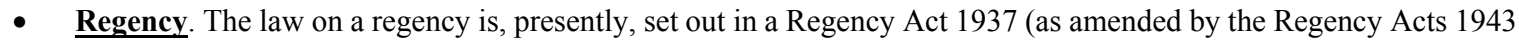
and 1953). Such should be set out (with minor amendment) in a schedule to a Crown Act;

- $\quad$ Legal Nature. The sovereign is a corporation sole. ${ }^{27}$ This should be stated in a Crown Act;

- $\quad$ Body Politic. The sovereign has both a body natural (a physical body) and a body politic. The former dies; the latter does not. The effect of the latter is that sovereignty is never in abeyance or suspended. Not even for a moment. The last breath of the dying sovereign is immediately followed by the first of his (or her) successor. ${ }^{28}$ Thus, provision could be made in a Crown Act (to put the latter beyond doubt) that: 'The sovereign, in the body politic, is never in abeyance or suspended (that is, the sovereign in the body politic never dies);'

- Private Ownership of Property. Until $1800,{ }^{29}$ there was uncertainty as to whether the sovereign, in person, could privately own real property. While it is now clear that the sovereign can (the Queen privately owns Sandringham and Balmoral, for example) it is unclear, at present, whether - in respect of property (real or personal) - the general

\footnotetext{
${ }^{20}$ Elizabeth II is sovereign in accordance with the Settlement Act 1700 (it provided for the throne to go to Sophia, Electress of Hanover and the 'heirs of her body' and the throne passed to George I (1714-27), her son, from whom Elizabeth II is descended. Stating that Elizabeth II is sovereign enables much historical verbiage to be removed from that Act as well as from the Union with Scotland Act 1706, art 2 (and its counterpart, the Union with England Act 1707, art 2). Also, the Bill of Rights 1688, s 1 (this Act was required to be amended by the Act of 1700 when Queen Mary (consort of William III) died without childen and the only child of Anne of Denmark (later, Queen Anne (1702-14) died. The effect of these events was to pass sucession to the throne of England, after the demise of William III, to Sophia, Electress of Hanover. However, she died before Queen Anne. Thus, the throne went to her son, George I.

${ }^{21}$ The phrase 'and the heirs of her body' may be found in the Bill of Rights 1688 and the Act of Settlement 1700. For the legal purport of 'heirs', see R Megarry \& HWR Wade, The Law of Real Property (1975, 4th ed), pp 52, 55-6. See also Chitty, n 13, p 208.

${ }^{22}$ For example, William of Orange (later, William III) was not an 'heir of the body 'of James II (1685-8). However, Parliament chose him as successor to the throne. The word 'successor' is implied by legislation - even if not expressly stated - on the basis that the Crown never dies. For successors, see $\mathbf{2 1}$.

${ }^{23}$ The Royal Titles Act 1953, s 1, states: 'The assent of the Parliament of the [UK] is hereby given to the adoption by [HM], for use in relation to the [UK] and all other the territories for whose foreign relations her government in the [UK] is responsible, of such style and titles as [HM] may think fit having regard to the said agreement, in lieu of the style and titles at present appertaining to the Crown, and to the issue by [HM] for that purpose of her royal proclamation under the great seal of the realm.' The words in italics would seem otiose.

${ }^{24}$ See $n 23$ above.

${ }^{25}$ For example, the sovereign is declared to be 'Defender of the Faith'. This title was given to Henry VIII (1507-49) in legislation (now repealed) as defender of the (newly created) Church of England - even though it had, originally, been applied to him by the Pope for defending the Catholic faith (see M6, p 27). If removed in a SI, such would indicate that Parliament (i.e. MP's generally) were happy to acceed to any dropping of this title.

${ }^{26}$ viz. The Demise of the Crown Act 1702, Sucession to the Crown Act 1707, Demise of the Crown Act 1727, Representation of the People Act 1867, s 51, Sheriffs Act 1887, s 3(3) and the Demise of the Crown Act 1901. See M3, pp 104-9.

${ }^{27}$ Blackstone, n 11, vol 1, p 457 'the king is a corporation sole.' (following Coke). See also GS McBain, Abolishing Deeds, Specialites and Seals - Part 1 (2006) 20(1), Commercial Law Quarterly, p 26. Also, Chitty, n 13, pp 122, 208.

${ }^{28}$ Chitty (writing in 1820), n 13, p 5 'The perpetuity of the Crown is expressed by the quaint maxim that the king never dies; by which is meant that on the death of the king, the prerogatives and politic capacities of the supreme magistrate, instantly vest, without a moment's interregnum, in his successor.' Ibid., p 11 'it is a maxim in the English law that the king never dies: his political existence is never in abeyance or suspended.'

${ }^{29}$ See Crown Private Estate Act 1800 (extant). Also, M2, pp 556-7.
} 
law will apply or whether the sovereign might be able to claim any immunity (including immunity from civil liability). It would seem reasonable that the general law should now apply (i.e. without any prerogative). A Crown Act should state this; ${ }^{30}$

- $\quad$ Sovereign to Act according to Law. The Act of Settlement 1700 states: 'the laws of England are the birthright of the people thereof and all the kings and queens who shall ascend the throne of this realm [i.e. the sovereign] ought to administer the government of the same according to the said laws and all their officers and ministers ought to serve them respectively according to the same. ${ }^{31}$ This (picturesque) wording ought to be preserved (as modernised) in a Crown Act since it emphasizes that the sovereign must not act arbitrarily but according to law;

- $\quad$ Funding. Since 1760, the sovereign has received State funding in the form of a civil list. ${ }^{32}$ The present legislation is the Sovereign Grant Act 2011. There are, also, two antiquated sections of the Civil List Act 1837 extant. These do not apply to the sovereign as such but provide for State pensions (of up to $£ 15 \mathrm{k}$ pa) to persons who have by their: (a) personal service to the Crown; (b) perfomance of public duties; or (c) useful discoveries in science and attainments in literature and the arts, merited the gracious consideration of the sovereign and the gratitude of the country. ${ }^{33}$ These two Acts (with the wording modernised) should be set out in a Crown Act (a schedule would be fine).

In conclusion, a Crown Act should set out the above matters in modern form.

\section{SUCCESSION}

Until recently, sucession to the Crown followed the male line under the principal of primogeniture. However, the Succession to the Crown Act 2013 (s 1) provides that the gender of a person born after 28 October 2011 does not give that person (or that person's descendents) precedence over any other person (wherever born).

- Also, ancient legislation - the Status of Children Born Abroad Act 1350-2 - provides that the birth of a child of the sovereign abroad does not affect their right to inherit; ${ }^{34}$

- The Succession to the Crown Act 2013 also requires the consent of the sovereign to the marriage of one of 6 persons next in line of sucession to the Crown. Without it, they are disqualified from succeeding; ${ }^{35}$

- Pursuant to the common law, the sovereign cannot alter succession to the Crown in her will. ${ }^{36}$ That is, she cannot pass sovereignty to a person of her own choosing.

In conclusion, provision should be made for these matters in a Crown Act.

\section{IMMUNITY \& ARREST}

There are certain personal immunities accorded to the sovereign, viz.

- Immunity. From early history, the sovereign has been legally held to have criminal and civil immunity. This, in order to perform his/her office. ${ }^{37}$ However, the latter is not complete in that there are common law remedies available of: (a) petition of right; (b) suit against the Attorney-General; ${ }^{38}$

\footnotetext{
${ }^{30}$ The Act of 1800 (see n 29) and other legislation governing the private estate can, then, be repealed save where specific sections are still required.

${ }^{31}$ See also Chitty, n 13, p 7.

${ }^{32}$ The hereditary revenues of the sovereign were surrendered by George III in 1760 (1 Geo III c 1) in return for civil list revenues of $£ 800,000$. See also M2, p 539.

${ }^{33}$ Since pensions are now only given pursuant to (c) nowadays, it may be appropriate to delete (a) and (b). Also, since the role of the sovereign in such matters is now formal, the words 'gracious consideration of their sovereign' can be deleted.

${ }^{34}$ : 'the law of the Crown of England is, and always hath been such, that the children of the kings of England, in whatsoever parts they be born, in England or elsewhere, be able and ought to bear the inheritance after the death of their ancestors; which law our....lord the king, the...prelates, earls, barons, and other great men, and all the commons assembled in this Parliament, do approve and affirm for ever...'. See also Chitty, n 13, pp 405-6. See generally, M2, pp 553-4.

${ }^{35}$ For the position prior to this Act, see M3, pp 111-6.

${ }^{36}$ See Halsbury (5th ed), n 17, vol 29, para 66 'The sovereign cannot grant away the right to the Crown by testament.' Such does not prevent the sovereign (in effect) transferring the right to the Crown by abdicating.

${ }^{37}$ Thus, negligence or dishonesty cannot be attributed to the sovereign. Instead, it was attributed to her ministers or her officials (such as by the legal expression of the sovereign being 'deceived' in her grant). See also M1, pp 12-6.

${ }^{38}$ See Halsbury (5th ed), n 17, vol 29, para 65. Also, Chitty, n 13, pp 339-52. Halsbury, para 56, states that the sovereign is 'inviolable' . However, such is too wide a proposition today and it is obscure in meaning. So too, to ascribe to the sovereign 'absolute perfection' or that the sovereign can do no 'wrong'. (ibid, para 57). See also Chitty, n 13, p 5.
} 
- $\quad$ Arrest. As part of the the sovereign's immunity, it has been held that the sovereign cannot be arrested. ${ }^{39}$ Nor can the sovereign arrest a person. ${ }^{40}$

It would seem appropriate to preserve these immunities - save that it would seem reasonable to limit the sovereign's criminal immunity to situations other than where life imprisonment can be imposed (in practice, the latter is (rather) unlikely to happen). Also,

- $\quad$ Arrest in a Royal Palace. On the rationale of the pre-eminence of the sovereign, it was said that no arrest can be made in a royal palace. ${ }^{41}$ However, the background to this should be noted. From early times, a court exercised jurisdiction over criminal offences within a royal palace and its verge (i.e. its geographical bounds). Further, court servants - as a form of privilege in serving the sovereign and (so as not to disrupt Crown business) - were accorded (it seems from Tudor times) some degree of immunity from arrest for civil matters, save where a senior court official (such as the Lord Chamberlain) gave permission. ${ }^{42}$ Today, the court of the verge (the palace court) no longer exists and the prospect of arrest for a civil offence in a royal palace is very rare. Also, privilege from arrest in a royal palace is outdated.$^{43}$ For example, if a member of staff is murdering people in a royal palace it would seem best for the police (or citizens making a citizen's arrest) to arrest the same, without needing to contact the Lord Chamberlain for permission. Thus, any Crown preorogative preventing the arrest of a person in a royal palace (whether the sovereign is residing there or not $)^{44}$ should be abolished as obsolete.

In conclusion, the criminal and civil immunity of the sovereign should be preserved (albeit, the former should exclude any crime which merits life imprisonment). Any prerogative preventing the arrest of a person in a royal palace should be abolished.

\section{LEGAL PRESUMPTIONS}

There are certain legal presumptions relating to the sovereign - and the Crown - which should be modernised or clarified. Thus,

- $\quad$ Minor. It is a common law presumption (fiction) that the sovereign cannot be a minor. ${ }^{45}$ However, such not only flies in the face of the factual position, it is no longer necessary since legislation provides for a regency, which is predicated on the fact that the sovereign can be a minor. Thus, this legal presumption should be dispensed with as unnecessary and inaccurate;

- Negligence. There is a legal presumption that the sovereign (whether in person or in the body politic) cannot be negligent. ${ }^{46}$ Rather, the same was always attributed to his/her officials and servants. This presumption should be preserved in respect of the sovereign in person since it is important to shield the sovereign from civil liability, in order to perform his/her office (see 5). However, this presumption was extended from the body natural to the body politic (i.e. not just to the sovereign in person but to the Crown in general). In modern times, caselaw has clarified that the Crown can be held liable for negligence and a Crown Act should confirm this;

\footnotetext{
${ }^{39}$ Chitty, n 13, p 374 'The dignity of the sovereign and the safety of the State, necessarily free the person of the king from liability to be arrested on any occasion'. Ibid, p 377 'the king cannot....arrest in person.'

${ }^{40}$ Justices of the Peace Act 1968, s 1(7)(now repealed) 'there is hereby abolished any power to commit to prison, or to issue warrants of arrest or search warrants, which may have been exercisable at common law by the sovereign in person, or by the privy council, members of the privy council or the secretary of state, whether or their or his own authority or on the special direction of the sovereign.' See also Halsbury (5th ed), n 17, vol 20, para 183 and vol 29, para 61. Also, M1, p 10 (power of arrest).

${ }^{41}$ Chitty (writing in 1820), n 13, p 376 'no arrest can properly be made in the king's presence, or within the verge of the royal palace, except by an order of the Board of the Green Cloth, or unless the process issue out of the Palace Court. And all the royal palaces are sanctuaries for persons liable to be arrested; and no species of judicial process can be executed therein; if any thing in the shape of possession and royal appearance be kept up, though the king do not at the time personally reside there.'

${ }^{42}$ Ibid, p 374 'in order that the king may not be exposed to inconvenience, and as a mark of that respect towards him which the law invariably incalculates, on sound principles of public policy, none of his majesty's household or menial servants or officers, bona fide substantially and continually employed, in waiting or attending on the royal person, can be arrested or taken in execution in civil actions, without notice first given to, and leave obtained from, the Lord Chamberlain of his majesty's household. This is the prerogative of the king: it is an important freedom from the full operation of the laws, which was instituted, not for the benefit of the servant, but for the convenience of the sovereign.' ${ }^{43}$ See also Halsbury (5th ed), n 17, vol 29, pp 61-2.

${ }^{44}$ Chitty (writing in 1820), n 13, p 376 stated 'no arrest can properly be made in the king's presence.' However, this, also, appears to be a touch absurd. If a person is attacking the sovereign (or those accompanying her) it would seem wise to arrest the same. Also, 'arrest' is not the same as restraining a person. The sovereign should be able to do the latter. Not least, if his (or her) own life is at stake.

${ }^{45} \mathrm{Ibid}$, 'the law cannot presume indiscretion or imbecility in the king, however young, his being under 21 years of age does not avoid his acts, and his non-age does in no case operate as a disability.' Coke, $\mathrm{n} 10$, vol 1, 43b (s 57) 'in judgment of law the king, as king, cannot be said to be a minor.'

${ }^{46} \mathrm{Ibid}, \mathrm{p} 379$ 'nor is there any reason that the king should suffer by the negligence of his officers, or by their compacts or combination with the adverse party.'
} 
- $\quad$ Laches. There is a common law maxim that 'time does not run against the sovereign' (nullum tempus occurrit regi). This should be preserved in the case of the sovereign as part of his personal immunity from civil liability ${ }^{47}$ as well as in respect of the Crown generally.

In conclusion, the legal fiction that the sovereign cannot be a minor should be dispensed with. Further, the Crown should not have immunity from negligence. However, both should not be liable for laches.

\section{LEGAL LIMITATIONS}

There are certain legal limitations relating to the sovereign - and the Crown - which should be modernised. Thus:

- $\quad$ Limitation - Trustee or Executor. There is a common law restriction on the sovereign being a trustee or executor (although this was not wholly observed in practice, albeit the sovereign - invariably - ordered others to act in his/her behalf). ${ }^{48}$ Such can be abolished;

- $\quad$ Limitation - Joint Tenant \& Tenancy in Common with a Subject. There is a common law presumption that the sovereign cannot be a joint tenant with a subject in the case of real or personal property. ${ }^{49}$ The rationale for this is that the sovereign is of such a eminent rank that any joint tenancy is overawed (i.e. wiped out) by the title of the sovereign. Today, such should be abolished (not least, because arbitrarily taking away a person's ownership in property would conflict with human rights). It seems this limitation may also have applied to the sovereign in the body politic. Thus, any limitation should be abolished in respect of both, ex abundante cautela. Also, to avoid uncertainty, the same should apply to any limitation in respect of a tenancy in common (it is unclear whether such a limitation exists). In short, these limitations should be dispensed with and the general law apply;

- $\quad$ Limitation - Reserving Rent. It is a common law presumption that the sovereign cannot reserve (i.e. alienate) rent; albeit the reason for this is rather obscure. ${ }^{50}$ This would (originally) have applied to the Crown since the sovereign (it was thought) could not hold real property in person. Today, such can be abolished - both in respect of the body politic and personally;

- $\quad$ Limitation - Ability to Franchise. Generally, the sovereign franchised (i.e. sold) many of its prerogatives in order to raise money. Common recipients were the duchies of Cornwall and Lancaster. Also, the counties palatine, the City of London, boroughs and lords of the manor. These occurred mainly in medieval times, when the franchise was worth something and where legislation did not otherwise cover the field. For example, the Crown, often, franchised its right to hold a fair (and charge a toll) as well as to operate a ferry etc. However, the common law (for obvious reasons) prohibited the Crown from franchising its right, inter alia, to: (a) summon (or dissolve or prorogue) Parliament; (b) assent to an Act of Parliament; (c) appoint a judge; (d) issue a pardon; ${ }^{51}$ (e) naturalise a person. ${ }^{52} \mathrm{~A}$ Crown Act should make provision for this. Further, the intent should be that - in the end - all Crown prerogatives become statutory (of which there are few). And, that no Crown prerogatives should be capable of being franchised;

\footnotetext{
${ }^{47}$ Bacon, n 12, vol 4 (1798), p 562 'From the presumption that the king is daily employed in the weighty and publick affairs of government, it hath become an established rule at common law, that no laches shall be imputed to him, nor is he any way to suffer in his interests, which are certain and permanent; and this his privilege quod nullum tempus occurrit regi, [time does not run against the king] has been confirmed by the statute de praerogativa regis.' 'Laches' (the term is law french) implies idleness or slackness, see JH Baker, Manual of Law French (2nd ed, 1900)(laches). See also Chitty, n 13, p 379 'From the earliest periods of English law, it has...been a maxim that nullum tempus occurrit regi; a maxim grounded on the principle that no laches can be imputed to the sovereign, whose time and attention are supposed to be occupied by the cares of government (ardua regni pro bono publico)'.

${ }^{48}$ See generally, M9, pp 304-6. Chitty (writing in 1820), n 13, pp 378-9 'The king may...hold as a trustee of lands, though he cannot be compelled to execute the trust...The king may also be appointed an executor; but as it cannot be presumed that he has sufficient time and leisure to engage in a private concern, the law allows him to nominate such persons as he shall think proper to take upon them the execution of the trust, against whom all persons may bring their actions; also, the king may appoint others to take the accounts of such executors.'

${ }^{49}$ This, pre-1800, applied to personal property since it was not thought that the sovereign could hold real property personally. See generally, M9, pp 287-92. Chitty, n 13, p 381 'It is ... an established principle, that where the king's right and that of a subject meet at one and the same time, the king's shall be preferred. Detur digniori is the rule in the case of a concurrence of titles between the king and subject. This rule has been already explained, as it regards debts and remedies in the case of the king... On the same principle, the king cannot be a joint tenant etc with a subject.'

${ }^{50}$ See generally, M9, pp 306-7.

${ }^{51}$ Chitty (writing in 1820), n 13, p 90 'It is an incommunicable prerogative; except, perhaps, in the colonies, where, by grant from the Crown, it may be exercised by the governor etc.'.

${ }^{52}$ Ibid, pp 118-9 'The jura coronae or rights of the Crown, so long as they are attached to the king, are called prerogatives; but when such prerogatives are delegated to a subject, they acquire the appellation of franchise; for all franchises are derived from the king. A franchise is defined to be a royal privilege or branch of the royal prerogative in the hands of a subject, by grant from the king.' See also Halsbury, n 17 (5th ed), vol 20, para 66.
} 
- Limitation - Minister of the Crown/Holding a Crown Office. A distance has always been maintained between the pre-eminent office of the sovereign and Crown offices. Thus, the sovereign cannot act as a minister of the Crown. Nor, hold a Crown office. ${ }^{53}$ Nor attend, or sit, in Cabinet. ${ }^{54}$ Such limitations should continue to apply;

- Limitation - Giving Evidence in his Own Cause. As a mark of his dignity, it has been said that the sovereign cannot give evidence in a court (i.e. oral testimony) in his own cause. ${ }^{55}$ However, this would not seem to prevent the sovereign giving written evidence as to facts within his knowledge in a civil case between subjects. ${ }^{56}$

In conclusion, limitations on the sovereign being a trustee or executor-as well as in respect of being a joint tenant or a tenant in common or reserving rent - should be abolished. However, the prohibition on the Crown franchising certain prerogatives should be retained. Also, the sovereign should be prohibited from: (i) being a minister of the Crown; (ii) holding a Crown office; (iii) attending (or sitting in Cabinet); or (iv) giving evidence in court in his (or her) own cause.

\section{CROWN PREROGATIVES}

The are a multitude of Crown prerogatives that apply to the Crown (whether to the sovereign in a personal capacity or in a public capacity, or both). A large number of these are obsolete. These are now considered. However, from the outset, it should be noted that Crown prerogatives were limited to the Crown - unless franchised pursuant to a charter. Thus - with exceptions - Crown prerogatives were not given to any of the following at common law:

- a consort of the sovereign;

- the heir(ess) apparent to the throne (and any consort of the same);

- a queen dowager;

- a princess royal;

- $\quad$ any member of the Royal Family, except the sovereign. ${ }^{57}$

The few exceptions related to: (a) a consort of the sovereign; ${ }^{58}$ (b) a queen dowager. ${ }^{59}$ However, these exceptions are now obsolete or unnecessary. Thus, a Crown Act should abolish any Crown prerogative accorded to (a) or (b). As for Crown prerogatives, since these tend to fall in distinct categories they may be analysed as such:

\section{(a) Military Prerogatives}

From early times, the Crown had a prerogative to the following, to:

- $\quad$ billet any member of the armed forces on the general public;

$(\text { obsolete })^{60}$

- impose martial law (including the jurisdiction of courts martial) on civilians;

- $\quad$ impress civilian subjects for military (i.e. naval and army) service;

$(\mathrm{L})^{62}$

\footnotetext{
${ }^{53} \mathrm{Ibid}, \mathrm{p} 377$. Ibid, p 80 'With respect to public offices merely of a ministerial nature...his majesty cannot execute them himself...'

${ }^{54}$ The sovereign used to 'attend' Cabinet, to hear discussions and make observations. Also, to 'sit' (i.e. direct proceedings). However, this has not been exercised since (it seems) 1781 - in the reign of George III (1760-1820) - and, under the doctrine of the separation of powers, neither Crown prerogative would be appropriate today. Thus, provision should be made for abolishing any such prerogative.

${ }^{55}$ Ibid, 'the king shall not give evidence in his own cause.'

${ }^{56}$ Ibid. James I (1603-25) gave a signed certifícate of promises made to a subject (Lord Clifford). This was allowed as proof in a court hearing. See Chitty (writing in 1820), n 13, p 378.

${ }^{57}$ In particular, Chitty notes, n 13, pp 404-5 'The prince [i.e. eldest son of the sovereign and heir apparent] has no other specific privileges over the rest of the royal children...'. See also Halsbury, n 17 (1st ed), vol 6, pp 366-70.

${ }^{58}$ Chitty, $\mathrm{n} 13$, pp 402-3 'In general, the queen consort is not exempted from laws operating on other subjects of the king; but in many instances the law has expressly granted her several immunities. Thus the Queen consort pays no toll; and cannot be amerced [fined], or arrested; nor is she obliged to find pledges de prosequendo; or bound by the Statute of Marlebridge [i.e. the Statute of Marlborough 1267], for driving a distress into another country... '. (those in italics are obsolete). Chitty noted that other prerogatives such as Queen's gold were obsolete ('long since fallen into decay'). It appears the consort is also: (a) entitled to her own courts and officers; (b) may be represented in court by her own Attorney-General and Solicitor General; (c) her writ does not abate as in the case of an ordinary person; (d) she cannot be made to give security by way of costs; (e) she can sue by way of information. (those in italics are obsolete). Halsbury, n 17, (1st ed), vol 6, para 366 (written in 1909), stated that the queen consort enjoys a separate ceremony on the coronation of the king which may be performed by the Archbishop of York. Today, such a prerogative may be dispensed with.

${ }^{59}$ Ibid, p 403 'Notwithstanding the death of the king, his consort, who thereby becomes the queen dowager, retains most of her privileges.'

${ }^{60}$ See generally, M3, pp 96-8. Also, M14, pp 55-7. See also Petition of Right 1627 (extant). Billeting was later, legislatively, provided for. However, billeting on the general public is long obsolete.

${ }^{61}$ Ibid, M3, pp 96-100. Also M14, pp 13-52.

${ }^{62}$ Ibid, M4, pp 18-20. Also, M14, pp 52- 55. This Crown prerogative was used to impress for the navy (and, in early times, seems to have been used for the army). A Royal Commisson report on Manning the Navy (1859) stated 'the system of naval impressments, as practised in former wars could not now be successfully enforced.' Impressment never applied to the air force, which was not created until the 20th century. See also Chitty (writing in 1820), n 13, pp 47- 8 .
} 
- $\quad$ issue letters of marque and reprisal;

$(\text { obsolete })^{63}$

- $\quad$ dig for saltpetre (for gunpowder);

(obsolete) ${ }^{64}$

- $\quad$ enter private land to dig for saltpetre;

$(\text { obsolete })^{65}$

- $\quad$ castellate (that is, to build a castle or fortified residence (a fort));

$(\text { obsolete })^{66}$

- $\quad$ erect military fortifications on private land;

$(\mathrm{L})^{67}$

- $\quad$ impose a toll for murage (to build city or town defensive walls).

$(\text { obsolete })^{68}$

Some of these prerogatives were franchised - such as that to impose a toll for murage. However, most (including the more important ones) were not. It is asserted that all of these Crown prerogatives should now be abolished since some are (manifestly) obsolete and others have been superceded by legislation (' $\mathbf{L}$ '). As to these prerogatives:

- $\quad \underline{B i l l e t}$. The common law right to billet army and navy personnel became statutory. Thus, any Crown prerogative is obsolete;

- Martial Law. The imposing of martial law (i.e military courts judging civilians according to military law) is now covered by the Civil Contingencies Act 2004 (which provides for civil courts). Thus, this Crown prerogative is obsolete;

- Impressment. The impressment of men for the navy (such became, effectively, limited to mariners aged between 18-55) became obsolete by 1815 . The right to impress men for the army (there was no right to impress for the air force) was always contentious and, in World Wars $1 \& 2$, statutory conscription was employed for the armed forces. Thus, this Crown prerogative is obsolete;

- $\quad$ Letters of Marque. The issue of letters of marque (also called letters of marque and reprisal) for privateering (as opposed to piracy) ended in 1856 (the Declaration of Paris 1856 renounced privateering). Thus, letters of marque are obsolete;

- $\quad$ Saltpetre. To dig for saltpetre (potassium nitrate, for gunpowder) - and to enter the land of subjects to do so became obsolete (in practice) by the $19^{\text {th }}$ century at the latest;

- $\quad$ Erecting Castles (Forts). Castellation is obsolete and planning permission would be needed in any case. Also, permission to retain weapons;

- $\quad$ Requisitioning Land. To requisition private land for military purposes is now governed by legislation;

- $\quad$ Toll for Murage. To impose a toll for murage (a toll levied to repair city and town walls for defensive purposes) ended (in practice) by the $15^{\text {th }}$ century at the latest, when the nature of warfare rendered defensive city and town walls obsolete.

In conclusion, these Crown prerogatives of a military nature should be abolished.

\section{(b) Animals \& Fish Prerogatives}

The sovereign still retains Crown prerogatives in respect of fish and swans. Thus:

- $\quad$ Roval Fish. Pursuant to the Act, Prerogativa Regis (c. 1273-4) - which is still extant - the sovereign has a prerogative to 'royal fish', which is generally taken to be a reference to sturgeon and whales (possibly, also, to porpoise, walrus, narwhals etc).$^{69}$ However, in 1971, the sovereign indicated that she no longer wished to retain the prerogative to royal fish; ${ }^{70}$

\footnotetext{
${ }^{63}$ Ibid, M4, pp 20-3. See also Chitty (writing in 1820), n 13, pp 40-3.

${ }^{64} \mathrm{Ibid}, \mathbf{M 4}$, pp 35-6. See also Chitty (writing in 1820), n 13, p 49.

${ }^{65}$ Ibid.

${ }^{66}$ See generally, M1, pp 34-8. The medieval castle (fortified residence) was obsolete by the end of the medieval ages, due to military developments.

${ }^{67}$ This was superceded by legislation in Victorian times. Military fortifications, in earlier times, comprised bulwarks (i.e. ramparts, often using gravel) and trenches. It was argued that, in war time, for the public good anyone could enter another's land to erect such (see M1, p 36). However, the caselaw for this (one in 1468) is little more than a dictum of Kingsmill JCP supporting the idea of an implied franchise by the Crown of its prerogative to erect fortifications on the land of a subject, without consent, in war time. See also Chitty, n 13, p 45 'the king is solely entitled to erect, fortify, and govern forts and other places of strength, within his dominions.' Ibid, p 49.

${ }^{68}$ See generally, M5, pp 68-76.

${ }^{69}$ See generally, M2, pp 548-51. Also, M8, p 24. This is a very old prerogative that William I (1066-87) may have brought with him from the law of Normandy. Alternatively, it may be even earlier, deriving from Viking law. Mention in English law occurs as early as the reign of Henry II (1154-89). See also Chitty (writing in 1820), n 13, p 144.

${ }^{70}$ See also M8, p 24.
} 
- $\quad$ Wild Swans. The sovereign also has a prerogative to wild, unmarked, swans on the sea (or the branches thereof). The purpose was for food - young swans (cygnets) being a delicacy. However, in practice, this is now limited to the Thames - of which there are 3 franchises extant - to the (i) Company of Vintners; (ii) Company of Dyers; and (iii) the Ilchester family (for a swan breeding colony at Abbotsbury in Dorset). ${ }^{71}$

In conclusion, the Crown prerogative to royal fish should be abolished. So too, in respect of royal swans (or, the latter should be limited to the Thames).

\section{(c) Mining Prerogatives}

It has been asserted that the Crown has a prerogative to gold and silver mines ('royal mines') within the sovereign's dominions. This prerogative was, sometimes, franchised. The basis, and rationale, for this prerogative has always been rather flimsy, being founded on a Tudor case, The Case of the Mines $(1567)^{72}$ in which counsel argued that the sovereign had such a right since:

- $\quad$ gold and silver were excellent and the sovereign was entitled to excellent things;

- the sovereign required gold and silver to fund an army, in order to protect the country;

- the sovereign required gold and silver for coinage;

- if a subject had gold and silver mines he could surpass the sovereign in wealth. ${ }^{73}$

These grounds have no merit today (even if they did in 1567). Further, the sovereign in person receives no financial benefit from royal mines. And, any financial benefit to the Crown (i.e. the sovereign in the body politic) is very low. Thus, such a prerogative should be abolished.

In conclusion, any Crown prerogative relating to royal mines (and any franchise) should be abolished.

\section{(d) Commercial Prerogatives}

There are a number of Crown prerogatives which are of a commercial nature. These comprise the following, the prerogative of the Crown (and any franchisee, where applicable) to:

- treasure trove ${ }^{74}$

- $\quad$ dig for treasure trove on private land: $;^{75}$

- $\quad$ wreck (as well as flotsam, jetsam and ligan), ${ }^{76}$

- $\quad$ create or dissolve a chartered corporation; ${ }^{77}$

- $\quad$ amend the charter of a chartered corporation; $;^{78}$

- confer a power on a chartered corporation to make byelaws $;{ }^{79}$

- $\quad$ operate markets and fairs; ${ }^{80}$

- $\quad$ operate ferries; ${ }^{81}$

- $\quad$ charge any customary rate or toll; 82

\footnotetext{
${ }^{71}$ See M5, pp 80-3. Also, Chitty (writing in 1820), n 13, pp 144-5.

${ }^{72}$ See generally, M3, pp 100-3. Also, Chitty (writing in 1820), n 13, pp 145-6.

${ }^{73}$ Ibid, p 100-1.

${ }^{74}$ See generally, M8, pp 16-22. Treasure trove is now regulated by the Treasure Act 1996. Franchisees comprise the duchy of Lancaster (which is in right of the Crown), the duchy of Cornwall (which, sometimes, chooses not to claim it), the City of London (this would only apply to the Square Mile, however) and, possibly, the City of Bristol (however, this would only apply to a very limited area of old Bristol town).

${ }^{75}$ Ibid, pp 22-3.

${ }^{76}$ See generally, M15, pp 308-12. See also Chitty (writing in 1820), pp 148-51.

${ }^{77}$ See Chitty, n 13, pp 120-33 (for dissolution, see pp 132-3). Corporations comprise: (a) corporations sole; (b) corporations aggregate, whether ecclesiastical (i.e. the Church of England) or lay.

${ }^{78}$ See also Halsbury (5th ed), n 17, vol 20, para 167, n 12.

${ }^{79}$ See also Enterprise and Regulatory Reform Act 2013, s 96 (royal charters: requirements for Parliamentary approval) 'Where a body is established by royal charter after 1 March 2013 with functions relating to the carrying on of an industry, no recommendation may be made to $[\mathrm{HM}]$ in council to amend the body's charter or dissolve the body unless any requirements included in the charter on the date it is granted for Parliament to approve the amendment or dissolution have been met.'

${ }^{80}$ See generally, M15, pp 277-90. Also, Chitty (writing in 1820), n 13, pp 193-6. Ibid, p 193 'As protector of commerce, the king alone possesses the power of creating markets and fairs; nor can anyone claim them but by grant from the Crown or by prescription...'

${ }^{81}$ See generally, M15, pp 301-6.

${ }^{82}$ Ibid, M5 (pontage and murage) and M9, pp 296-301.
} 
- $\quad$ regulate weights and measures; $;^{83}$

- $\quad$ license a commercial monopoly; ${ }^{84}$

- grant a patent for any invention. ${ }^{85}$

As to these:

- $\quad$ Treasure Trove. Treasure trove at common law has been superceded by the Treasure Act 1996. Further, the number of franchisees availing themselves of the franchise of the same is now very limited (in any case, the dukes of Cornwall and of Lancaster (i.e. the Queen) do not retain treasure trove in person);

- $\quad$ Wreck etc. In the case of flotsam, jetsam and ligan etc, the benefits of such, today, are so minor, that they are not of interest to the Crown or franchisees. Thus, this common law Crown prerogative should be abolished (as well as any franchise) ${ }^{86}$ In the case of wreck, the right is statutory (Merchant Shipping Act 1995, s 241). Thus, the common law prerogative should be abolished. As for any franchise of wreck, the position is the same as that of flotsam etc. It should be abolished (the only franchisees of wreck, in any case, likely to have any interest in the same today are the duchies of Lancaster and Cornwall);

- $\quad$ Chartered Corporations. The Crown may create a chartered corporation (or amend the charter of one). Also, it may grant power to a chartered corporation to amend its byelaws. It may also dissolve a chartered corporation. ${ }^{87}$ These powers should now be regulated by legislation (by a SI). Not least, in that such matters should, now, be subject to Parliamentary inspection and control;

- Markets \& Fairs. In medieval times, it was common for the Crown to establish and operate markets and fairs - as well as to franchise the same. ${ }^{88}$ A separate power could also be given to impose a variety of market related tolls (such as stallage, pickage etc). ${ }^{89}$ However, from Victorian times (if not earlier), this prerogative was superceded by legislation which was more detailed (and expansive) in respect of the hours and conditions as to the operation of the market;

- Domestic Ferries. As with markets and fairs - from an early time - the Crown claimed a prerogative to regulate public ferries (i.e. those providing passage for the general public, not private ferries).$^{90}$ Today, there are few domestic ferries operating - bridges having replaced the same. And, all (if not, almost all) ferries are now regulated by legislation ${ }^{91}$ - which is appropriate, since ferries comprise a form of monopoly. Thus, this Crown prerogative (and any franchise) should be abolished;

- $\quad$ Customary Rates \& Tolls. As a form of local tax, the Crown levied tolls and customary rates (charges imposed by way of a long-standing local custom) for things such as: (a) the operation of markets and fairs, ${ }^{92}$ (b) the operation of ports and harbours; (c) the maintenance of roads, streets (such as pavage, to pave the road) and bridges (the toll was called pontage); (d) the pasturing of animals. ${ }^{93}$ All common law customary rates and tolls have now been replaced by legislation or contract. Thus, they should be abolished;

- $\quad$ Weights \& Measures. From an early time (indeed, Anglo-Saxon times) the Crown regulated weights and measures. Especially, the accuracy and standardisation of the same. Today, legislation has now taken over in this area; ${ }^{94}$

- Monopolies. The Crown asserted that it had a prerogative to create (by way of license) commercial monopolies. Such was much abused in the times of Elizabeth I (1558-1603) and James I (1603-25) ${ }^{95}$ when they frequently sought

\footnotetext{
${ }^{83}$ See Chitty (writing in 1820), n 13, p 196.

${ }^{84}$ Ibid, p 177.

${ }^{85}$ Ibid, pp 176-93,

${ }^{86}$ If thought apposite, the Merchant Shipping Act 1995, s 241 should be amended to include flotsam, jetsam and ligan as well as wreck.

${ }^{87}$ See Halsbury (5th ed), n 17, vol 20, para 167, n 12. See also Enterprise and Regulatory Reform Act 2013 , s 96.

${ }^{88}$ See generally, M15, pp 277-90. Also (for tolls), M9, pp 296-301. Indeed, the control of markets goes back to Anglo-Saxon times. They could only held in fortified towns, for safety, see GS McBain, The Strange Death of the Law Merchant [2016] International Law Research, vol 5, no 1, pp 36-45, 66-74.

${ }^{89}$ For common market tolls such as stallage, pickage, tronage, scavage and lastage, see M9, pp 297-8.

${ }^{90}$ See generally, M15, pp 301-6.

${ }^{91}$ The Department for Transport (DfT) will have details.

92 See also Chitty (writing in 1820), n 13, pp 194-6.

${ }^{93}$ See M9, pp 296-301.

${ }^{94}$ Chitty, n 13, p 196 'The regulation of weights and measures, is ranked by Sir William Blackstone among the rights of the Crown; but... with some degree of impropriety: for, from Magna Carta to the present time, there are above twenty Acts of Parliament to fix and establish the standard and uniformity of weights and measures.'

95 James sought, among other things, to create monopolies in respect of: (a) the operation of hotels (inns); (b) gold and silver thread; and (c) the paying of recognizances for alehouses (i.e. deposits for good behaviour). There was an outcry and the franchisees of such were usually
} 
to create commnercial monopolies as a revenue raising exercise. ${ }^{96}$ This prerogative, however, was generally thought to be contrary to the common law and was declared to be such by the Statute of Monopolies 1623 (extant). Today, any power to create (or maintain) a monopoly should be legislative. Thus, a Crown prerogative to create any commercial monopoly should be abolished (it may, also, be noted that the Statute of Monopolies 1623 can be repealed as spent);

- $\quad \underline{\text { Patents. }}$. The Crown asserted a power to grant patents for inventions. ${ }^{97}$ Today, it is appropriate that legislation wholly regulates such matters.

The rationale for the Crown undertaking all the above was that these were 'money spinners' both for the Crown in general and, more particularly, the sovereign. Such was prior to 1760 when the sovereign was not funded by the State by means of a Civil List. Today, this rationale has long gone. Thus, legislation should now regulate such matters in their entirety.

In conclusion, all Crown prerogatives of a commercial nature should be abolished. Such should now be regulated by legislation.

\section{(e) Border Prerogatives}

There are a number of Crown prerogatives which relate to the control by the Crown of the nation's borders (these were not franchised, being of primary importance to the Crown). These comprise the prerogative of the Crown to:

- $\quad$ issue letters of safe conduct; 98

- $\quad$ prohibit subjects from leaving the realm (including by means of the writ ne exeat regno); ${ }^{99}$

- $\quad$ order subjects to return to the realm. ${ }^{100}$

All of these prerogatives are now obsolete. In respect of them:

- $\quad$ Letters of safe conduct. These were the precursor to the modern passport. They were issued to foreigners (and, in some cases, subjects) to enable them to reside and travel, in safety, in the realm for a limited period of time (usually 40 days or so). They existed from the time of Henry III (1216-72) and, likely, earlier. Foreign merchants were accorded an additional protection under a section in Magna Carta 1215 (now repealed). ${ }^{101}$ Over the course of time, letters of safe conduct were limited in their issue to subjects of nations at war with England (as noted in Calvin's Case in 1608). ${ }^{102}$ Letters of safe conduct are redundant today since they have been replaced by passports. And, during wartime, legislation has been used to deal with the entry and departure of foreigners - such as in the case of World War I (1914-8) and II (1939-45). Thus, letters of safe conduct are obsolete;

- Subjects entering and exiting the Realm. From early times the Crown asserted a prerogative to prevent British subjects from leaving the realm. Also, a prerogative to order a subject to return to the realm. ${ }^{103}$ Such prerogatives were a useful device for English sovereigns to deal with their enemies - especially, persons who might depart abroad to raise support to de-throne them (such as in the time of Elizabeth I (1558-1603). However, the ambits of these prerogatives were always uncertain and contentious in nature ${ }^{104}$ and - after the Glorious Revolution of 1688 - they

\footnotetext{
impeached by Parliament in an effort to suppress these monopolies. See GS McBain, Abolishing High Crimes and Misdemeanours and the Criminal Processes of Impeachment and Attainder (2011) 85 ALJ 810-79, at pp 824 and 832.

${ }^{96}$ Chitty, n 13, p 177 'it was, in the most antient times, a rule of the common law, that a monopoly [which may be defined to be an allowance by the king to any person or body of persons, for the sole making or selling etc any thing whereby any persons are sought to be restrained of a freedom or liberty they had before, or are hindered in their lawful trade] is contrary to law. These monopolies were granted by Queen Elizabeth [1558-1603], to an intent highly prejudicial to the public, for the purpose of filling her coffers; but the mischief was suppressed by the statute 21 James I c 3 [Statute of Monopolies 1623] which declares, that all monopolies etc are contrary to law, and shall be deemed void and of none effect; and some provisions are made for the prevention of any future grants tending to create a monopoly.'

${ }^{97}$ Ibid, pp 177-93.

${ }^{98}$ See generally, M4, pp 23-6. See also Chitty (writing in 1820), n 13, pp 48-9 '[HM] may...permit an enemy to come into the country without molestation, by granting him letters of safe-conduct. These letters ought to be under the great seal, and inrolled in chancery. But passports under the king's sign manual or licences from his ambassadors are now more usually obtained, and are allowed to be of equal validity.'

${ }^{99}$ See Chitty, n 13, p 21-4

${ }^{100} \mathrm{Ibid}, \mathrm{p} 24$

${ }^{101}$ Magna Carta, ch 30. See Chitty, n 13, p 49

${ }^{102}$ See Chitty, n 13, p 24.

${ }^{103}$ The basis of this would have been - at least, from the time of William I (1066-87) - that a subject owed allegiance to the Crown, due to his having given an oath of homage or of fealty (whether directly or indirectly) to the Crown. The basis of allegiance was that a person pledged not to undertake acts that might aid the king's enemies (this being, in wartime, high treason).

${ }^{104}$ At common law, the position appears to have been (and still is) that English subjects can freely enter and exit the realm. Legislation in war time may qualify or override this. During the reigns of the Plantagenets, in war time or national emergency, at times (such as in 1317, 1329 and 1350) there was a blanket prohibition on subjects leaving the realm (see e.g. M4, p 27, fns $99 \& 100$ ). However, by the time of the Tudors, prohibitions were limited to specific individuals.
} 
appear to have been never (or scarcely) been used. Today, such prerogatives are an encroachment on human rights ${ }^{105}$ and specific legislation should be required. In any case, these prerogatives are regarded as obsolete. ${ }^{106}$

In conclusion, the above Crown prerogatives are obsolete and should be abolished.

\section{(f) Prison Prerogatives}

From early times, ${ }^{107}$ the Crown asserted prerogatives relating to the establishment (and operation) of prisons. These comprised the prerogative of the Crown to:

- $\quad$ establish a new prison;

- operate a prison;

- franchise the operation of a prison. ${ }^{108}$

The franchising of the operation of a prison, in earlier times, was common as a revenue raising device. However, many abuses were committed by the gaolers starving, extrorting or torturing prisoners, such that franchises by the Crown were no longer granted ${ }^{109}$ (albeit, technically, the Crown still retains the power to franchise prisons). Today, prisons in the UK exist and operate under legislation and they are regulated by a specific Government department (the Home Office). These prerogative powers, therefore, are no longer required (nor that to franchise).

In conclusion, all Crown prerogatives relating to prisons should be abolished.

\section{(g) Coinage Prerogatives}

There are a number of Crown prerogatives which relate to the control by the Crown of the coin of the realm. Thus, the Crown (and franchisees) has a prerogative to:

- $\quad$ issue (that is, mint) coin of the realm and to fix its denomination (i.e. value) and render it current;

- legitimate foreign coin;

- decry coin of the realm, making it no longer current. ${ }^{110}$

From Anglo-Saxon times, sovereigns issued coinage bearing their image and they regulated the locations in England where mints could be established (it was a capital offence to mint coins otherwise). ${ }^{111}$ They also franchised the right to mint coins (such franchises died out in later times). Further, given the scarcity of coinage on many occasions, sovereigns permitted the circulation of foreign coins in the realm - with their being treated with the same legitimacy as coins of the realm. ${ }^{12}$ Today, legislation governs coinage - which is appropriate since Parliament should oversight, and regulate, such matters.

In conclusion, all Crown prerogatives relating to coinage should be abolished.

\section{(h) Printing Prerogatives}

Printing commenced in England c. 1476. The Crown sought to control the same for two reasons. It feared the dissemination of seditious - or religiously inflammable - material. It also saw the potential for making money by taking a monopoly over the publication of certain books. The prerogative of the Crown in the case of the latter was especially asserted in the time of James

\footnotetext{
${ }^{105}$ It may be noted that there was no pre-requisite that a British subject had committed (or been charged with) a crime.

${ }^{106}$ See M4, p 30 (fns 121, 123).

${ }^{107}$ For prisons in early times, see GS McBain, False Imprisonment and Refusing to Assist a Police Officer - The Need for Statutory Offences (2015) Journal of Politics and Law, pp 51-99. Also, GS McBain, Modernising the Law on Escape, Prison Breach and Rescue (2014) Review of European Studies, vol 6, no 4, pp 147-173. See also Halsbury, n 17 (1st ed), vol 6, p 408.

${ }^{108}$ Chitty (writing in 1820), n 13, p 103 'Prisons being places of a public description, and connected with the execution of justice, are in general the property of the king. And it seems that by the common law his majesty is impliedly their governor; though by various statutes, the custody of goals, except such as are the legal property or franchise of a subject, is vested in the sheriffs of the different countries. His majesty cannot, therefore, now grant the custody of prisoners to prívate persons. The formation of a new prison can be legally effected only by the authority of Parliament.'

${ }^{109}$ By 1883, all prison franchises had ended, see McBain, n 107 (first article), p 70. See also Halsbury (1st ed, 1909), n 17, vol 6, p 408.

${ }^{110}$ Chitty (writing in 1820), n 13, p 196 'As the regulator and protector of commerce, of which money is the medium, the king alone is entrusted with the right to coin money, to fix its denomination or value, and to render it current. His majesty may legitímate foreign coin, and make it current here, declaring at what value it shall be taken in payment, and may, at any time, decry any coin of the kingdom, and make it no longer current.' Ibid, p 199 'No proclamation seems necessary to the legitimation of money coined by the royal authority in this country, unless unusual pieces be coined; but such proclamation is essential to the legitimation of foreign coin made current here.'

${ }^{111}$ See generally, GS McBain, Abolishing the Doctrine of Consideration (2018) International Law Research, vol 7, pp 34-6 (in Anglo-Saxon times) and Appendix A to the same.

${ }^{112}$ See McBain, $\mathrm{n} 111$ above.
} 
I (1603-25). However, the courts were reluctant to permit any Crown prerogative to extend widely to printed books - with the result that the precise ambits of this prerogative have always been uncertain. ${ }^{113}$

- In modern times, legal texts (usually) assert that any Crown monopoly is limited to: (a) certain works issued by the Church of England (CoE); and (b) State papers; ${ }^{114}$

- Today, given modern human rights legislation in respect of freedom of speech, it is important that there be no general Crown monopoly over the printing of books. And, that any franchise should be limited to certain authorised works of the CoE and State papers (simply to ensure their accuracy). Indeed, one would question whether any State copyright should not now be abolished in the case of $\mathrm{CoE}$ works and that the CoE have the copyright to the same. In any case, any Crown copyright should now be specified in legislation.

In conclusion, the prerogative of the Crown to have a sole right (that is, a monopoly) to print any book should be abolished and any such right should - if still thought to be essential - be set out in legislation (such as the Copyright, Design and Patents Act 1988).

\section{(i) Prerogatives concerning the Sea}

From early times, the Crown sought to control various aspects relating to the sea. Thus, there was a Crown prerogative to:

- $\quad$ establish public ports and harbours (havens), ${ }^{115}$

- $\quad$ regulate public ports and harbours (havens); ${ }^{116}$

- $\quad$ charge for services in respect of public ports and harbours (havens); ${ }^{117}$

- $\quad$ erect lighthouses (and beacons) as sea marks - including on the land of a subject without consent. ${ }^{118}$

In part, this reflected the desire of the Crown to control the sea borders of the realm and, thus, to control the entry - and exit of foreigners. Also, to repel enemies. There was, also, a revenue raising aspect - in that revenue could be gained from controlling the import and export of goods. Further, there was a desire by the Crown to prevent persons (whether British subjects or foreigners) surreptitiously taking (gold and silver) coinage out of the realm, with a result that the treasury was depleted. Finally, the Crown sought to prevent its enemies fleeing abroad (save where it permitted the same) as well as British subjects departing abroad to fight as mercenaries against countries with which it had amicable relations.

- For all these reasons, from early times, the Crown closely regulated ports and harbours - specifying which British subjects and foreigners might arrive and depart, as well as in respect of the entry (and exit) of goods. In the case of the latter, customs officers supervised the same and imposed customs and excise duties;

- Today, it is appropriate that legislation should regulate all the above. Thus, from Victorian times, legislation has regulated the establishment of public ports (and harbours) as well as their operation and the imposition of charges (i.e. charges for ships using the port as well as any customs duties).

\footnotetext{
${ }^{113}$ Chitty (writing in 1820), n 13, pp 239-40 limited the Crown's prerogative to: (a) 'all Acts of Parliament, proclamations, and orders of council'. Also, (b) 'the publication of all liturgies and books of divine service etc.' Also, Chitty noted that the the Crown was said 'to have a right, by purchase, to the copies of such law books, grammars, and other compositions, as were compiled or translated at the expense of the Crown.' However, this opinion is not observed today.

${ }^{114}$ Halsbury (5th ed), n 17, vol 23, paras 507-8 notes that the Crown has a prerogative to exercise a monopoly in the printing of the authorised version of the Bible (i.e. the version approved by the $\mathrm{CoE}$ ) and the Book of Common Prayer (same). Also, to franchise the same. Acts of Parliament (and Measures of the CoE) are Crown copyright by virtue of the Copyright Designs and Patents Act 1988, s 164.

${ }^{115}$ See Chitty (writing in 1820), n 13, pp 174-5.

${ }^{116}$ Ibid.

${ }^{117} \mathrm{Ibid}, \mathrm{p} 174$ 'the right to erect ports and havens is in general exclusively vested in the Crown...[however] a subject may, by charter from the King, or prescription, erect a port...The king has not merely the prerogative power of erecting ports and havens, but he possesses prima facie the propriety or ownership in all the ports and havens within his dominions, though the public have a right to use them; and even though the right to a port or haven be vested by charter or prescription in a subject, yet he holds it charged or affected with the jus regium or royal prerogative, as it relates to ports and havens. The royal right of superintending ports and havens is a necessary consequence of the prerogative ownership in them. Hence the king is entrusted with the care of preventing and reforming public nuisances in ports and havens...But this superintending power does not in general extend so far as to enable the king to open and shut ports and havens for the purpose of prohibiting the importation or exportation of goods. Nor can arbitrary or excessive duties for cranage, wharfage etc be taken from the public; but the duties must be reasonable and moderate, though settled by the king's licence or charter.'

${ }^{118}$ Ibid, p 175, 'The king being entrusted with the safety of navigation, possesses also by the common law, the prerogative right of erecting beacons and lighthouses in such places as his wisdom may deem most convenient for the preservation of ships and mariners, and the general interests of his subjects. This royal right is considered so important to the public weal, that it will justify his majesty in erecting a beacon on the land of a subject without his consent. The right of erecting beacons and lighthouses is vested by the common law of the land exclusively in the king; and a subject cannot raise them without the king's permission.'
} 
- The Crown also regulated the erection of lighthouses and beacons, as sea marks - albeit, both are obsolete today in most instances, given modern means of sea navigation. ${ }^{119}$

In conclusion, the prerogative of the Crown to establish and regulate public ports and harbours (as well as any charges imposed at the same) should be abolished. So too, any prerogative to erect lighthouses and beacons. Legislation should now govern these matters.

\section{(j) Local Government Prerogatives}

There are a number of Crown prerogatives of a constitutional nature concerning the geographical administration of local government into: (i) counties; (ii) cities; (iii) boroughs; and (iv) towns. Thus, the Crown has a prerogative to:

- create a county palatine; ${ }^{120}$

- $\quad$ create a county corporate (or royal county corporate); ${ }^{121}$

- $\quad$ grant the status of a city; ${ }^{122}$

- $\quad$ grant the status of a borough (or royal borough); ${ }^{123}$

- $\quad$ grant the status of a town (or royal town). ${ }^{124}$

As to these:

(i) Counties Palatine. From, at least, the time of king Alfred the Great (AD 886-99), Anglo-Saxon England was divided into counties for the purpose of governing the same. Also, for military purposes, Alfred fortified certain towns with walls (such towns were called 'boroughs' or 'burghs') - in order to defend them from Viking invaders. ${ }^{125}$ Post-Conquest, there arose the concept of a county palatine. That is, where the landowner (invariably, an earl) was granted prerogative rights (jura regalia) as fully as those of the sovereign. Such was for military and legal purposes. ${ }^{126}$ Once, there were a number of counties palatine. ${ }^{127}$ Today, there are only 3 and they exist in name only viz.

- $\quad$ Chester. The county palatine of Chester re-vested in the Crown in 1830 when any jura regalia in respect of the same ended. This did not affect the courtesy title of Earl of Chester, which is reserved to the heir apparent to the throne. However, the same is no longer necessary and should be abolished; ${ }^{128}$

\footnotetext{
${ }^{119}$ Any prerogative to erect fortifications on the land of a suject without their consent should be subject to legislative compulsory acquisition.

${ }^{120}$ See generally, M5, pp 83-6. It may be noted that creating a county palatine resulted in a divestment of rights in respect of justice which would not be appropriate today, see Halsbury (5th ed), n 17, vol 29, para 66 'palatinate jurisdictions cannot be granted at the present day without the authority of an Act of Parliament.'

${ }^{121}$ Chitty (writing in 1820), n 13, p 119-20 'The counties palatine, Chester, Durham and Lancaster, the royal franchise of Ely...may be ranked among royal franchises, as they in general arose from the favour of the Crown to those particular districts wherein we find them erected.'

${ }^{122} \mathrm{Ibid}, \mathrm{p} 120$,'counties corporate; which are certain cities and towns...to which out of special grace and favor, the kings... have granted the privilege to be counties of themselves, and not to be comprized in any other county; but to be governed by their own sheriffs and other magistrates, so that no officers of the county at large have any power to intermeddle in therein. There is no doubt that the Crown possesses the power of granting to any city to have justices of their own within themselves, and may exclude by express words the county justices from intermeddling in the ordinary business of a justice of the peace.'

${ }^{123} \mathrm{H}$ Sweet, The Student's Dictionary of Anglo-Saxon (1896), 'burg, bur(u)h, pl byrig, burga f. fortified place; (fortified) town, city'. See also $\mathrm{J}$ Bosworth, Anglo-Saxon and English Dictionary (1868)(burh).

${ }^{124}$ See M15, p 300.

${ }^{125}$ London was already a walled town from Roman times (and, in Anglo-Saxon times, it was called 'Londonburgh'). London was also, as with so many towns, in Anglo-Saxon times, owned by the king, but in his body politic (that is, it was not owned by him privately and, thus, title to it could not pass from him by will). See generally, GS McBain, Liberties and Customs of the City of London - Are there any Left ? (2013) International Law Research, vol 2, no 1, pp 32-95.

${ }^{126}$ See M5, pp 83 \& 85. The position was much the same for those who guarded the Welsh marches (the marcher lords). They were accorded certain privileges (the Welsh marches no longer exist).

${ }^{127}$ They included those of Pembroke (abolished 1535), Hexham (abolished when united with Northumberland in 1572), Chester (its status ended in 1830), Durham and Lancaster. The Isle of Ely was not a county palatine (only a royal franchise, which ended in 1837). The Duchy of Cornwall is not a county palatine.

${ }^{128}$ Halsbury $\left(4^{\text {th }}\right.$ ed), n 17, vol 12(1), para 248 'This palatinate is now vested in the Crown, and the title of the Crown to foreshore there rests upon the title of the earls of Chester'. The latter statement is incorrect. Since William I (1066-87) laid claim to the ownership of all England (including the foreshore), any franchise of the same would have been by charter (or prescription). If the palatinate is abolished, any foreshore (in any case) will revert to the Crown. However, if Halsbury is correct, then, abolition of the title Earl of Chester will have the same effect since the Crown is lord paramount.
} 
- Durham. Today, the county palatine of Durham remains (but only in name) ${ }^{129}$ since it has the right to appoint an Attorney-General and a Solicitor-General (such being jura regalia - the franchise of these Crown offices). ${ }^{130}$ These offices are not necessary now;

- $\quad$ Lancaster. The duchy of Lancaster includes a county palatine. However, the name only remains since there are no jura regalia still exisiting in respect of it (the right of the duchy to appoint an Attorney-General is separate, being a right accorded to the duchy by the Crown, qua duchy, by patent). ${ }^{131}$

There is no need (or purpose) for the Crown having a prerogative to create a county palatine today. Further, it would not do so in practice. Thus, this right should be abolished. The counties palatine of Chester, Durham and Lancaster should, also, be abolished since they now exist in name only.

(ii) Counties, Boroughs, Towns \& Cities. Counties, boroughs and towns (as well as the title of a city) are descriptions employed for geographical governmental functions only and the epithet 'royal' (as in royal county, royal borough or royal town $)^{132}$ is a courtesy title today since it does not mean - as it did in times past - that the sovereign either owned the same (whether in the body personal or in the body politic) or that such can elect its own sheriffs and magistrates (JP's). ${ }^{133}$

Thus, the Crown's prerogative to create a county (or a royal county) - or the status of a city, a town or a borough (or a royal city, town or borough) - by charter should also end, as unnecessary. Perhaps, without prejudice to any royal counties, boroughs and towns still extant. ${ }^{134}$ Consideration should also be given to abolishing the term 'borough' since it no longer has meaning (town walls no longer exist for defensive purposes). ${ }^{135}$ The application of the term 'City' should, also, not be a Crown prerogative (it confers no specific legal rights in any case). In conclusion, all these geographical descriptions should be matters for the government to determine, pursuant to legislation.

In conclusion, Crown prerogatives to create counties (whether palatine or corporate) should be abolished. Also, the prerogative to grant the status of: a city, a borough (or royal borough) or a town (or royal town) should be abolished.

\section{(k) Prerogatives re Minors, the Mentally IIl \& Charities}

The Crown has prerogatives to supervise:

- the persons and estates of minors and the mentally ill; ${ }^{136}$

- $\quad$ any charity. ${ }^{137}$

As to these:

- Minors \& Mentally Ill. From early times, the Crown had the prerogative to supervise the persons (and estates) of minors ${ }^{138}$ and the mentally ill (formerly, termed 'idiots' and 'lunatics'). ${ }^{139}$ This was for their good (although not always so exercised) on the basis of the Crown being 'parens patriae' (the 'parent of the country'). ${ }^{140}$ However,

\footnotetext{
${ }^{129}$ See M5, p 84 See also the Durham County Palatine Act 1858. Holy Island was not transferred to the Crown. Two other exceptions appear to be spent, Ibid, p 84, n 138.

${ }^{130}$ All jura regalia were revested in the Crown in 1858 (with an exception now spent, see M5, p 84, n 137).

${ }^{131}$ See M12, p 15.

${ }^{132}$ Despite London being owned by the sovereign (in the body politic, see n 125) it was rarely called a 'royal town' or a 'royal city'. This was, likely, because Londoners were very independent having secured many privileges from the Crown even in Anglo-Saxon times (thus, William I termed them in a charter of c. 1067, 'buru waru' - viz. borough men, citizens of a fortified town) and not his personal retainers (such as in the case of the royal demesne (estate)). See McBain, n 125, p 4.

${ }^{133}$ Sheriffs meant high sheriffs when the same had legal powers. Now, the title of high sheriff is only a courtesy one.

${ }^{134}$ See M15, p 300. The only royal county appears to be Berkshire (where Windsor Castle is situated). There appear to be 7 royal boroughs presently existing (Greenwich, Kensington and Chelsea, Kingston on Thames, Leamington Spa, Tunbridge Wells, Windsor and Maidenhead, Wooton Bassett). Caernarfon in Wales has the status of a royal town.

${ }^{135}$ A benefit of this would be that all borough charters would, ipso facto, be cancelled. Thus, no detailed review of the same would be required.

${ }^{136}$ See generally M1, p 19. See also Chitty (writing in 1820), n 13, pp 155-60.

${ }^{137}$ Ibid. See also Chitty (writing in 1820), n 13, pp 161-2.

${ }^{138}$ Chitty (writing in 1820), n 13, pp 155-6 'The superintending power over infants was originally in the King by the common law, and was by his majesty delegated to the Lord Chancellor, who seems to exercise it as a branch of his general jurisdiction; and no separate commission is necessary to legalise the chancellor's jurisdiction in this respect.'

${ }^{139} \mathrm{Ibid}, \mathrm{p} 157$ 'The superintenance of idiots, who are persons devoid of understanding from their births, and are presumed never likely to attain any, is also vested in the king, not however it seems by the common law, but by statutes for the benefit of the subject on the party being found an idiot by a jury of twelve men on the old common law writ de idiota inquirendo.' Ibid, p 159 'The king is also guardian of lunatics; and his majesty's authority in this respect generally is and may be delegated to the Lord Chancellor or other person, in the same manner as that relative to idiots is delegated.'

${ }^{140} \mathrm{Ibid}, \mathrm{p} 155$ 'The king is in legal contemplation the guardian of his people; and in that amiable capacity is entitled, (or rather it is his majesty's duty, in return for the allegiance paid him) to take care of such of his subjects, as are legally unable, on account of mental incapacity, whether it proceed from 1st nonage: 2 idiocy: or 3 lunacy: to take proper care of themselves and their property.'
} 
such powers passed - in time - to the Lord Chancellor. Now, they are exercised by Government departments pursuant to legislation and by the courts - not by the Crown as such. ${ }^{141}$ Thus, any prerogative is otiose and should be abolished, being superceded by legislation;

- $\quad$ Charities. The Crown also has a prerogative to supervise charities -- the prerogative of visitation (supervision). However, such a proposition has been stated too widely ${ }^{142}$ and this prerogative only applies where a relevant Crown charter or legislation or the Court of Chancery or the Charities Commission has no supervisory status. It is asserted the latter two now cover all eventualities. Thus, this Crown prerogative is no longer required.

Provision for minors was also made in the Tenures Abolition 1660, s 8 (fathers may dispose of the custody of children during their minority except popish recusants. Actions of ravishment of ward for guardians). It provides:

where any person has or shall have any child or children under the age of [18 years] and not married at the time of his death that it shall and may be lawful to and for the father of such child or children,

whether born at the time of the decease of the father or at that time in ventre sa mere, or whether such father be within the age of [18 years] or of full age

by his deed executed in his life time, or by his last will and testament in writing in the presence of two or more credible witnesses in such manner and from time to time as he shall respectively think fit

to dispose of the custody and tuition of such child or children for and during such time as he or they shall respectively remain under the age of [21] years or any lesser time to any person or persons ${ }^{143}$ (spelling modernised, wording divided for ease of reference)

Today, a more appropriate age for the minor is under 16 years. Further, such should not occur if the mother is still alive. Also, the right of disposal should apply to a dying mother as well (but not if the father is alive). In short, this wording should be stated in a Crown Act as modernised, since it reflected the prerogative of the Crown as parens patriae to make provision for the same. Alternatively, it could be placed in family legislation dealing with minors.

In conclusion, these Crown prerogatives should be abolished as unnecessary.

\section{(l) Constitutional Prerogatives - Styles \& Titles}

Given the pre-eminence of the sovereign - in early times - they (unilaterally) accorded themselves titles as they thought fit. Legislation now deals with this (see Royal Titles Act 1953, see 1). However, the Crown has the sole prerogative to confer titles of honour, dignities and precedence. ${ }^{144}$ Such are conferred by:

- a grant (in the form of letters patent); or

- a writ of summons (in the case of peerages); or

- by corporeal investiture (in the case of knights).

Subject to certain restrictions, the sovereign cannot create any new title or dignity which does not exist before. However, she can confer any title (or precedence) on such of her subjects as she pleases. That said, where titles are conferred for Parliamentary (or other public) services, it is usual for the sovereign to be largely guided by the advice of the Prime Minister. In particular, the Crown had (and has) ${ }^{145}$ the prerogative to create:

- $\quad$ hereditary peerages - (i.e. duke, earl, marquess, viscount or baron) ${ }^{146}$

- $\quad$ life peerages (since 1958);

\footnotetext{
${ }^{141}$ See M1, p 19.

${ }_{142}$ As Chitty (writing in 1820), n 13, p 161 pointed out, Blackstone stated the prerogative too widely 'if there be a charter with proper powers, the charity must be regulated in the manner prescribed by the charter, and there is no ground for the controlling interposition of the Court of Chancery.'

${ }^{143}$ It continues (this wording is spent) :'in possession or remainder other than popish recusants, and that such disposition of the custody of such child or children made since the [24 Feb 1645] or hereafter to be made shall be good and effectual against all and every person or persons claiming the custody or tuition of such child or children as guardian in socage or otherwise; and that such person or persons to whom the custody of such child or children has been or shall be so disposed or devised as aforesaid shall and may maintaine an action of ravishment of ward or trespass against any person or persons which shall wrongfully take away or detain such child or children for the recovery of such child or children and shall and may recover damages for the same in the said action for the use and benefit of such child or children.'

${ }^{144}$ Chitty (writing in 1820), n 13, pp 107-8, 'The Crown alone...can create and confer dignities and honours. The king is not only the fountain; but the parent of them.' See also Halsbury ( $1^{\text {st }}$ ed), n 17, vol 6, pp 454-8.

${ }^{145}$ See Halsbury (5th ed), n 17, vol 29, para 55 'The Crown and its royal prerogative is the legal authority for the granting of all state honours and titles.'

${ }^{146}$ Chitty (writing in 1820), n 13, p 108 'The titles of nobility now in use are dukes, marquesses, earls, viscounts and barons'. Earls (eorls) and barons probably existed before the conquest. The title of 'duke' first arose in 1337 (Duke of Cornwall). The title of 'marquis' first arose in the reign of Richard II (1377-99). See generally, pp 108-18. See also G Jacob, Lex Constitutionis (1719), pp 76-90.
} 
- the title of lord mayor (or deputy lord mayor);

- the courtesy title of 'right honorable';

- the courtesy title of 'esquire'. ${ }^{147}$

In respect of these:

- $\quad$ Hereditary Peerages. These presently existing comprise the titles of: duke, marquess, earl, viscount and baron. Since 1958 , the creation of new hereditary peerages has been restricted to the royal family - although the prerogative of the Crown is not limited in this respect. Consideration should be given to the abolition of the prerogative to create new hereditary peerages - without prejudice to the continuation of those presently existing. In any case, a Crown Act should re-state the Peerage Act 1963;

- $\quad$ Life Peerages. These have been created since the Life Peerages Act 1958. A Crown Act could abolish the creation of any new ones ${ }^{148}$ - without prejudice to the continuation of those presently existing. Alternatively, it could not restrict the continuance of the same, but remove any right to sit in the House of Lords. However, these are political decisions. Also, the Life Peerages Act 1958, s 1 (power to create life peerages carrying right to sit in the House of Lords) should be re-stated in a Crown Act. It provides:

(1) $[\mathrm{HM}]$ shall have power by letters patent to confer on any person a peerage for life having the incidents specified in [ss] (2) of this [s]. (2) A peerage conferred under this [s] shall, during the life of the person on whom it is conferred, entitle him - (a) to rank as a baron under such style as may be appointed by the letters patent; and (b) subject to [ss](4) of this [s], to receive writs of summons to attend the House of Lords [HL] and sit and vote therein accordingly, and shall expire on his death.(3) A life peerage may be conferred under this [s]on a woman. (4) Nothing in this [s] shall enable any person to receive a writ of summons to attend the [HL], or to sit and vote in that House, at any time when disqualified therefor by law. ${ }^{149}$

- Lord Mayor. Such a title (the term is Anglo-Norman) came with the Normans and is not to be found in Anglo-Saxon times. London was, probably, one of the first towns to have a lord mayor. ${ }^{150}$ These lord mayors were appointed by, and responsible to, the Crown - something not occurring today. Thus, the election of a mayor (and deputy) should be left to town (and city) councillors to determine today, pursuant to legislation;

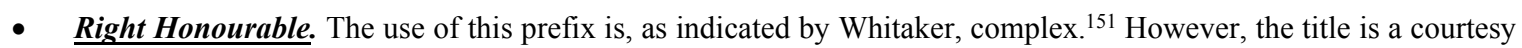
one. Not one granted to a specific individual by charter (including letters patent). Consideration should be given to its being dispensed with (the use of the word 'honourable' in Parliament results from Parliamentary custom and not, it seems, as a result of a Crown prerogative);

- $\quad$ Esquire. Originally, this prefix referred to one who carried the shield of a knight in battle. Then, it became used as a title of dignity to refer to a person next in degree below a knight. By 1727 the term had expanded to include: (a) all the younger sons of noblemen; (b) the eldest sons of (a) - and their eldest sons - successively; (c) the four esquires of the king's body; (d) those serving the sovereign in any worshipful calling (such as his surgeon, master cook etc); (e) those created esquires by the sovereign with the collar of SS of silver - such as heralds and sarjeants at arms; (f) the heads of some ancient families (this, by prescription); ( $\mathrm{g}$ ) those bearing any superior office - such as that of a high sheriff; (h) JP's; (i) barristers; (j) many wealthy men. Today, the title is used as a courtesy title and indiscriminately. Consideration should be given to its being abolished. ${ }^{152}$

Finally, it may be noted that old legislation relating to peerages viz. the

\footnotetext{
${ }^{147}$ Ibid, p 118 'The king possesses... the power of creating esquires, and therefore if the king by his commission, constituting a subject a magistrate or military officer etc term him an esquire, he ipso facto becomes such, and his eldest son is qualified to kill game etc.'

${ }^{148}$ An exception could be made in respect of any judge appointed to the Supreme Court or to the Senior Courts, as defined in the Senior Courts Act 1981.

${ }^{149}$ ss 3 \& 4 are otiose and need not be repeated in a Crown Act (i.e. ss 1 can refer to 'her' as well as to ' $h i m$. Further, this Act was before the House of Lords (Expulsion and Suspension) Act 2015).

${ }^{150}$ The word comes from the Anglo-Norman 'maire' and, in London, the mayor likely replaced the Anglo-Saxon portreeve (or portgrave) who was the chief civil magistrate elected by the sovereign. The first mayor of London is said to have been Henry Fitz-ailwin appointed by the sovereign in 1189 (or 1192). See McBain, n 125, p 19.

${ }^{151}$ See e.g. Whitaker's Almanack (1960) "Right Honourable" - By long established custom, or courtesy, members of her majesty's most honourable privy council are entitled to be designated 'The Right Honourable', but, in practice, this prefix is sometimes absorbed in other designations; for example, a prince of the blood admitted a privy councillor remains 'His royal Highness'; a Duke remains 'His Grace'; a Marquess is still styled 'Most Honourable'. The style of all other peers, whether privy councillors or not, is 'Right Honourable', although it is more usual to describe them with the prefix 'The' omitting the more elaborate styles. A privy councillor who is not a peer should be addressed as The Right (or Rt) Hon - . A peer below the rank of marquess who is a privy councillor should be addressed as The Right (or Rt) Hon. The Lord (or Earl or Viscount) - PC, or, less elaborately, The Lord (or Earl or Viscount) - PC.'

${ }^{152}$ Cowell, A Law Dictionary or the Interpreter (last ed, 1727)(esquire).
} 
- Honours (Prevention of Abuses) Act $1925^{153}$

- $\quad$ Life Peerages Act 1958 (see above)

- $\quad$ Peerage Act 1963 (see above),

should be placed in a Crown Act.

In conclusion, the Crown prerogative to create the titles of lord mayor (and any deputy) should become statutory. The courtesy titles of 'esquire' and 'right honourable' - as well as the Crown prerogative to create new hereditary (and, possibly, life) peerages - should be abolished.

\section{(m) Legal Prerogatives - Courts \& Commissions}

The Crown has asserted prerogatives in respect of the following, a prerogative to create a:

- common law court; ${ }^{154}$ or a

- $\quad$ commission exercising a judicial function. ${ }^{155}$

From early times, the Crown has had the prerogative to create courts administering the common law - but not one administering equity. However, since the merger of common law and equity in Victorian times, it is hardly likely that the Crown would seek to set up a common law court only, today. Also, attempts by the Crown to create a new court in the past have, often, provoked widespread dis-satisfaction.

- For example, the Court of Star Chamber (abolished in 1641). The same applied to a means of circumventing this restriction by the Crown (under the great seal) setting up a commission. For example, the Court of Commissioners for Ecclesaistical Causes (often, called the 'Ecclesiastical Commission') established in 1686. ${ }^{156}$ Although termed a 'commission' it acted in a judicial capacity. Hence, regardless of the elusive terminology, it was a court - one not acting according to the common law. ${ }^{157}$

Today, it would seem manifest that any court - or commission of a judicial nature - should only be created pursuant to legislation.

In conclusion, the Crown prerogatives to create a common law court - or a commission exercising a judicial function (which is the same thing) - should be abolished as unnecessary and inappropriate.

\section{(n) Legal Prerogatives - Construction of Crown Grants}

The Crown has asserted various prerogatives in respect of Crown grants. That is, to:

- have a Crown grant construed in favour of the Crown; ${ }^{158}$

- $\quad$ have a lost Crown grant presumed; ${ }^{159}$

\footnotetext{
${ }^{153}$ Section 1 states (punishment of abuses in connection with the grant of honours). (1) If any person accepts or obtains or agrees to accept or attempts to obtain from any person, for himself or for any other person, or for any purpose, any gift, money or valuable consideration as an inducement or reward for procuring or assisting or endeavouring to procure the grant of a dignity or title of honour to any person, or otherwise in connection with such a grant, he shall be guilty of a misdemeanour.(2) If any person gives, or agrees or proposes to give, or offers to any person any gift, money or valuable consideration as an inducement or reward for procuring or assisting or endeavouring to procure the grant of a dignity or title of honour to any person, or otherwise in connection with such a grant, he shall be guilty of a misdemeanour. (3) Any person guilty of a misdemeanour under this Act shall be liable on conviction on indictment to imprisonment for a term not exceeding [2] years or to a fine not exceeding [£500], or to both such imprisonment and such fine, or on summary conviction to imprisonment for a term not exceeding [3] months or to a fine not exceeding [£50], or to both such imprisonment and such fine, and where the person convicted (whether on indictment or summarily) received any such gift, money, or consideration as aforesaid which is capable of forfeiture, he shall in addition to any other punishment be liable to forfeit the same to [HM].' This wording should be modernised.

${ }^{154}$ See generally, M1, pp 7-9. Chitty (writing in 1820), n 13, p 75 'The prerogative of creating courts... has been immemorially exercised by the kings of England, and is founded on the capacities of executive magistrate, and distributor of justice, which the constitution of the country has assigned to the sovereign.' However, Chitty (writing in 1820), n 13, p 76, noted that the Crown: (a) cannot grant any addition of jurisdiction to a common law court; (b) cannot authorise anyone to hold a common law court in a manner dissimilar to the law of the land; (c) cannot grant a commission to determine any matter of equity; (d) cannot authorise any court to proceed contrary to English law.

${ }^{155}$ Cf. Chitty (writing in 1820), n 13, p 77 (special commissions).

${ }^{156}$ See Bills of Rights 1688. One of the complaints of Parliament against James II (1685-8) was 'By issuing and causing to be executed a commission under the great seal for erecting a court called the Court of Commissioners for Ecclesiastical Causes'. (spelling modernised). This wording is still extant. The Bill of Rights further declared 'That the commission for erecting the late court of commissioner and ecclesiastical causes and all other commissions and courts of like nature are illegal and pernicious.' (spelling modernised).

${ }^{157}$ This commission was similar to Court of High Commission, which was dissolved in 1641.

${ }^{158}$ Halsbury (4th ed), n 17, vol 8(2), para 860 'Contrary to the ordinary rule applicable to grants by a subject, grants by the Crown are usually construed most favourably for the Crown.' See generally, M8, pp 3-13. Also, Chitty (writing in 1820), n 13, pp 391-99.

${ }^{159}$ See generally, M10, pp 448-57.
} 
- be presumed to be deceived (or mistaken) in a Crown grant; ${ }^{160}$

- be presumed, in a Crown grant, to reserve an advowson - unless the grant expressly provides otherwise; ${ }^{161}$

- re-enter, on a default under a Crown lease, without having to make any demand (i.e. to give any notice). ${ }^{162}$

In respect of these:

- $\quad$ Grants construed in Favour of the Crown. The rationale for such a rule of interpretation was that the sovereign must always be presumed to act for the overall public good. However, this is no more than a legal fiction. Further, there were many exceptions to this rule. Today, it is also inappropriate since the royal demesne no longer exists (now being part of the Crown Estate) and the sovereign is no longer involved, in person, in such grants, which are drafted by professional lawyers. Also, today, the modern rules of interpretation are based on the intention of the parties, generally eschewing legal fictions and artificial rules of construction. If this rule is abolished it will have a negligible effect since it was so little relied on in practice down the centuries and the caselaw is old;

- Presuming a Lost Crown Grant. Given that many Crown grants (especially, those of a byegone age) may have been lost, the courts have been prepared to presume that the Crown had made a grant in certain instances where there are disputes between subjects - even though no document can be produced. ${ }^{163}$ However, today, the courts, generally, eschew presumptions of law (and legal fictions). Instead, they look at the evidence submitted by the parties to see whether a factual conclusion can be arrived at. Further, unlike a presumption, modern judicial interpretation is not weighted - from the outset - in favour of any party such as the Crown. Thus, today, it would seem more appropriate to abolish any such presumption of a Crown grant and, instead, let the courts rely on the evidence submitted in order to reach a conclusion on the facts whether a Crown grant had once been made (one now lost). In any case, if such a presumption of a lost Cown grant is abolished, this will have negligible effect since such a presumption has been little relied on in practice down the centuries (also, so much land in England and Wales is now registered land. And, few 'lost' Crown grants are now asserted - not least since there is little value in them);

- $\quad$ Presumption of Deceit (or Mistake) in a Crown Grant. Many sovereigns were impecunious and they made grants of Crown land without considering the financial consequences (this changed after 1760 since the royal demesne became part of the Crown Estate and the sovereign received funding from a Civil List instead). ${ }^{164}$

- Deception. Given the profligacy of sovereigns, in an effort to redress (i.e. clawback) the situation the courts, sometimes, presumed that the Crown was deceived in its grant (which was then held void) viz: (a) where the Crown granted a greater (or different) estate than it was entitled to; or (b) where the estate (or part of it) had already been granted to another and the prior grant was not recited; or (c) where the Crown had been deceived in the consideration (value) expressed in the grant (i.e. the sum to be paid);

- Mistake. The courts presumed that the Crown was mistaken in a grant where: (a) the Crown was prejudiced by a mistake in a material point (either in its tenure or profit); or (b) where a recital for the Crown's benefit turned out to be false. ${ }^{165}$

Today, generally, at law a party can allege mistake, misrepresentation (both fraudulent and innocent) and deceit. Thus, if these presumptions were abolished the Crown would be no worse off. Indeed, the latter are wider in scope and they are not based on presumption as such but on the factual position being proved. Also, there is no good reason to distinguish, in such matters, Crown from non-Crown grants. Finally, if such presumptions were abolished the practical effect would be negligible, since such presumptions are little relied on today;

- Reserving an Advowson. There was a common law presumption as to the reservation of an advowson in a Crown grant, unless expressly provided otherwise. This became statutory - in the Act of Prerogativa Regis (c.

\footnotetext{
${ }^{160}$ See generally, M8, pp 13-6.

${ }^{161}$ This is also dealt with in the Act, Prerogativa Regis (c. 1272-3), which a Crown Act seeks to abolish.

162 See generally, M9, pp 309-10.

${ }^{163}$ This presumption in law is not the same as the legal rule of prescription. It is based on there being no written document but that the plaintiff had exercised a right prior to 6 July 1189 (i.e. time immemorial).

${ }^{164}$ See generally M1, pp 557-9.

${ }^{165}$ Ibid, M8, pp 13-6.
} 
1272-3) which is still extant. ${ }^{166}$ However, this statutory presumption - which would only apply where a church was on the land - would, likely, not apply to the Crown Estate (the Act being prior to the same). Also, given more methods of drafting which looks at the intent of the parties, such a presumption is not appropriate anyway. The Act has been abolished in Northern Ireland and it has had little caselaw throughout its long history. This Act should be repealed (also, in relation to royal fish);

- $\quad$ Re-entry on Default without Demand. Where a Crown lease contains a provision for re-entry by the Crown on the non-payment of rent, no demand for payment is required (the word 'demand' refers to some form of notice of re-entry being given). However, this rule of law is subject to limitations - such as the grant making provision for a demand. Or, the Crown Lands Act 1623 (still extant) applying. The rationale for such a rule of law was the pre-eminence of the sovereign, when the royal demesne was part of his personal estate. However, since 1760, the royal demesne has been part of the Crown Estate (which employs professional draftsmen and lawyers) and, thus, there is no need for this rule of law. Also, there is no need for such a rule in the case of the Queen's personal property - the likelihood of her leasing her real property may be dismissed as remote. ${ }^{167}$

In Investors Compensation Scheme Ltd v West Bromwich Building Society (1998), the House of Lords rejected the old 'intellectual baggage' in interpreting deeds in favour of 'common sense principles by which any serious utterance would be interpreted in ordinary life ${ }^{\prime}{ }^{168}$ Almost all the above would have concerned deeds since these were the primary form for legal documents from 1290. Thus, the same comment can apply to the above. Discarding such presumptions and rules of law will enable the courts to reach a decision on the facts without any bias towards the Crown.

In conclusion, Crown prerogatives in respect of Crown grants should be abolished.

\section{(o) Legal Prerogatives}

There are various other Crown prerogatives of a legal nature which may be referred to. These include the prerogative of the Crown to:

- $\quad$ exercise certain prerogatives with regard to distress (at common law); ${ }^{169}$

- not have to give a receipt (an acquittance) acknowledging the payment (or the discharge) of any debt to the Crown; ${ }^{170}$

- $\quad$ not be bound by an estoppel: ${ }^{171}$

- $\quad$ not be bound by any legal fictions; $;^{172}$

- $\quad$ compel a person to accept a public office. ${ }^{173}$

As to these:

- Distress at Common Law. Common law distress has been abolished and distress is now regulated by legislation. Thus, any Crown prerogatives relating to the same are spent;

- $\quad$ Not having to give an Acquittance. Where a debt to the Crown was paid (i.e. discharged) by a person, it was said (on the basis of a case in 1487) that the Crown was not bound (compelled) to give an acquittance. i.e. a receipt acknowledging the payment (discharge) of that debt, one given to the debtor. Instead, the same was

\footnotetext{
${ }^{166} \mathrm{Ibid}$, M2, pp 551-2. It provided that 'When our lord the king giveth or granteth land or a manor with the appurtenances, without he make express menion in his deed or writing of...advowsons of churches...belonging to such manor or land, then at this day this the king reserveth to himself such...advowsons...albeit that among other persons it hath been observed otherwise.' See also Chitty (writing in 1820), n 13, pp 392-3.

${ }^{167}$ For example, it is unlikely the sovereign might rent out Balmoral or Sandringham and, in such a case, there is no good reason why the general law should not apply.

${ }^{168}$ Investors Compensation Scheme Ltd v West Bromwich Building Society [1998] 1 AE 98, especially at p 114 per Lord Hoffman.

${ }^{169}$ Chitty (writing in 1820), n 13, pp 208-9. See also Ibid, p 376 (distress could not be made on lands in the king's possession).

${ }^{170} \mathrm{Ibid}, \mathrm{p} 378$ 'on account of the dignity of the king, he is not bound to offer an acquittance to any man; but the subject who pays to the king ought to bring with him an acquittance, and demand it of the king.'

${ }^{171}$ Ibid, p 381 'The king is not bound by...estoppels, even though such estoppels would affect the party through whom the Crown claims. But this does not prevent the king from taking advantage of estoppels, though they ought in general to be mutual.' See also M10, pp 462-6.

${ }^{172}$ See generally, M10, pp 460-2. Also, Chitty, n 13, p 381 'The king is not bound by fictions or relations of law...'.

${ }^{173}$ Ibid, M1, pp 17-9. Chitty (writing in 1820), n 13, pp 18-9 'His Majesty may also, on any occasion, employ, and compel his subjects to serve in such offices or functions as the public good and the nature of the constitution require. It is a general rule, that where a person is legally called upon to perform a public duty, he is liable to be punished of he refuse to perform it. Hence, for instance, a lawyer is bound on pain of punishment to accept the degree of sarjeant at law [now obsolete], when called thereto by the king's writ; nor can a person duly appointed sheriff legally refuse to execute that office. This doctrine is not confined to cases of offices immediately under the Crown, nor to officers appointed by his majesty; for persons named jurymen or parish officers must serve.'
} 
required to solicit it (i.e. provide evidence of payment and request a confirmation of the same). ${ }^{174}$ This was based on the pre-eminence of the sovereign. Today, the Crown (as opposed to the sovereign) does provide evidence of payment as a matter of course (i.e. when a person pays their taxes). And, in the case of the sovereign, it is unlikely that persons would incur debts to her personally. However, if so, there is no good reason that some evidence be provided by the Crown that such has been paid off. Thus, this rule of law may be dispensed with as obsolete;

- Not bound by an Estoppel. It is likely this rule of law was restricted to estoppels when the document was in the form of a deed and not in other writings. Halsbury suggests this is the modern interpretation ${ }^{175}$ - albeit an old case (Coke's Case (1623) is more expansive. As it is, this rule of law is subject to considerable limitations (the Crown does seem to be bound by equitable estoppels and those in pais - which would apply in the case of a legal document not in the form of a deed). Further, such a rule is little more than an aspect of the Crown being able to plead that it was deceived (mis-led) in its grant (see (n) above). Given the paucity of cases and the questionable nature of this rule, it should be dispensed with as obsolete;

- Not bound by Legal Fictions. The statement that the Crown is not bound by fictions of law is a bald one and the meaning of the concept of a legal fiction is different to what it was when reference was made to the same in the case of Lord Sheffield $v$ Ratcliffe $(1615)^{176}$ which is generally cited as the source of such a proposition. In that case the dictum of the court may have been mis-reported. ${ }^{177}$ In any case, the court may have intended to limit it to legal fictions seeking to avoid the law on mortmain (now abolished). Further, it seems clear that the Crown is bound by fictions such as the sovereign not being able to be a minor in law or that the Crown can do no wrong. In conclusion, such a prerogative is dubious, (very) rarely relied on and unnecessary in modern times. It should be abolished;

- Compel to Accept a Public Office. In early times, public offices - such as serving as an alderman or a parish constable - incurred time and expense (or loss of money) and were not at all popular. Thus, the Crown could force a subject to undertake a public office - albeit fines were often paid instead (or exemptions granted). ${ }^{178}$ Further, it was (and still is, technically) a common law criminal offence for a duly qualified person to refuse to serve in a public office to which he has been appointed and in which he is required by law to serve. ${ }^{179}$ The offence is punishable by life imprisonment (!) or for a shorter term and by a fine at the discretion of the court. However, the caselaw is old (pre-1832, it seems) and legislation provides that a court cannot generally compel a person to work. ${ }^{180}$ Further, the need for compulsion is no longer necessary in the case of a public office since such are now paid and there is rarely an absence of applicants. Thus, such a prerogative - and any criminal offence - is no longer needed. Both should be abolished.

In conclusion, these legal prerogatives should be abolished.

\section{(p) Personal Prerogatives}

There are various other Crown prerogatives which relate to the sovereign in a personal capacity which may be referred to. These comprise the prerogative of the sovereign, in person, to:

- $\quad$ sit as a judge; ${ }^{181}$

- withdraw a case from a court (that is, order a court to refuse to hear it); ${ }^{182}$

- $\quad$ order a court to delay giving judgment; ${ }^{183}$

- $\quad$ sue in whatever court the sovereign pleases; ${ }^{184}$

\footnotetext{
${ }^{174}$ i.e. the onus was on the debtor to evidence that he had re-paid the debt.

${ }^{175}$ Halsbury, (4th ed), n 17, para 385 'The Crown...may possibly take advantage of estoppel by deed, though not, it seems, where the estoppel arises through its own letters patent.' See also Chitty, n 171 above.

${ }^{176}$ Lord Sheffield $v$ Ratcliffe (1615) Jenks 286 at 287 'The king is not bound by abeyance; nor by a common recovery where he has a reversion expectant upon an estate tail; nor by a collateral warranty of his ancestor, without assets: he is not bound by fictions of law.'

${ }^{177}$ The words may have been mis-reported and the court may actually have said 'he is not bound by these fictions of law.'

${ }^{178}$ Chitty, n 13, p 20.

${ }^{179}$ See GSMcBain, Abolishing some Obsolete Common Law Crimes (2009) 20 King's Law Journal, pp 113-4.

${ }^{180}$ Ibid. See also Trade Union and Labour Relations (Consolidation) Act 1992, s 236. Also, Halsbury (4th ed), n 17, vol 8(2), para 27.

${ }^{181}$ See generally, M1, pp 9-11. Chitty (writing in 1820), n 13, p 377 'the king cannot personally execute any office, judicial or ministerial.' Ibid, p 75 'the king cannot determine any cause or judicial proceeding, but by the mouth of his judges...'

${ }^{182}$ Ibid, p 10.

${ }^{183}$ Ibid, pp 10-1.

${ }^{184}$ Ibid, p 11. Chitty (in 1820), n 13, p 244 'the king has the undoubted privilege of suing in any court he pleases' (however all the instances given are in respect of courts no longer in existence).
} 
- $\quad$ use special forms of court procedure; ${ }^{185}$

- $\quad$ not pay (or receive) legal costs; ${ }^{186}$

- $\quad$ have their personal property exempt in the case of: (i) wreck (at common law); (ii) estrays; (iii) waifs; (iv) customary rates and tolls, ${ }^{187}(\mathrm{v})$ distress for rent; ${ }^{188}$

- be exempt from the enforcement of any lien, pledge or debt in execution against the sovereign; ${ }^{189}$

- $\quad$ approve the marriage of a queen dowager; ${ }^{190}$

- $\quad$ exempt a person from any liability imposed by legislation or the common law; ${ }^{191}$

- $\quad$ pardon (or reprieve) a person; ${ }^{192}$

- $\quad$ act as visitor in the case of a chartered corporation. ${ }^{193}$

As to these:

(a) Sitting as a Judge. From Anglo-Saxon times, the sovereign controlled the administration of justice by establishing courts and appointing judges. Whether he ever sat in person to deliver judgment qua judge is dubious. More likely, the sovereign delivered the judgment of his judges in especially important cases - in order to emphasis the finality of its verdict and his support for it. Or, he sat as a visitor - to accord greater solemnity to the proceedings. The same may have applied in Norman times. ${ }^{194}$ As it is, the case Prohibitions del Roy (1607) confirmed that the sovereign could not sit as a judge in the royal courts. Today, it is most unlikely that a sovereign would seek to do so. However, any Crown prerogative to do so should be abolished, in order to clarify the matter;

(b) Order to Withdraw a Court Case. The sovereign cannot order a case to be withdrawn from submission to a court. This was established in Brownlow $v$ Cox and Michil (1615). Also, in the case, Prohibitions del Roy (1607) which held that the "king cannot take any cause out of any of his courts, and give judgment upon it himself. ${ }^{195}$ Today, it is most unlikely that a sovereign would seek to do the same. However, any Crown prerogative to do so should be abolished, in order to clarify the matter;

(c) Order a Court to Delay Judgment. In the case of Commendans (1616), James I (1603-25), pursuant to an asserted Crown prerogative, directed the Attorney-General (Francis Bacon) to write to Coke CJ requesting (or, rather, commanding) that the judges delay their decision until the king had spoken with them. A joint letter was sent by the judges in reply - indicating their oath forbade them to delay justice. However, after attending an audience with the sovereign, the majority reversed their opinion, with the exception of Coke CJ (which must go to his great credit). ${ }^{196}$

\footnotetext{
${ }^{185}$ Ibid, pp 11-2.

${ }^{186} \mathrm{Ibid}, \mathrm{p} 12$.

${ }^{187}$ A Crown Act seeks to abolish (i)-(iv), anyway.
}

${ }^{188}$ See M9, pp 292-304. Chitty, n 13, pp 376-7 'The king is not liable to pay taxes, toll, pontage, passage, custom or poor rates; nor is his personal property subject to the laws relative to wreck, estrays, waifs, sale in market overt, distress damage feasant, or the like.' (italics supplied). Ibid, p 376 'Nor can a distress be made on lands in the king's possession.' Pontage and passage are forms of toll. Sale in market overt, distress damage feasant and poor rates have been abolished. The taxes and tolls referred to here are common law ones (in the case of statutory taxes, whether the sovereign is exempt depends on the interpretation of the legislation).

${ }^{189}$ See M1, pp 15-6. Chitty (writing in 1820), n 13, p 376 'The king's goods are...exempt from various liabilities, which affect the personalty of his subjects. Even if a subject succeed in a petition against the king, his majesty's goods are not liable to be taken in execution.'

${ }^{190}$ See M3, p 115, n 107.

${ }^{191}$ Chitty (writing in 1820), n 13 mentioned cases of exemption from : (a) an obligation to service in a public office (p 20); (b) impressment in the navy (p 48); (c) matters relating to trade and taxes (by way of dispensation), p 95; (d) a criminal punishment, by granting a pardon (or reprieve), pp 88-103.

${ }^{192}$ Ibid, p 88 'the right to pardon [is] vested...in the sovereign.' Also, Halsbury, (n 17), (1st ed), vol 6, pp 404-7.

${ }^{193} \mathrm{Ibid}, \mathrm{pp} 130-1$ 'The founder of all corporations in the strictest and original sense is the king alone..'. Ibid, pp 130-1 'A visitor is a person appointed by law to inspect the proceedings of corporations, and to secure their adherence to the purposes of their institution, and to settle in general, without appeal from his decision, any disputes respecting their management....The king being thus constituted by the law, visitor of all civil corporations, the law has also appointed the place wherein he shall exercise his jurisdiction, which is the court of king's bench; where, and where only, all misbehavious of this kind are inquired into and redressed and all controveries decided.'

${ }^{194}$ Cf. Prohibitions del Roy (1607) 12 Co Rep 63 (77 ER 1342), p 64 'the judges informed the king, that no king after the Conquest [i.e. after 1066] assumed to himself to give any judgment in any cause whatsoever, which concerned the administration of justice within his realm, but these were solely determined in the courts of justice.'

${ }^{195}$ Ibid. These cases ended the power of the writ De non Procedendo Rege Inconsulto.

${ }^{196}$ Coke would seem to have been (clearly) right in that the Statute of Northampton (1328) c 9 provided: 'it is accorded and established, that it shall not be commanded by the great seal nor the little seal to disturb or delay common right; and though such commandments do come, the justices shall not therefore leave [i.e. fail] to do right in any point.' 
Today, it is most unlikely a sovereign would seek to do the same. However, any Crown prerogative to do so should be abolished, to clarify the matter;

(d) Sue in whatever Court the Sovereign Pleases. It is said that the sovereign retains the prerogative to sue in whatever court she pleases. This was based on a section (chapter) of Magna Carta (chapter 11) which indicated that the sovereign could sue in the king's bench for his debt (albeit, the usual court would have been that of the common pleas). ${ }^{197}$ However, this chapter of Magna Carta has been repealed. Further, such a rule of law is obsolete since the whole structure of the High Court is different to that in medieval times (also, there are now courts of appeal - the Court of Appeal and the Supreme Court - which did not previously exist). There is no good reason for the sovereign having such a privilege today. Thus, such a rule of law should be abolished;

(e) Special Court Procedure. The sovereign in person may still use certain special forms of procedure not available to others, including the Crown in general. Halsbury refers to proceeding by way of: (a) information; (b) inquisitions or inquests of office; (c) extents; (d) scire facias; (e) quo warranto; (f) mandamus. ${ }^{198}$ However, the sovereign can waive these. ${ }^{199}$ There is no good reason to retain this prerogative and it is unlikely to be invoked in modern times, where the sovereign only exercises a formal role (and her personal role is, now, almost negligible). Thus, this prerogative should be abolished, as unnecessary;

(f) Not Pav or Receive Legal Costs. A prerogative that the sovereign (or any person acting for her) does not pay (or receive) costs relates, today, only to her acting legally in a personal capacity. There would seem to be no good reason to retain such a rule (not least, since - in civil proceedings - costs are at the discretion of the court). ${ }^{200}$ Thus, this prerogative should be abolished;

(g) Exemption re Personal Property at Common Law. By reason of the eminence of their office, the sovereign had the prerogative that his/her personal property was exempt in certain situations relating to the common law (it was not intended to cover legislation which depends on the interpretation of the same). Thus, the personal property of the sovereign could not be treated as part of wreck (when wrecked). Nor could their animals be treated as estrays (strays). Nor their property, if stolen, be treated as a waif. Nor, were they subject to customary rates and tolls - that is, tolls and rates arising under the common law. Nor could their animals be treated as subject to distress for rent (at common law).

- $\quad$ Estrays and waifs are obsolete legal concepts now (see 27).

- Distress for rent at common law has been abolished (the position is now statutory).

- $\quad$ The prospect of the sovereign's personal property being subject to wreck (and, if such, unclaimed) is remote. In any case, the law is now statutory. Under the Merchant Shipping Act 1995, s 241, the Crown is entitled to unclaimed wreck. Thus, it would pass back to the sovereign in any case if not otherwise claimed by her;

- $\quad$ There are very few (if any) Crown customary rates and tolls still existing today (the exemption does not include statutory tolls) and most have become contractual to the extent they still exist.

Thus, all of these exemptions may be abolished as theoretical or no longer of relevance. Chitty (in 1820) also argued that the sovereign was exempt from tithes on demesne land. ${ }^{201}$ However, demense land is now part of the Crown Estate. And, tithes have been abolished in most instances as well as being statutory. Thus, this prerogative should also be abolished;

(h) Exemption re Pledge, Lien, Execution for Debt. There is an early case (in 1465) indicating that the sovereign is exempt from the enforcement of a pledge. ${ }^{202}$ Thus, the same would, likely, apply to any lien (for example, one incurred on a person repairing her personal property, who remains unpaid). Also, for unpaid debts. However, today, it is asserted that any such exemption (immnuity) should be removed and it is unlikely that, in practice, there will be any problem;

\footnotetext{
${ }^{197}$ Halsbury (4th ed), n 17, vol 8(2), para 391 'The Crown might in general choose its own forum and sue in what court it pleased, and in this respect the monarch in her prívate capacity has the former attributes of the Crown.'

${ }^{198}$ For the background to these, see Chitty (writing in 1820), n 13, pp 245-339.

${ }^{199}$ Halsbury (4th ed), vol 8(2), n 17, para 391.

${ }^{200}$ It may also be noted that other members of the royal family - such as the Duke of Cornwall - do not have such a prerogative.

${ }^{201} \mathrm{Ibid}, \mathrm{p} 377$ 'his majesty being persona mixta, is capable of a discharge de non decimando, by prescription, which in effect operates as a general discharge from tithes.'

${ }^{202}$ See M1, pp 15-6, including p 16, n 107.
} 
(i) Marriage of a Dowager Queen. At common law the consent of the sovereign appears to have been required in the case of the marriage of a dowager queen ${ }^{203}$ and it is unclear whether the Succession the Crown Act 2013 has superceded this (it applies to those in line to the throne only, it seems). It is asserted that such a prerogative (even if it still exists) is not required and should be abolished;

(j) Exemption from Legislative or Common Law Liability. The Crown had a (limited) Crown prerogative to exempt a person from various legislative or common law liabilities. For example, it could grant an exemption from:

- an obligation to serve in a public office (a common law obligation);

$\circ$ impressment in the navy (and, possibly, the army);

- matters relating to trade and taxes, by way of dispensation;

○ a criminal punishment, by granting a pardon, a conditional pardon or a reprieve (see below).

More notoriously, the sovereign asserted the prerogative to grant, in effect, permission for a person to breach laws with impunity. That is, a suspension or dispensation from the law. ${ }^{204}$ This asserted prerogative was much mis-used and bitterly resented. Thus, the Bill of Rights 1688 (extant) provides that:

'no dispensation by non obstante, of or to any statute [i.e. legislation], or any part thereof, shall be allowed, but that the same shall be held void and of no effect, except a dispensation be allowed of in such statutes. ${ }^{205}$

As Chitty noted, this provision covered the statutory position in respect of dispensations. However, this did not affect dispensations re common law offences that were mala in $s^{.206}$ To put the matter beyond doubt it would seem appropriate to abolish the right of the Crown to exempt from legislative or common law liability. Also, to re-state, in a Crown Act, the position in the Bill of Rights 1688 as to dispensations and suspensions; ${ }^{207}$

(k) Pardon (or Reprieve) a Person. The sovereign had the prerogative to pardon and remit the consequences of a violation of the law, where the prosecution was carried out in the name of the sovereign. ${ }^{208}$ Today, it would seem appropriate that any pardon by granted pursuant to legislation, as opposed to any Crown prerogative. And, that the same be exercised by the Crown (i.e. the sovereign in the body politic) as opposed to the sovereign in person. Thus, any personal power to pardon (or reprieve) ${ }^{209}$ should be abolished;

(l) Visitor to Chartered Corporations. A visitor is a person appointed by law to inspect the proceedings of corporations, and to secure their adherence to the purposes of their institution. Also, to settle in general, without appeal from his decision, any disputes relating to their management. However, the sovereign - although, by law, visitor of all civil corporations - appointed the King's Bench to exercise this jurisdiction, long ago. ${ }^{210}$ Thus, any Crown prerogative for the sovereign to act in person should be abolished.

In conclusion, these personal prerogatives of the sovereign should be abolished, as no longer required.

\section{(q) Perogatives in Connection with the Bill of Rights 1688}

The Bill of Rights 1688 refers to various abuses of law committed by James II (1685-8) ${ }^{211}$ who later fled the realm and was held by Parliament to have abdicated. Such abuses Parliament - in the Bill of Rights 1688 - declared to be illegal and void ( $I$ have inserted numbering and modernised the spelling), stating:

\footnotetext{
${ }^{203}$ See M3, p 115, n 107.

${ }^{204}$ Chitty (writing in 1820), n 13, p 95 'the ancient supposed right of the king to grant suspensions, or dispensations of the laws, non obstante aliquo statuto in contrarium, before the commission of an offence; or in other words, suffering a person to commit a breach of the laws with impunity, by rendering him dispunishable. This was a prerogative which almost all our antient kings exercised; it was replete with absurdity, and might be converted to the most dangerous purposes.'

${ }^{205}$ In the case of suspension, the Bill of Rights 1688 declared 'that the pretended power of suspending of laws or the execution of laws by regal authority without consent of Parliament is illegal.'

${ }^{206}$ For mala in se and mala prohibita, see Chitty (writing in 1820), n 13, pp 95-6.

${ }^{207}$ For the latter, see $\mathrm{n} 205$.

${ }^{208}$ Chitty (writing in 1820), n 13, p 90 'The king's right to pardon and remit the consequences of a violation of the law, is confined to cases in which the prosecution is carried on in his majesty's name for the commission of some offence affecting the public, and which demands public satisfaction, or for the recovery of a fine or forfeiture, to which his majesty is entitled.'

${ }^{209} \mathrm{Ibid}, \mathrm{p} 97$ 'The term reprieve is derived from reprendre, to keep back, and signifies the withdrawing of the sentence for an interval of time, and operates in delay of execution.'

${ }^{210}$ Ibid, pp 130-1.

211 'Whereas the late King James the Second by the Assistance of diverse evill Councellors Judges and Ministers imployed by him did endeavour to subvert and extirpate the Protestant Religion and the Lawes and Liberties of this Kingdome. 1. Dispensing and Suspending Power. By Assumeing and Exerciseing a Power of Dispensing with and Suspending of Lawes and the Execution of Lawes without Consent of Parlyament. 2. Committing Prelates. By Committing and Prosecuting diverse Worthy Prelates for humbly Petitioning to be excused from
} 
1. Dispensing Power. That the pretended power of suspending of laws or the execution of laws by regal authority without consent of Parliament is illegal. (italics supplied)

2. Late dispensing Power. That the pretended power of dispensing with laws or the execution [i.e. the operation] of laws by regal authority as it has been assumed and exercised of late is illegal. (italics supplied)

3. Ecclesiastical Courts illegal. That the commission for erecting the late Court of Commissioners for Ecclesiastical Causes and all other commissions and courts of like nature are illegal and pernicious.

4. Levying Money. That levying money for or to the use of the Crown by pretence of prerogative without grant of Parliament for longer time or in other manner than the same is or shall be granted is illegal.

5. Right to Petition. That it is the right of the subjects to petition the king and all commitments and prosecutions for such petitioning are illegal.

6. Standing Army. That the raising or keeping a standing army within the kingdom in time of peace unless it be with consent of Parliament is against law.

7. Subjects' Arms. That the subjects which are protestants may have arms for their defence suitable to their conditions and as allowed by law.

8. Freedom of Election. That election of members of Parliament ought to be free.

9. Freedom of Speech. That the freedom of speech and debates or proceedings in Parliament ought not to be impeached or questioned in any court or place out of Parliament.

10. Excessive Bail. That excessive bail ought not to be required nor excessive fines imposed nor cruel and unusual punishments inflicted.

11. Juries. That jurors ought to be duly impannelled and returned.

12. Grants of Forfeitures. That all grants and promises of fines and forfeitures of particular persons before conviction are illegal and void.

13. Frequent Parliaments. And that for redress of all grievances and for the amending strengthening and preserving of the laws Parliaments ought to be held frequently.

In respect of these, nos $1 \& 2$ have been considered in (p) above. No 3 has, also, been previously considered (see (m) above). Nos 8, 9 and 13 would be better placed in a Parliament Act. Nos 6 and 7 are obsolete (the matters now being provided for in legislation). ${ }^{212}$ As for the remainder, a Crown Act should abolish the following above asserted Crown prerogatives, any prerogative to:

- $\quad$ restrict a subject's right to petition the Crown (see no 5);

- $\quad$ interfere in the grant of bail by a court (see no 10 );

- $\quad$ interfere in the fining of a person by a court (including the amount of the fine) (see no 10);

- $\quad$ interfere in the punishment awarded by a court (see no 10);

- $\quad$ interfere in the selection (or empanelling) of a jury (see no 11);

- franchise any court fine (see no 12).

Concurring to the said Assumed Power.3. Ecclesiastical Commission. By issueing and causeing to be executed a Commission under the Great Seale for Erecting a Court called The Court of Commissioners for Ecclesiasticall Causes. 4. Levying Money. By Levying Money for and to the Use of the Crowne by pretence of Prerogative for other time and in other manner then the same was granted by Parlyament. $\mathbf{5}$. Standing Army. By raising and keeping a Standing Army within this Kingdome in time of Peace without Consent of Parlyament and Quartering Soldiers contrary to Law. 6. Disarming Protestants, \&c. By causing severall good Subjects being Protestants to be disarmed at the same time when Papists were both Armed and Imployed contrary to Law. 7. Violating Elections. By Violating the Freedome of Election of Members to serve in Parlyament. 8. Illegal Prosecutions. By Prosecutions in the Court of Kings Bench for Matters and Causes cognizable onely in Parlyament and by diverse other Arbitrary and Illegall Courses. 9. Juries. And whereas of late yeares Partiall Corrupt and Unqualifyed Persons have beene returned and served on Juryes in Tryalls and particularly diverse Jurors in Tryalls for High Treason which were not Freeholders, 10. Excessive Bail. And excessive Baile hath beene required of Persons committed in Criminall Cases to elude the Benefitt of the Lawes made for the Liberty of the Subjects. 11. Fines. And excessive Fines have beene imposed. 12.Punishments. And illegall and cruell Punishments inflicted. 13. Grants of Fines, \&c. before Conviction, \&c. And severall Grants and Promises made of Fines and Forfeitures before any Conviction or Judgement against the Persons upon whome the same were to be levyed. All which are utterly directly contrary to the knowne Lawes and Statutes and Freedome of this Realme.'

${ }^{212}$ After the Glorious Revolution 1688, a standing army was permitted with the consent of Parliament. The carrying of weapons is now regulated by general legislation and is not dependent on relgious affiliation. 
The reason for such is to confirm that the Crown (as in 1688) had - and has - no such prerogative in such matters. Also, nos 1 and 2 above confirmed the illegality of any asserted Crown prerogative to suspend or dispense with laws. This, also, should be reflected in a Crown Act, viz.

(1) Any Crown prerogative to suspend, or dispense, with:

(a) legislation (including by way of non obstante); or

(b) the common law; or

(c) the operation of (a) or (b),

is abolished. ${ }^{213}$

In conclusion, a Crown Act should confirm that any asserted Crown prerogative in respect of certain matters is abolished.

\section{(r) Perogatives in connection with the Act of Settlement 1700}

Impeachment was a means of Parliament punishing - by Parliamentary means - powerful persons who might otherwise prevent the courts trying them. The process of impeachment is now, almost certainly, obsolete. ${ }^{214}$ However, the Act of Settlement 1700 (still extant) provides that: ' $n o$ pardon under the Great Seal of England be pleadable to an impeachment by the Commons in Parliament. ${ }^{215}$ The reason for this was that the Crown was asserting that it had a prerogative to pardon a person impeached. This, to enable the same to avoid the penalties imposed by Parliament flowing from the impeachment. Thus, it would seem appropriate for a Crown Act to abolish, out of caution, any such prerogative (at least, until the process of impeachment is, itself, abolished).

In conclusion, any Crown prerogative to pardon an impeachment by the House of Commmons should be abolished.

\section{CROWN PREROGATIVES - OTHER MATTERS}

In section 8, reference was made to the abolition of various Crown prerogatives. Regard to the abolition of a number of consequential matters that flow from this should be given.

\section{(a) Counties Palatine}

The Crown prerogative to create a county palatine should be abolished as unnecessary (see $\mathbf{8}(\mathbf{j})$ ). Further, as indicated in that section, counties palatine still existing (those of Chester, Durham and Lancaster) should also be abolished since they exist only in name. Thus, the following should be abolished, the:

- county palatine of Chester and the title 'Earl of Chester';

- county palatine of Durham, without prejudice to the Durham (County Palatine) Act 1858;

- county palatine of Lancaster;

- office of Attorney-General of the county palatine of Durham;

- office of Solicitor-General of the county palatine of Durham.

A Crown Act should also re-state s 2 of the Durham (County Palatine) Act 1858, s 2 (it vests the foreshore of Holy Isle in the Crown). ${ }^{216}$ Also, $\mathrm{s} 4$ (rents and proceeds from the foreshores of Durham to be divided equally between the Crown and the Ecclesiastical commissioners) which states:

All rents and profits and other monies which may be received by the Crown Estate Commissioners, under the provisions of this Act or otherwise howsoever, from, and the proceeds of any sales or dispositions made by them or either of them of, any part of the bed or shores of any navigable river so far as the tide flows, or of the shores of the sea below high-water mark, or of any inclosures, embankments, and encroachments made therefrom or thereupon respectively within the county of Durham, and after deducting thereout all costs, charges, and expenses in any wise incidental to the sale or management or recovery of such property, shall be divided into moieties; and one moiety of such rent, profits, monies, and proceeds shall be applied by the Crown Estate Commissioners, as part of the hereditary possessions and land revenues of the Crown and the other moiety thereof shall be paid by the same Commissioners to the Church Commissioners; but, notwithstanding this provision for the apportionment of the said rents, profits, monies, and proceeds, the said Church Commissioners shall have no right to interfere with the management or

\footnotetext{
${ }^{213}$ In the case of no 1, reference is made to the contrary consent of Parliament, but not in no 2. In modern times, it would seem better to abolish both, since Parliament, in legislation, may otherwise consent to either (if required).

214 See McBain, n 95.

${ }^{215}$ See also Chitty (writing in 1820), n 13, pp 9 \& 92.

${ }^{216} \mathrm{~s} 2$ (the interest of the bishoprick of Durham in the foreshores of the county of Durham vested in [HM]). 'nothing in this Act contained shall extend to the island called Holy Island, situate in that part of the County Palatine of Durham called Islandshire.'
} 
disposition of such property, which shall be managed and disposed of in all respects as part and parcel of the hereditary possessions of the Crown, and as if no such provision as last aforesaid had been made.

Indeed, consideration should be given to the Crown acquiring the portion of the Church Commissioners, to simplify things.

\section{(b) Tenurial Services to the Crown}

After the Norman Conquest of England in 1066, William I (1066-87) instituted a system of feudal land tenure. That is, the holding of land from him in return for services rendered to him (or to other landed tenants). These services could be military, ecclesiastical or agricultural. In consequence of receiving land form the sovereign (whether directly or indirectly) the tenant was obliged to pay homage (or fealty) to him.

- Homage created an obligation by the tenant to his lord to render assistance to the latter in return for protection;

- Fealty created an obligation by the tenant to his lord to faithfully perform the service he was obliged to perform. ${ }^{217}$

These tenurial obligations of homage and fealty were distinct from allegiance owed to the sovereign - which applied whether or not any homage (or fealty) was paid or any oath of homage (or of fealty or allegiance) was given. The Tenures Abolition Act 1660 (the ' 1660 Act') abolished most of these tenurial obligations. However, it left behind some remnants. These are now obsolete and some should be abolished in a Crown Act viz.

- $\quad$ honorary grand sarjeanty - save in relation any coronation service;

- $\quad$ petty serjeanty;

- $\quad$ any obligation to pay homage (including any oath);

- $\quad$ any obligation to pay fealty (including any oath).

As to these:

- $\quad$ Grand \& Petty Sarjeanty. Grand sarjeanty was a form of military service rendered by a knight (i.e. knight's service) but of a more exalted kind. ${ }^{218}$ It was abolished by the 1660 Act. However, what was not abolished was any honorary grand sarjeanty (which, being honorary, is not legally enforceable). Today, in practice, this service is limited to performing certain functions at the coronation of the sovereign. Thus, it should be abolished - save in relation to the coronation. ${ }^{219}$ Petty sarjeanty was also abolished by the 1660 Act - save for honorary service. However, honorary petty sarjeanty is long obsolete and no longer performed in practice, save on very rare occasions. It should also be abolished;

- $\quad$ Homage \& Fealty. Homage and fealty was abolished, generally, by the 1660 Act. However, statutory exceptions were preserved in the case of the Church of England ('CoE') and the Mayor of London (possibly, because they were overlooked).

- Election of a Bishop. On the election of a diocesan bishop (or archbishop) of the CoE (but not a foreign or suffragan bishop) the Appointment of Bishops Act 1533, s 4 requires them to give oaths of homage and fealty. This is no longer required since these bishops were not rendering tenurial homage as such (i.e. homage in return for land held from the sovereign). Instead, it was to deal with the historical position of the bishop not (formerly) receiving the gift of a ring and a crozier from the Pope but, rather, from the sovereign, when relations between the Catholic church and English sovereigns were very complex. ${ }^{220}$ Today, this homage is purely ceremonial and creates no legally binding tie as such. It can be dispensed with;

- Mavor of the City of London. When appointed, the mayor swears an oath of fealty to the sovereign (actually, in the presence of Queen's bench judges, rather than before the sovereign). This is pursuant to the City of London (Various Powers) Act 1959, s 5.221 However, such fealty is now ceremonial only since the City of London is no longer held by the sovereign in burgage (i.e. the sovereign no longer owns it). ${ }^{222}$

\footnotetext{
${ }^{217}$ See GS McBain, Modernising English Land Law - Part 2, International Law Research (2019), vol 8, no 1, p 90. Also, GS McBain, Modernising the Law on Oaths and Affirmations (2020) International Law Research (2019), vol 8, no 1, pp 6-7, 32-4.

${ }^{218}$ Chitty (writing in 1820), n 13, p 81 'Upon the establishment of the feudal law our kings frequently granted lands to their subjects, reserving some honorary services to be done by the grantees and their heirs, to the king himself: such as to carry his banner, or his sword, or to be his sewer, carver, or butler at his coronation. This was called tenure by grand sarjeanty, and the right of performing these services was considered of great honour, many which still exist and are claimed to be exercised at every coronation.' See also GS McBain, Abolishing Obsolete Offices (2012) Coventry Law Journal, vol 17, no 2, pp 43-51 (grand and petty sarjeanty).

${ }^{219}$ See $\mathrm{n} 217$ (first article), p 96.

${ }^{220}$ Ibid (second article), pp 33-4.

${ }^{221}$ See McBain, n 125, pp 19-20.

${ }^{222}$ Because the sovereign held title to the City, the oath was given by the mayor on behalf of himself and all the other tenants (the other citizens of London). Burgage meant the holding of land from the Crown, when the same was a burg (a fortified town), see n 123.
} 
Also, it is (very) dubious whether the sovereign could (or would) remove a mayor, today - one who is otherwise validly choosen. Thus, the mayor is no longer the Queen's man as such.

Finally, the Tenures Abolition Act 1660, s 4 may also be repealed as spent. ${ }^{223}$

In conclusion, the above matters should be dispensed with, including the statutory requirements in respect of homage and fealty referred to above. Abolition of homage and fealty will not affect any obligation of allegiance (which does not require any oath for its existence, anyway).

\section{CROWN JEWELS, ROYAL PALACES \& ROYAL COLLECTIONS, OSBORNE ESTATE}

A Crown Act should also clarify 'who owns what' in the case of the sovereign, in order to remove uncertainty. That is, it should be clarified that it is the Crown in the body politic (not the body natural) who owns, inter alia, the following, the:

- Crown Jewels

- Royal Palaces

- Royal Collections.

Long ago, it may have been that the Crown jewels were owned by the sovereign in a personal capacity. At least, he sought to treat them as such since they were (quite often) pawned by impecunious sovereigns. For example, Henry VI (1422-61,14701) who pledged them. ${ }^{224}$ However, it is clear, today, that the Crown jewels belong to the nation and not to the sovereign as such. ${ }^{225}$ The same would seem to also, clearly, apply to things such as the Royal Palaces and the Royal Collections which have been maintained by the State for a long time. ${ }^{226}$ The Osborne Estate is also owned by the nation, pursuant to the Osborne Estate Act 1902 and mention should also be made of it in a Crown Act.

In conclusion, a Crown Act should make provision on the ownership of the Crown jewels, Royal Palaces and Royal Collections.

\section{GREAT SEAL \& ROYAL SIGN MANUAL}

The common law on the great seal is antiquated (the privy seal and signet have been abolished). ${ }^{227}$ Thus, it is unclear as to the circumstances in which it may be required pursuant to the common law. Also, legislation on the use of the great seal is antiquated. ${ }^{228}$ Thus, such matters should be set out in a Crown Act, one using modern terminology. So, too in the case of the royal sign manual (signature). ${ }^{229}$

In conclusion, a Crown Act should make provision as to the use of the great seal and the royal sign manual.

\section{PROCLAMATIONS}

The Crown has a prerogative to enact subordinate legislation called a proclamation (a successor to the medieval Crown ordinance). Proclamations are passed under the great seal. The extent of this prerogative is limited since proclamations are only legally binding on the subject when they do not: (a) contradict the law; or (b) seek to make new law. ${ }^{230}$ Historically, the use of proclamations was abused by sovereigns and, today, they are greatly restricted - both in their nature and scope. . $^{231}$ Technically, a person can be fined and imprisoned for breaching a proclamation. However, when such last occurred is uncertain

\footnotetext{
${ }^{223}$ Section 4 states: (all tenures to be created by the king hereafter to be in free and common socage). 'and that all tenures hereafter to be created by the king's majesty his heirs or successors upon any gifts or grants of any manors, lands, tenements or hereditaments of any estate of inheritance at the common law shall be in free and common socage, and shall be adjudged to be in free and common socage only, and not by knight service or in capite, and shall be discharged of all wardship value and forfeiture of marriage, livery, primer-seisin, ouster le main, aid pur faier fitz chivalier \& pur file marrier, any law statute or reservation to the contrary thereof any wise notwithstanding.' (spelling modernised and commas added). The wording in italics is long spent. The rest has been superceded by the Law of Property Act 1925 , $\mathrm{s} 1$, see McBain, $\mathrm{n} 217$ (first article), $\mathrm{p} 86$.

${ }^{224}$ See M1, pp 15-6.

${ }^{225}$ Halsbury (4th ed), n 17, vol 12(1), para 374 'The Crown may not grant away the jewels of the Crown, which are heirlooms and as such do not pass to the executor.' Chitty (writing in 1820), n 13, p 238 'As the antient jewels and treasure of the Crown are necessary to support the splendour and dignity of the sovereign for the time being, they are considered heir-looms, and descend to the successor to the throne, and not to the executor of the last monarch, and, consequently, they are not devisable. But it is said, that the king may dispose of them in his lifetime by letters patent.' The latter prerogative should be abolished.

${ }^{226}$ Royal collections (it is surmised) include matters administered by the Royal Collection Trust as well as the Royal Philatelic Collection.

${ }^{227}$ See M10, pp 441-6. In particular, the wording in the Union with Scotland Act 1706, art 24 is unclear and antiquated. It should be replaced.

${ }^{228}$ Ibid, 446-8. This includes the Great Seal Act 1688, Great Seal (Offices) Act 1874 and the Great Seal Act 1884, Ibid, pp 446-7. See also GS McBain, Legal Documents - Modernising the Formalities (2019) International Law Research, vol 8, no 1, pp 13-4.

${ }^{229}$ Ibid, p 448.

${ }^{230}$ See generally, M1, pp 38-43.

${ }^{231}$ Ibid, pp 40-2.
} 
and its ambit is uncertain. ${ }^{232}$ The use of proclamations should be abolished - save where legislation provides - since Parliament should be in charge of making legislation and not the Crown. Thus, any Crown prerogative should be abolished.

- It may, also, be noted that - in almost all cases where proclamations have been issued in the last 200 years - a Statutory Instrument (SI) would be preferable today;

- Further, factual statements issued by the Palace (such as the announcement of a royal event) should not require a proclamation.

In conclusion, any Crown prerogative to issue a proclamation should be abolished and legislation provide for when a proclamation is required.

\section{TAXATION}

A Crown Act should abolish: (a) any Crown prerogative to tax without the consent of Parliament; (b) clarify the legal position as to payment of income tax by the sovereign. As to these:

\section{(a) Crown Prerogative to Tax-Consent of Parliament}

From early times, English sovereigns sought to tax their subjects, to provide for their upkeep and that of their court. This was resisted by Parliament in medieval times since sovereigns had a large landed estate (the royal demesne) which was designed to provide for their upkeep. As to these early forms of national tax: ${ }^{233}$

- Danegeld. The first English tax is, generally, taken to be danegeld ('geld' being gold). This was a form of war tax first levied in $991 \mathrm{AD}$ (a tax of 2 shillings on every hide of land). It was imposed to pay off the Vikings in order to dissuade them from invading (basically, it was a form of bribe). Danegeld was abolished in 1163, being superceded by hidage (hydage);

- Hidage (Hydage) \& Carucage. This superceded danegeld, being a tax on land for the defence of the realm and other purposes. It was superceded in the reign of Richard I (1189-99) by carucage - a tax levied on every plough (or caruca) which tax was (effectively) replaced in 1224 by tallage;

- $\quad$ Scutage. This was a payment (tax) paid in lieu of military service. It was also called escuage or shield money. It was paid by a tenant-in-chief in respect of the service of knights - the provision of which he owed to the Crown (his own service he could only discharge by way of a fine and not by way of scutage). This tax was imposed by Henry II (1154-89) but it was not assessed after 1315;

- $\quad \underline{\text { Tallage. }}$ This took over from the taxes referred to above. It was compulsory. Sometimes, it was a fixed sum (often, in the case of London). Other times it was a tax on movables or rents. It was imposed on the tenants of the royal demesne (that is lands owned by the sovereign) to contribute towards: (a) the discharge of the debts he incurred for his table (i.e. his food and entertainment expenses); (b) maintaining his army during a military campaign; (c) on the occasion of any unusual expense. Tallage was collected from 1168-1312 (it was mainly used - in this period - for the sovereign to engage in foreign wars). It seems to have fallen into dis-use in 1312 (it was levied, but not collected, in 1332). In part, its extinction resulted from the Statute concerning Tallage (Statutum de Tallagio non Concedendo) 1297 (although the date may be 1306) which Act (still extant) prevented the sovereign levying any tallage (or aid, auxilium) ${ }^{234}$ without the consent of Parliament, something re-enforced by the Bill of Rights 1688, s 1 (still extant, see below). This State tallage should be distinguished from any manorial tallage;

- $\quad \underline{\text { Aids. }}$. As well as tallage (see above), the sovereigns also collected aids (from the latin, auxilium). These were said to be a voluntary form of payment (i.e. a gift) to the sovereign. However, they were (in practice) compulsory. They should be distinguished from manorial aids. Magna Carta 1225 permitted the sovereign to impose 3 types of aid, viz. to: (a) make his eldest son a knight; (b) marry off his eldest daughter; (c) ransom himself from captivity. These forms of tax were of little financial worth after 1350 when the sums for aid that sovereigns could seek was fixed. As it is, (a) and (b) were abolished by the Tenures Abolition Act 1660. Also, anyway, they were (effectively) replaced by another form of tax (subsidies, a Parliamentary tax levied on every subject according to the value of his land and goods) in 1377. As for any other forms of aid, the Statute concerning Tallage 1297 (see above) prohibited them. So did the Confirmation of the Charters 1297, chapter 6 (still extant). ${ }^{235}$ Also, the Bill of Rights 1688, s 1 (see below);

\footnotetext{
${ }^{232}$ Ibid, p 39, n 295 and p 43.

${ }^{233}$ They are discussed in more detail in M2, pp 536-47. Also, in M18.

${ }^{234}$ It states: 'No tallage or aid shall be taken [alternative wording, laid] or levied by us or our heirs in our realm, without the good will and assent of [additional wording, the] archbishops, bishops, earls, barons, knights, burgesses, and other freemen of the land [alternative wording, free commons of our realm].'

${ }^{235}$ It states: 'we have granted for us and our heirs as well as archbishops, bishops, abbots, priors, and other folk of holy church, as also to earls, barons, and to all the commonality of the land, that for no business from henceforth we shall take [additional wording, of our realm] such
} 
Because of this prohibition on the sovereign seeking to impose a tax in the form of tallage or an 'aid', without the consent of Parliament, sovereigns sought to circumvent this by calling such 'loans', 'gifts', 'benevolences' etc. However, the Petition of Right $1627, \mathrm{~s} 8^{236}$ prohibited the exaction of any such without the consent of Parliament. As it was, attempts by sovereigns to impose taxes without the consent of Parliament, effectively, ended by 1660 since the Tenures Abolition Act 1660 abolished most feudal sources of revenue and financed the Crown by means of an hereditary excise on beer and other liquors. Later, the Bill of Rights 1688 (still extant) sought to definitively preclude any attempts by the Crown to tax without Parliamentary consent by stating:

Levying money for or to the use of the Crown by [pretence] of prerogative without grant of Parliament for longer time or in other manner than the same is or shall be granted is illegal. ${ }^{237}$

In 1760, the Crown handed over the Crown demesnes (lands) in return for State (i.e. Parliamentary) funding by way of a Civil List. Thus, all the elderly legislation concerned with the same may be repealed. ${ }^{238}$ Further, the wording in the Bill of Rights 1688 should be modernised to include the Crown's prerogative to levy a common law toll which is now obsolete - tolls being statutory or contractual now (see 8(d)). Thus, a Crown Act should state something to the following effect:

Any Crown prerogative to levy: (a) any form of tax or toll; or (b) the same for a longer time (or otherwise as permitted by legislation), without the consent of Parliament, is abolished.

\section{(b) Sovereign - Paying Income Tax}

At present, the sovereign pays income tax voluntarily on revenue from the duchy of Lancaster.

- One argument adduced for the lack of an obligation to pay income tax is that the sovereign is the source of taxation. While this may have been the case in Norman times, it is not the case today. Indeed, the Bill of Rights 1688, s 1, expressly indicates that the Crown may not tax without the consent (that is, without the authorisation) of Parliament. Thus, in modern times, it is for Parliament to determine this matter, since Parliament is now the source of taxation;

- Further, the Crown was the source of taxation in Norman times, in the body politic (as later Elizabethan jurisprudence would hold) and not in the body personal. Thus, any historical reference to the same is of little use in the case of determining whether the sovereign, today, should pay tax in the body personal.

Also, there is no legal reason why the sovereign should not pay income tax on her other revenues, howsoever earned. Thus, her position should be no different, personally, to that of her subjects. Thus, a Crown Act should, perhaps, state:

The following shall pay income tax, the: (a) sovereign (including in right of the duchy of Lancaster); (b) Duke of Cornwall (including in right of the duchy of Cornwall)(for which see 23).

In conclusion, a Crown Act should provide for:(a) the abolition of any Crown prerogative to impose any tax or toll, without the consent of Parliament; (b) the sovereign to pay income tax (if so determined).

\section{ROYAL ARMS, ROYAL STANDARD, UNION JACK}

It would be useful for a Crown Act to make provision as to the form of the above and their use, in order to clarify the same..$^{239}$ In conclusion, a Crown Act should provide for the form and use of the above.

\section{MILITARY MATTERS}

A Crown Act should make provision in respect of the Crown prerogative: (a) for the sovereign to be commander-in-chief of the armed forces; and (b) in respect of Crown prerogatives relating to: embargoes, blockades, the requisition of ships and prize and bounty. In respect of these:

\section{(a) Sovereign-Commander-in Chief}

From Anglo-Saxon times, the sovereign was also the commander-in-chief of the military. Indeed, until 1743, he, (often) led his soldiers into battle (George II fought at Dettingen in 1743). ${ }^{240}$ Today, although nominally (ex officio) the sovereign is still

manner of aids, tasks, nor prises, but by the common assent of the realm, and for the common profit thereof, saving the ancient aids and prises due and accustomed.' 'Task' (also called a mise) was a general word for a tax. Prises (prisage) were customs duties.

${ }^{236}$ It states: 'no man hereafter be compelled to make or yield any gift, loan, benevolence, tax or such like charge without the common consent by Act of Parliament...' (spelling modernised, italics and commas supplied).

237 'Pretence' means, in effect, 'By asserting a Crown prerogative'. And 'grant of Parliament' refers to the consent of Parliament. See also Chitty (writing in 1820), n 13, p 202 'It is a most important principle of law that the king has no prerogative power of taxing his people: that can only be affected [effected] by Act of Parliament.'

${ }^{238}$ viz. (a) Statute concerning Tallage 1297; (b) Confirmation of the Charters 1297; (c) Petition of Right 1627 (re tax. The provisions in this Act in respect of billeting and martial law can be repealed if s 8(a) is applied in a Crown Act); (d) Free and Voluntary Present to his Majesty 1661.

${ }^{239}$ See generally Halsbury (1st ed), vol 6, pp 361-2. Also, 5th ed, vol 29, paras 46-8.

${ }^{240}$ Chitty, n 13, p 6 'the king is generalissimo of all land and naval forces.' 
the titular head of the armed forces; she has no control over military affairs. This change should be recognised in a Crown Act. It may, also, be appropriate for the sovereign only to hold a military rank and for no other member of the Royal Family to retain the same - if it is thought that the scope of the latter should be reduced (see also 18).

\section{(b) Embargos etc}

A Crown Act should also make statutory provision for certain military Crown prerogatives which - albeit rare - may still occur (or in respect of which there is uncertainty) viz:

- An embargo of civilian ships (and goods in them); ${ }^{241}$

- The blockade of civilian ships, ${ }^{242}$

- The requisition of civilian ships;

- $\quad$ Prize \& Bounty. ${ }^{243}$

As to these:

- Embargo. The word 'embargo' has changed over time. In the $18^{\text {th }}$ and $19^{\text {th }}$ centuries, for legal purposes, it was an expression to refer to the prerogative of the Crown to prevent the import, or export, of goods (whether generally or specifically) into (or out of) the realm. An embargo was only legally permitted in war time or in the case of other national emergency. However, whether the Crown had such as power was questioned even in the $18^{\text {th }}$ century ${ }^{244}$ and Hale concluded that, in peace time, an embargo could not be imposed without legislation. ${ }^{245}$ More recently, the emphasis has been placed, less on the goods, than the manner of import which was by sea (until commercial aviation commenced in 1919). ${ }^{246}$ Today, the term 'embargo' tends to refer more to the arrest (seizure) of civilian ships (and goods) in wartime or other national emergency and it seems appropriate that Parliament should be required to consent to the same, given its draconian nature;

- $\quad$ Blockades of Civilian Ships. These were employed as a military tactic up until World War II. However, given the sophistication of military technology today, they are unlikely to feature much in the future. Nevertheless, it is appropriate that the Crown not undertake the same without the consent of Parliament. Thus, any Crown prerogative should be abolished;

- $\quad$ Requisitioning Ships. This applied mainly up to the end of of World War I (1914-8). However, it may still be required in the case of national emergency. As with embargoes and blockades, it is appropriate the Crown not undertake the same without the consent of Parliament. Thus, any Crown prerogative should be abolished;

- $\quad$ Prize \& Bounty. Prize and bounty (booty) was to encourage naval personnel to seize ships (and armed forces personnel to seize land military equipment) and to receive a financial reward from their sale (also, the Lord High Admiral - a public office that is now a sinecure - was entitled to a reward (droits) as a perk of the office). Such no longer apply. Further, modern ships are more difficult to board (to seize) and it would be difficult (or not worth) taking them before a prize court. Thus, the law should be updated. If prize and bounty were abolished, statutory provision could be made for captured enemy

\footnotetext{
${ }^{241}$ Ibid, p 21 'The king's right to keep his subjects within the realm...either by laying on an embargo, which, however, can it seems be legally done only in time of enmity, and in case of necessity etc'. Ibid, p 50 (quoting Lord Erskine in 1808) 'The king may lay on a general embargo, and may do various acts growing out of sudden emergencies; but in all these cases the emergency is the avowed cause, and the act done is as temporary as the occasion. The king cannot change by his prerogative of war, either the law of nations or the law of the land, by general and unlimited regulations.' Ibid, $\mathrm{p} 50$ 'The king may lay on a general embargo...'.

${ }^{242}$ Ibid, p 48 'his majesty may promúlgate blockades...'

${ }^{243}$ See generally, M17. Also, Halsbury $\left(5^{\text {th }}\right.$ ed), n 17, vol 20, para 186.

${ }^{244}$ Thus, Chitty (writing in 1820), n 13, p 164 refers to a Crown proclamation in 1766 which imposed an embargo of the export of corn in order to prevent famine. An Act of Indemnity (7 Geo III c 7(1766)) asserted that such was illegal and it indemnified the owners of ships and cargoes who suffered economic loss as a result.

245 Thus, Chitty (writing in 1820), n 13, pp 164-5 concluded 'embargoes which occasion a suspension of commercial intercourse, are not legal at common law, except when they operate for the public good and safety; being used in time of enmity and threatened hostilities and on an emergency, and not for the private advantage of a particular trader or company. Nor can a civil embargo, that is, an embargo which is employed in the case of allies and subjects, be imposed upon British ships in a foreign port, unless by the concurring authority of the state to which that port belongs; for the king has no right to disturb the peace of other nations, by any seizures, however useful to the interests of his own people.' ${ }^{246}$ Thus, for example, JS James, Stroud's Judicial Dictionary of Words and Phrases (4th ed, 1972), vol 2 (embargo)(quoting various authorities) 'An embargo is an arrest laid on ships or merchandise by public authority, or an order prohibiting ships from putting to sea, and sometimes from entering ports. It does not put an end to any subsisting contract relating to the ship affected, but is only a temporary suspension of such contract.'
} 
military equipment to be: (a) destroyed; (b) scrapped; (c) disabled; (d) otherwise dealt with by the MOD.

In conclusion, a Crown Act should provide for: (a) only the sovereign to hold an honorary military rank (viz. commander-inchief); (b) the abolition of Crown prerogatives relating to embargoes, blockades, requisitioning ships and prize and bounty.

\section{COMPULSORY ACQUISITION OF LAND}

There are two Crown prerogatives which should be considered:

\section{(a) Compulsory Acquisition - Military Purposes}

The Crown claimed the prerogative to compulsorily acquire (take) the land of subjects for military purposes during war time. However, in Victorian times, detailed legislation superceded this prerogative. ${ }^{247}$ Legislation also provides for the compulsory acquisition of land in other circumstances - including in the case of a national emergency. Thus, provision should be made in a Crown Act for the abolition of the Crown prerogative as unnecessary. A Crown Act, therefore, might state something to this effect:

Any Crown prerogative to compulsorily acquire (or requisition) real property in the UK or in any BOT, whether in peace time or war time, is abolished.

\section{(b) Compulsory Acquisition - Enemy Territory}

The position as to the compulsory acquisition of land in a foreign country which is occupied by a foreign enemy should also be clarified. In particular, whether any compensation should be paid. ${ }^{248}$ Thus, a Crown Act might state something to this effect:

During war time, the Crown may compulsorily acquire (or requisition) real property in a Foreign Country occupied by the enemy without the payment of compensation where such real property is:

(a) occupied by the enemy; or

(b) likely to be occupied by the enemy.

\section{BONA VACANTIA}

The Crown has the prerogative to bona vacantia. This was, sometimes, franchised - such as to the duchies of Lancaster and Cornwall. Bona vacantia is defined by Walker as follows:

Things which no person can claim as property, including wreck, treasure trove, waifs and strays, the property of dissolved corporations, and the residuary estate of persons who have died intestate and without relatives entitled to succeed. It does not cover property lost or abandoned. The Crown has right to all bona vacantia. ${ }^{249}$

This definition reflects the confusion as to the precise meaning of bona vacantia as well as its changing meaning over time ${ }^{250}$ since the medieval concepts of waifs and estrays exist as separate legal concepts without regard to bona vacantia as such. That said, they can be abolished as obsolete (see 27). Wreck and treasure trove are now dealt with by legislation. Further, they are not, generally, classed as bona vacantia now (nor are royal fish). The residuary estate of those who have died intestate, more properly, was termed escheat, arising from the Norman system of land tenure which held the sovereign to be lord paramount. ${ }^{251}$ More properly, bona vacantia refers to the cases where the liquidator of a company (or a trustee in bankruptcy) disclaims freehold land which is onerous. That is to say, either worthless or a burden. ${ }^{252}$ For example, land may be subject to a heavy rent charge (or strict covenants or be polluted or comprise, for example, a dangerous disused quarry). It is asserted that the Crown prerogative to bona vacantia should be abolished. Also, any franchise - since the duchies give their revenue from their

\footnotetext{
${ }^{247}$ Halsbury, n 17, (5th ed), vol 18, para 519 'The right to take land or affect injuriously some or all of the rights of ownership in land, whether by the taking of those rights or their curtailment, was originally a prerogative right enjoyed by the sovereign power in the state [i.e. the Crown], but even in time of war and where the land is required only temporarily the executive prefers to act under statutory authority.' (italics supplied) The word 'requisition' tends to be used only in the context of war or anticipated war.

${ }^{248}$ At common law, the Crown was held not entitled, by virtue of the Crown prerogative, to take possession of a subject's property for reasons of State (i.e. by Act of State) without paying compensation. See Halsbury, n 17 (5th ed), vol 20, para 187. However, compensation is not payable in the case of war damage, see War Damage Act 1965, s 1.

${ }^{249}$ DM Walker, The Oxford Companion to Law (1980)(bona vacantia).

${ }^{250}$ Bona vacantia has always been rather an elastic category. Originally, it only applied to personal property. However, it was extended to freeholds. Also, to the equity of redemption of freeholds. Further, it used to cover treasure trove, estrays and royal fish. However, they are no longer classed as such. See Halsbury (5th ed), n 17, vol 29, para 149, n 1. Also, Chitty (writing in 1820), n 13, p 136.

${ }^{251}$ See McBain, $\mathrm{n} 217$ (first article), pp 97-9.

${ }^{252}$ Ibid, p 98 and Insolvency Act 1986, ss 178 and 315. Some authors view these statutory disclaimers as a form of escheat (e.g. Jessel, Ibid, p 98). However, they are not since escheat was medieval concept arising from Norman land tenure and ss 178 and 315 are statutory.
} 
franchise to charity. Instead, any right to bona vacantia should pass, and be administered by, HM Treasury. ${ }^{253}$ This would cut the bureaucracy involved in the same.

In conclusion, the Crown prerogative to bona vacantia (and any franchise) should be abolished. All bona vacantia (as defined) should pass to HM Treasury.

\section{ROYAL FAMILY \& HOUSEHOLD}

As to these: ${ }^{254}$

\section{(a) Royal Family - His (or Her) Royal Highness}

As previously noted, the royal family does not possess any Crown prerogatives, with limited exceptions (see 8). However, certain members are entitled to use the title 'His (or Her) Royal Highness' ('HRH'). A Crown Act should define the 'Royal Family' and, perhaps, restrict the persons to whom it should apply.

\section{(b) Roval Family - Education of Children}

The sovereign has a Crown prerogative to regulate the education (and custody) of members of the royal family who are minors. ${ }^{255}$ Today, such a prerogative should be limited to those of the royal family (as defined) since such is in derogation of the rights of the parents etc.

\section{(c) Royal Household}

In respect of the royal household, a Crown Act could make provision for the modernisation of the titles of certain household offices. Also, the abolition of others thought to be obsolete. ${ }^{256}$

In conclusion, a Crown Act should define the concept of 'Royal Family' and who is entitled to use the title 'His (or Her) Royal Highness. Also, the prerogative of the sovereign as to the education and custody of the same. Further, provision should be made as to the modernisation of the royal household.

\section{CROWN DECORATIONS, MEDALS \& OFFICES}

\section{(a) Decorations \& Medals}

The Crown, as well as having the prerogative to award titles and honours, has the prerogative to award decorations and medals. Many of these, however, have names that bear reference to the times of the British Empire. Or they apply to long service. However, in the past, this was with reference to persons who spent their entire working life in the employ of the Crown - which is not the same as today. Thus, it may be appropriate to reduce (considerably) a number of these decorations and medals (and, perhaps, end all those relating to long service).

\section{(b) Offices - Sinecures}

The Crown also appoints to many offices that are sinecures now. For example, the Crown appoints high sheriffs and lords lieutenants. ${ }^{257}$ However, both categories no longer perform any legal or military functions as such. There are many others, some with rather exotic or mysterious titles. In modern times - and bearing in mind all the cost and bureaucracy involved some (or all) of these Crown sinecures should be curtailed.

In conclusion, a Crown Act should indicate what decorations, medals and Crown offices may be abolished.

\footnotetext{
${ }^{253}$ The concept of escheat should also be abolished. If the Norman tenurial system is abolished (see McBain, $\mathrm{n} 217$ (first article)), then bona vacantia should also be defined to include any land which is: (a) without an owner; (b) disclaimed by the owner generally (cf. where onerous). Ibid, $\mathrm{p} 99$.

${ }^{254}$ See generally, Halsbury, n 17, (1st ed), vol 6, pp 364-5. Also, Chitty (writing in 1820), n 13, pp 406-7.

${ }^{255}$ Chitty (writing in 1820), $\mathrm{n} 13$, pp 406-7. He noted that this was the subject of an opinion of 12 judges in 1717. See also an opinion of judges in 1772, see Halsbury, n 17, (1 $1^{\text {st }}$ ed $)$, pp 364-5.

${ }^{256}$ See generally, McBain, $\mathrm{n} 218$, pp 51-60.

${ }^{257}$ Ibid, pp 32-40 (high sheriff) and pp 40-3 (lord lieutenant).
} 


\section{GOVERNORS OF BRITISH OVERSEAS TERRITORIES}

For convenience, the Crown delegated certain of its prerogatives to the governors of Crown colonies (now British Overseas Territories). ${ }^{258}$ Such as to assent to legislation. ${ }^{259}$ Or, to pardon (or reprieve) a person. ${ }^{260}$ A Crown Act should make provision for this. It may be noted that - although certain authors such as Chitty called such a delegation a 'franchise' - the word 'delegation' is more appropriate since a franchise, usually, occurred pursuant to the payment of money to the Crown (i.e. it was a revenue exercise) and no payment was made in the case of governors.

In conclusion, a Crown Act should indicate what Crown prerogatives may be delegated to the governors of BOT.

\section{INTERPRETATION OF LEGISLATION}

\section{(a) Crown not Bound}

There is a rule of law that the Crown is not bound by legislation unless referred to expressly or by implication. Thus, Chitty (writing in 1820) stated:

The general rule clearly is, that though the king may avail himself of the provisions of any Acts of Parliament, he is not bound by such as do not particularly and expressly mention him. To this rule...there is a most important exception...that the king is impliedly bound by statutes passed for the public good; the relief of the poor; the general advancement of learning, religion and justice; or to prevent fraud, injury or wrong...But Acts of Parliament which would divest or abridge the king of his prerogatives, his interests or his remedies, in the slightest degree, do not in general extend to, or bind the king, unless there be express words to that effect. ${ }^{261}$

Such should be reflected in a Crown Act. However, consideration, today, might be given to the opposite being stated since, in practice, most legislation (including SI's) do apply to the Crown. And, in a modern democractic society this is appropriate.

\section{(b) $\underline{\text { Successors }}$}

Further, it is a rule of law that reference to the sovereign includes her successors, without having to state this same. ${ }^{262}$ This, also, should be preserved.

In conclusion, a Crown Act should indicate that the Crown is not bound by legislation unless referred to expressly or by implication. Also, that reference to the sovereign includes her 'successors.'

\section{CROWN \& THE CHURCH OF ENGLAND}

The Church of England (the ' $\boldsymbol{C o E}$ ') is a State church, because it is established and regulated by legislation. Not because (as sometimes thought) the sovereign is the head of it. Thus, if the sovereign was no longer the same this would not alter. Over the last 100 years there have been great changes to the $\mathrm{CoE}$ (as well as to society) and many UK citizens are no longer religious or are of different faiths to the CoE. Further, the role of the sovereign in the executive management of the CoE over the centuries has given way to its being, in modern times - a formal role. Much like that in connection with the Church of Scotland. Thus, a Crown Act should make (perhaps) provision in respect of such matters. As to these:

\section{(a) Sovereign as Head of the CoE}

The Act of Supremacy 1533, s 1 provided for the sovereign to be the 'only supreme head' of the CoE. ${ }^{263}$ Although s 1 was repealed by Queen Mary (1553-8), an oath required to be given by the Act of Supremacy 1558,264 s 19 (now repealed) provided that: I [X] do utterly testify and declare in my conscience, that the Queen's highness [i.e. Elizabeth I (1558-1603)] is the only

\footnotetext{
${ }^{258}$ Chitty (writing in 1820), n 13, p 24 'The governors of colonies are in general invested with royal authority; they may call, prorogue, (adjourn) and dissolve the colonial assemblies, and exercise other kingly functions: but they still are the servants or representatives of the king. Prima facie however their acts remain good: and though the king may refuse to confirm, and may revoke the governor's assent to an act of the assembly, it appears that, till revoked, such assent is, generally speaking, effective. And there can be no doubt that though the discretion in passing Acts of Parliament in England is an incommunicable prerogative, it is not so as to acts of assembly, but may be legally communicated to the governor of a colony. The same as to pardoning offenders in the colonies...Nor can there be any doubt that the King may enable the governor to grant Crown lands, franchises and possessions in the colonies. The acts of the governor should be under the great seal of the province, unless an usage e contra can be shewn.'

${ }^{259} \mathrm{Ibid}, \mathrm{p} 74$ 'The discretionary power of assenting or dissenting to an Act of Parliament is, in England, a high and incommunicable prerogative; though it may be communicated to the governor of a colony, with respect to acts of the colonial assembly.'

${ }^{260}$ Ibid, pp 89-90.

${ }^{261}$ Ibid, pp 332-3.

${ }^{262}$ This is predicated on the legal presumption that the Crown (in the body politic, as a corporation sole) never dies. See also 1.

${ }^{263} 26$ Hen 8 c 1 (rep).

${ }^{264}$ It was entitled 'An Act to restore to the Crown the ancient jurisdiction over the Estate Ecclesiastical and Spiritual and abolishing all foreign powers repugnant to the same.'
} 
supreme governor of the realm...(italics supplied).' This is the title by which the sovereign is referred to today ${ }^{265}$ although legislation as such does not specify it. As head of the $\mathrm{CoE},{ }^{266}$ the sovereign:

(i) formerly appoints archbishops and bishops; ${ }^{267}$

(ii) summons (and dissolves) the General Synod;268

(iii) gives assent to Measures - to enable them to take effect;

(iv) grants licences (and dispensations) under the Ecclesiastical Licences Act 1533. ${ }^{269}$

Hill summarised the role of the sovereign thus:

The sovereign acting according to the laws of the realm is the highest power under God in the kingdom and, since the Settlement Act 1701, must be in communion with the [CoE]. The sovereign is not a minister of the word of God nor of the sacraments, but is supreme Ordinary and visitor and exercises certain powers formerly vested in the pope, such as the granting of licences and dispensations under the Ecclesiastical Licences Act 1533. Significant rights of patronage vest in the sovereign, including the appointment of all bishops and archbishops. ${ }^{270}$ (italics supplied)

However, the title 'supreme governor' is a misnomer since the sovereign does not govern the CoE and the executive head has long been recognised as being the Archbishop of Canterbury (the 'AoC'). Thus, today, the sovereign's role in respect of the $\mathrm{CoE}$ is a formal one - acting under advice and not pursuant to a personal exercise of judgment. Further, the sovereign is not exercising her power in the body natural as head of the CoE when, for example, assenting to Measures. Rather, her capacity is that of the Crown in the body politic. Also - in the case of opening and dissolving the General Synod - the role of the sovereign, today, is akin to her position with the Church of Scotland (' $\mathbf{C o S}$ '), rather than as head of the CoE. Thus, this - and the other roles stated in (i)-(iv) above - could be assumed by the AoC who has long been recognised as de facto head of the $\mathrm{CoE}$ (or in the case of formally appointing archbishops, for example - such power could now be exercised by the General Synod). ${ }^{271}$

In conclusion, the role of the sovereign as head of the CoE was important in times past. However, today, the sovereign's role, in general, is a formal and ceremonial one - including in relation to the CoE. Further, the sovereign may have no interest, in person, in the CoE. That is, the sovereign may wish to belong to another religion (or, indeed, to none at all) and it would not seem appropriate - in modern times - for the sovereign to be excluded from this basic human right. ${ }^{272}$ Legally, abolishing her role as 'supreme governor' (head of the church) would not be difficult since it would involve little change to (i)-(iv). Further, ending this role would not, per se, end the status of the $\mathrm{CoE}$ as a church established (by legislation). Nor as a 'State' church (as some might still like to call it). However, it might help the CoE to adapt to the modern world where society in general and, possibly, some (or many) in the $\mathrm{CoE}$ - would prefer religion to be less closely allied to the State, given its troubled history in Tudor times and around the world presently.

In conclusion, a Crown Act should specify who is head of the CoE - the sovereign or the AoC.

\section{(b) Appointment of Archbishops \& Bishops}

If the role of the sovereign changed (see (a)), legislation could specifiy who should appoint archbishops and bishops in place of their formal appointment by the sovereign. Such could, then, reflect the current role of the General Synod which is the legislative (and overall,executive) vehicle of the CoE. For example, if a Crown Act were to provide:

(1) The appointment of (as well as any resignation or dismissal of) any:

\footnotetext{
${ }^{265}$ The canons of the CoE refer to this role. Thus: 'A1 (of the Church of England) 'The [CoE], established according to the laws of this realm under the Queen's majesty...A6 (Of the Government of the Church of England) 'The government of the [CoE] under the Queen's majesty...A7 (Of the Royal Supremacy) 'We acknowledge that the Queen's excellent majesty, acting according to the laws of the realm, is the highest power under God in this kingdom, and has supreme authority over all persons in all causes, as well ecclesiastical as civil.'

${ }^{266}$ The Act of Supremacy 1558, s 8 (the head note is 'All spiritual jurisdiction united to the Crown'), which is still extant, states, with the spelling modernised: 'such jurisdictions privileges, superiorities and pre-eminences spiritual and ecclesiastical, as by any spiritual or ecclesiastical power or authority has heretofore been or may lawfully be exercised or used for the visitation of the ecclesiastical state and persons and for reformation, order and correction of the same and of all manner of errors, heresies, schisms, abuses, offences, contempts and enormities, shall forever by authority of this present parliament be united and annexed to the imperial crown of this realm. (commas added).

${ }^{267}$ See M Hill, Ecclesiastical Law (OUP, 2018), p 4 and L Leeder, Ecclesiastical Law Handbook (1997), p 13.

${ }^{268}$ HW Cripps, Practical Treatise on the Law relating to the Church and Clergy (8th ed, 1937), p 3 'In virtue of his authority as supreme head of the church, the sovereign convenes [i.e. convokes], prorogues, restrains, regulates and dissolves all ecclesiastical synods or convocations.'

${ }^{269} \mathrm{Hill}, \mathrm{n} 267, \mathrm{p} 10$ noted that the Bill of Rights 1688, s 1 provides that the sovereign does not have a general power to dispense from the laws ecclesiastical.

${ }^{270}$ Ibid, p 10.

${ }^{271}$ The need for any royal assent to Measures to give them effect could be dispensed with, the General Synod holding that Measures come into effect on promulgation (or on the date stated in the Measure etc).

${ }^{272}$ See Human Rights Convention, art 14 (prohibition on discrimination on the grounds of religion etc).
} 
(a) archbishop shall be made by the General Synod;

(b) bishop shall be made by the Archbishop of Canterbury;

(c) other person to any ecclesiastical office shall be made by the diocesan bishop, save where a Measure provides otherwise.

\section{(c) Coronation Oath}

Prior articles have analysed this in detail. ${ }^{273}$ In particular, the following may be noted. Presently, the sovereign must endorse the $\mathrm{CoE}$ (and the $\mathrm{CoS}$, to a lesser extent) in certain respects. These are, in summary, as follows:

- $\quad$ Accession. The sovereign must declare - on accession - him (or her) self to be a 'faithful protestant';

- $\quad$ Communion. The sovereign must join in communion with the CoE;

- $\quad$ Coronation Oath. The sovereign must give a coronation oath. One in which he (or she) promises to maintain: (i) the laws of God; (ii) the true profession of the Gospel; (iii) the protestant reformed religion established by law. Also, to maintain and preserve: (iv) the settlement of the $\mathrm{CoE}$ and its doctrine, worship, discipline and government, by law established; and (v) the legal rights and privileges of the bishops and clergy of the CoE (and their churches);

- $\quad$ Oath - Church of Scotland. The sovereign must swear to maintain the CoS;

- $\quad \underline{\text { Title. }}$. The sovereign bears the title 'Defender of the Faith' - a title originally given to Henry VIII (1509-47) by a Catholic pope. ${ }^{274}$

Since the $\mathrm{CoE}$ is an established church - that is, one established by law - it is unsurprising these obligations arise from legislation. However, despite this, they are not actually legally enforceable. That is, the sovereign cannot be sued in respect of such affirmations or oaths - including any failure to perform the same. Not least, since she is not cognisable in her own courts. ${ }^{275}$ Also, such obligations are very opaque in nature. After all, what does a 'faithful protestant' mean ? ${ }^{276}$ Does 'communion' mean regular attendance at a CoE church - or simply adhering to the tenets of the same ? ${ }^{277}$ How does the sovereign maintain the laws of God and the true profession of the gospel - especially in the capacity of her body politic, as opposed to any personal adherence? What exactly does 'maintain' mean ? Legally uphold ? Morally uphold ? Personally uphold? How exactly does the sovereign 'defend' the Faith? To whom does the 'protestant reformed religion established by law' refer to ? Just to the $\mathrm{CoE} ?{ }^{278}$ None of these issues have been legally explored in practice, despite such being (as with all legislation) the outcome of political debate, argument and concession.

If the sovereign is no longer head of the CoE (see (a)), it would seem apposite that all the above requirements vis-à-vis the $\mathrm{CoE}$ be dispensed with since they are, implicitly, predicated on the sovereign being head. However, even if the sovereign remains as head of the church, consideration should be given whether all (or any) of these oaths and affirmations (including in respect of the $\mathrm{CoS}$ ) are necessary. Especially, when they are not legally binding. And, when the sovereign has no input in legislation today. Nor, the power to stop it. Also, where (unlike in the past) the General Synod has the power to legislate - and to alter - the legal rights and privileges of the CoE. Further, choice of religion (or not) is a basic human right and - in modern times - it would seem unduly onerous to require the sovereign to be a member of the CoE when, personally, he (or she) has no interest in the same. In conclusion, consideration might be given to the excision of the above (i.e. of the religious content) from the coronation oath. Also, returning to the simpler language of Anglo-Saxon times in respect of the other parts of the coronation oath. Thus, a Crown Act might provide for the following:

Declaration to be delivered by the archbishop or bishop: 'Do you promise to govern the peoples of the United Kingdom of Great Britain and Northern Ireland, Canada, Australia, New Zealand and your other territories according to their respective laws and customs ?' Sovereign: 'I promise.' Do you promise to cause law and justice to be executed in all your judgements?' Sovereign: 'I promise.'

\footnotetext{
${ }^{273}$ See genearlly, M6.

${ }^{274}$ Ibid, p 3. For the title, 'Defender of the Faith', see p 27. This title was confirmed by the Act for the Ratification of the King's Majesty's Stile ( 35 Hen $8 \mathrm{c} 3$, rep), which also referred to the king as supreme head.

${ }^{275}$ See n 217 (second article), pp 25-31. Today, any legislation can supercede the oath and the sovereign cannot prevent such in reality.

${ }^{276}$ See M6, p 7. Various sovereigns were protestant although not members of the CoE, Ibid. Today, it is likely that all of the coronation oath and other affirmations etc refer only to the CoE, see Ibid, p 10 and, then, p 14 (advice of Kenyon CJ given to George III in 1795).

${ }^{277} \mathrm{Ibid}, \mathrm{p} 16$ (probably, today, this means that the sovereign must be a member of the CoE, although certain sovereigns post-1688 were not).

${ }^{278}$ See n 217 (second article), pp 28-9.
} 


\section{(d) Patronage \& Powers of Appointment ${ }^{279}$}

After the Norman Conquest 1066 (if not before) the method of land holding in England tended to be that of manors. That is, large estates owned by the lord (dominus) of the manor. ${ }^{280}$ The lord of the manor, often, built - or contributed to the building of - the church and, as such, sought the privilege of appointing the priest. Hence, the rise of laymen advowsons and other rights of patronage. That is, the right to appoint (to 'present') a person to an ecclesiastical position - including to an ecclesiastical benefice. Such rights, as well as being held by laymen, were also held by the Crown. Sweet (in 1882) defined an 'advowson' as follows:

Advowson is the right of presenting to a rectory, vicarage or other ecclesiastical benefice whenever it is vacant. It may belong to a private person, or a bishop or other dignitary, or to the Crown. An advowson belonging to the bishop of the diocese is technically the right of collation; some advowsons are called donatives, and a few (such as benefices attached to cathedrals) are elective; an ordinary advowson is sometimes called, by way of distinction, a presentative advowson. An advowson is an incorporeal hereditament, and is either appendant or in gross. ${ }^{281}$ (italics supplied)

Layman, such as lords of the manor also, sometimes, had powers to appoint to other ecclesiastical offices, such as to appoint the sexton or a churchwarden. As it is, history shows that both lay and Crown appointments tended to (often) be divisive, with appointments being made on partisan grounds as opposed to the appointee being the most suitable person in terms of spirituality and personality. The law on patronage and advowsons was (considerably) simplified by the Patronage (Benefices) Measure 1986. ${ }^{282}$ Hill noted:

Patronage is the right to present a cleric to a benefice and is in itself a form of property which may be transferred from one person to another, although it may not be sold. A definite register of the patrons of every benefice is maintained in each diocesan registry where every transfer of a right of patronage is registered...Rights of patronage may also be transferred by pastoral scheme or order...If the patron is an individual and not a clerk in holy orders, he must make a declaration that he is an actual communicant member of the $[\mathrm{CoE}]$ or appoint someone in his place who is a clerk in holy orders, or being a layman, is able to make a declaration of membership... ${ }^{283}$

Many lords of the manor are not members of the CoE. Or - even if so - they are dis-interested in any rights of patronage. It may, also, be noted that the title of 'lord of the manor' can be held in gross, today. That is, without acquiring any land holding. Further, such title can be bought - there being a market in such things. Thus consideration may be given to abolishing all lay rights of patronage, including those held by the Crown. ${ }^{284}$ Indeed, it may be appropriate to go further and provide that appointments to all ecclesiastical positions (including those such as churchwardens and sextons) should only be made by clerics - such as the diocesan bishop (i.e. abolishing all rights of advowson and patronage). In this respect, reference may be made to 'non-parochial units' as termed by Hill who referred to:

- $\quad$ Peculiars. In these, the diocesan bishop is not the Ordinary. Thus, the place is not under the control of the bishop not is it visitable by him. For example, Westminster Abbey and St George's Chapel are royal peculiars; the dean and chapter of each is the Ordinary and they are visitable only by the Crown. Others include royal residences, the Temple, the Oxford and Cambridge universities and certain colleges therein;

- Colleges, Hospitals, Armed Forces \& Guild Churches. The powers of the diocesan bishop, as Ordinary, may not apply to a lesser or greater extent in such cases. There are also 16 City of London guild churches regulated by the City of London (Guild Churches) Act 1952. Such have no parish but do have a 'guild vicar' as well as their own guild clerk, churchwardens and electoral roll. ${ }^{285}$

In conclusion, a Crown Act might consider the abolition of all Crown rights (prerogatives) in respect of patronage relating to the CoE. Indeed, it might go further and abolish all rights of patronage and, instead, specify that the diocesan bishop shall exercise all powers of appointment in respect of clerical appointments, save where otherwise stated (however, such would require the consent of the $\mathrm{CoE}$, since the same does not relate to the sovereign or the Crown, as such).

\footnotetext{
${ }^{279}$ For texts on advowsons, see J Doderidge, Compleat Parson or Description of Advowsons or Church Living (1 $1^{\text {st }}$ ed, 1630, last ed, 1641), J Doderidge, Reading of Advowsons (1663), J Mirehouse, Law of Advowsons (1824), Z Cawdrey, Discourse of Patronage (1675). See also Halsbury (4th ed), n 17, vol 34, para 550 et seq.

${ }^{280}$ See McBain, 217 (first article).

${ }^{281} \mathrm{C}$ Sweet, A Dictionary of English Law (1st ed, 1882)(advowson). It continues 'Etymology. Norman French: avoweesoun. Medieval latin, advocatio, apparently from advocatus, the patron or person who was bound to defend and protect the rights of the church.'

${ }^{282}$ See Hill, n 267, p 107 et seq. This measure made any advowsons appendant ones in gross. See Halsbury (4th ed), n 17, vol 34, para 55.

${ }^{283}$ Ibid, pp 107-8.

${ }^{284}$ Halsbury (4th ed), n 17, vol 34, para 558 'Besides possessing the patronage of certain benefices in right of the Crown or of the duchy of Lancaster, or of the duchy of Cornwall where there is not a Duke of Cornwall of full age, the sovereign is patron paramount of all the other benefices...' However the Patronage (Benefices) Measure 1986 s 32 has abrogated former rules save in very restricted circumstances.

${ }^{285}$ Hill, n 267, pp 96-7.
} 


\section{(e) Religion of the Sovereign}

If a Crown Act abolishes common law Crown prerogatives - especially, those relating to the CoE (in particular), then, consideration may be given to removing any catholic religious limititation on the sovereign. The reason why is clear. In the time in which it was enacted - in the reign of James II (1685-8) who was a catholic - there were deep concerns (whether founded or not) that he was seeking to change the status of the CoE into that of a catholic church, using his influence as sovereign and head of the CoE. Thus, the Bill of Rights 1688 introduced a novel provision in respect of succession to the Crown. It prohibited the sovereign from being a catholic. It stated:

whereas it hath been found by experience that it is inconsistent with the safety and welfare of this protestant kingdom to be governed by a popish prince... the said Lords spiritual and temporal and Commons do further pray that it may be enacted that all and every person and persons that is are or shall be reconciled to or shall hold communion with the see or church of Rome or shall profess the popish religion... shall be excluded and be for ever incapable to inherit possess or enjoy the Crown and government of this realm and Ireland and the dominions thereunto belonging or any part of the same or to have use or exercise any regal power authority or jurisdiction within the same and in all and every such case or cases the people of these realms shall be and are hereby absolved of their allegiance and the said Crown and government shall from time to time descend to and be enjoyed by such person or persons being protestants as should have inherited and enjoyed the same in case the said person or persons so reconciled holding communion or professing....as aforesaid were naturally dead. (italics supplied)

As previously indicated, at the time of its introduction, there were concerns that James II might regain the throne and, later, that his son or grandson might. Such attempts were not to end until after the Battle of Culloden in 1745 when the Stuart challenge to Hanoverian rule ended. Thus, various later pieces of Scots legislation (see below) repeated the provision in the Bill of Rights 1688. However, by 1800, the fear of a Stuart return had ended. Thus, Irish legislation (see below) referred to succession but did not re-state the provision against the sovereign being a catholic in the Bill of Rights 1688 as such. As to these:

- $\quad$ Act of Settlement 1700 'Provided always and it is hereby enacted that all and every person and persons who shall or may take or inherit the said Crown by virtue of the limitation of this present Act and is are or shall be reconciled to or shall hold communion with the see or church of Rome or shall profess the popish religion...shall be subject to such incapacities as in such case or cases are by the said recited Act provided enacted and established [i.e. the Bill of Rights 1688, see above].'

- $\quad$ Act of Union with Scotland 1706 'that all papists... shall be excluded from and for ever incapable to inherit possess or enjoy the imperial Crown of Great Britain and the dominions thereunto belonging or any part thereof and in every such case the Crown and government shall from time to time descend to and be enjoyed by such person being a protestant as should have inherited and enjoyed the same in case such papist... was naturally dead according to the provision for the descent of the Crown of England made by another Act of Parliament [i.e. the Bill of Rights 1688].'

- $\quad$ Act of Union with England 1707 ' that all papists and persons marrying papists shall be excluded from and for ever incapable to inherit possess or enjoy the imperial Crown of Great Britain and the dominions thereunto belonging or any part thereof and in every such case the Crown and government shall from time to time descend to and be enjoyed by such person being a protestant as should have inherited and enjoyed the same in case such papists or person marrying a papist was naturally dead according to the provision for the descent of the Crown of England made by another Act [i.e. the Bill of Rights 1688].'

- $\quad$ Act of Union with Ireland 1800 'that it be the second article of union, that the succession to the imperial crown of the said [UK], and of the dominions thereunto belonging, shall continue limited and settled in the same manner as the succession to the imperial crown of the said kingdoms of Great Britain and Ireland now stands limited and settled, according to the existing laws, and to the terms of union between England and Scotland.' [i.e. according to the Bill of Rights 1688 and the Acts referred to above]

- $\quad$ Act of Union (Ireland) Act 1800. "that it be the second article of union, that the succession to the imperial crown of the said [UK], and of the dominions thereunto belonging, shall continue limited and settled in the same manner as the succession to the imperial crown of the said kingdoms of Great Britain and Ireland now stands limited and settled, according to the existing laws, and to the terms of union between England and Scotland.' [i.e. according to the Bill of Rights 1688 and the Acts referred to above].'

Today, the prohibition on the sovereign being a catholic would - in the case of a subject - (clearly) seem to breach human rights legislation, being the Human Rights Act 1998 which embodied into law the terms of the EU Convention on Human Rights. Further, it results in rather an anomalous situation in that the sovereign can have no religious belief (that is, be an atheist) or any other religious belief (e.g. be a moslem, jew etc) but not be a catholic. Since the fear engendering the provision in 1688 was that the sovereign might - using his power as head of the $\mathrm{CoE}$ - change the same, then, if the sovereign is no longer 'Supreme Governor' of the CoE, the basis of this concern no longer exists (even more so, if all powers of patronage are 
dispensed with). Suffice to say that the prohibition on the sovereign being a catholic could be excised from legislation readily - by excising the reference in the Bill of Rights 1688 and attendant Acts. However, given that - if a simple repeal was effected without more - there may be uncertainly as to the position of the sovereign concerning any other religion, it may be useful to expressly provide that the religion of the sovereign is a private matter for the same.

- Finally, it may be noted that the Succession to the Crown Act 2013 repeals a prohibition on the consort to the sovereign being a catholic. This may be repealed, if the above is effected. Also, $\mathrm{s} 3$ of this Act deals with the consent of the sovereign to certain marriages. This section may be inserted into a Crown Act - enabling the Act of 2013 to be wholly repealed.

In conclusion, a Crown Act might specify that the religion of the sovereign is a private matter for the same - repealing the above legislation.

\section{DUCHY OF CORNWALL}

A Crown Act should, also, make provision for the duchy of Cornwall (the 'DOC') since this estate is held by the Crown on behalf of the nation (i.e. the sovereign in its body politic). In respect of this: ${ }^{286}$

(a) Charters

The DOC, at present, is governed by much antiquated legislation. This comprises, in particular, 3 charters and a writ viz. a:

- charter of 17 March 1337 from the Crown to the duchy;

- $\quad$ charter of 18 March 1337 from the Crown to the duchy;

- charter of 3 January 1338 from the Crown to the duchy;

- $\quad$ writ under the Privy Seal of 9 July 1343 relating to the duchy.

The charter of 17 March 1377 is treated as an Act of Parliament. There is, also, more modern legislation still extant, viz.

- Duchies of Lancaster and Cornwall (Accounts) Act 1838;

- Duchy of Cornwall Act 1844;

- Duchy of Cornwall (No 2) Act 1844;

- Duchy of Cornwall Management Act 1863;

- Duchy of Cornwall Management Act 1868;

- Duchy of Cornwall Management Act 1982.

All of the above charters should be cancelled since they contain obsolete material. Further, in some cases, the wording is uncertain. As for the legislation - which, mainly, deals with the management of the DOC estate - this, also, contains much obsolete material. Further, it is couched in an antiquated Victorian language. Thus, all the above should be placed in a Crown Act (with accounts and management provisions in a Schedule or a SI since they are administrative in nature). This would not be difficult.

\section{(b) Estate \& Inheritance}

Originally, the DOC comprised some 17 manors which were granted in 1337 to the first duke (the Black Prince, the eldest son of Edward III, when he was seven years old). A number of these manors ( 6 of them) were, later disposed of and, over the centuries, other land and property has been acquired. The duke does not ' $o w n$ ' the duchy land. It is not his private property. His is only a life interest. Further, both the estate, and the title of Duke, cannot be alienated (i.e. sold off) - save where legislation permits. The owner of the duchy (that is, of the 'fee simple', as expressed in older times, prior to the Law of Property Act 1925) is the Crown. And, this reference is to the sovereign in her body politic not her body personal. That is, the duchy is not the Queen's private property either. Thus, like the duchy of Lancaster, ownership of the DOC lies with the nation (i.e. in the body politic of the sovereign). A Crown Act should provide for this. Also, the charter of 17 March 1337 (which was in latin) was not very precise as to the mode of inheritance of the DOC - bar the fact that the duchy went to the eldest son (daughters did not count). However, later interpretation by the courts and legal writers has clarified that:

- $\quad$ if there is no eldest son, the sovereign retains the duchy (and title);

- the eldest son inherits the duchy (and title) automatically on birth - providing his parent is sovereign at the time (otherwise, he has to wait until his parent becomes sovereign);

- $\quad$ if the eldest son dies without issue, the duchy (and title) revert to the sovereign unless there is a second son - in which case he takes;

\footnotetext{
${ }^{286}$ See generally, M13.
} 
- $\quad$ if the eldest son dies with issue - because the latter's eldest son is not heir to the throne - the duchy (and title) reverts to the sovereign.

A modern Act should clarify these rules of inheritance. Further - since inheritance to the Crown is now gender neutral - so should inheritance of the duchy be.

\section{(c) Prerogatives}

The charters of 1337 gave to the Duke various Crown franchises (that is, the right to enjoy certain Crown prerogatives). However, these are of no (or scant) worth today. They comprise a right to:

- ' 'royal fish' (whales and sturgeon). This right is no longer availed of today (both are protected species);

- treasure trove - although this is somewhat dubious and not often exercised;

- $\quad$ wreck (also, flotsam, jetsam and ligan). This is of scant worth and not usually availed of;

- $\quad$ bona vacantia and escheat. These sums (which are small) are donated to charity by the duchy;

- $\quad$ gold and silver mines. This is not of great value;

- $\quad$ appoint a high sheriff in Cornwall (a ceremonial post);

- $\quad$ appoint Church of England priests to various churches, abbeys, priories, hospitals and chapels in Cornwall (this right of patronage (the advowson) is not of financial worth).

None of these rights are of much import and all could be relinquished without much economic loss. There are also various other rights, now long obsolete. ${ }^{287}$ A Crown Act should abolish the above, so that the general law applies.

\section{(d) Income Tax}

At present, the Duke pays income tax voluntarily on his DOC income. Two arguments have been adduced for the his nonpayment of income tax. viz.

- $\quad$ Not a Subject. It is said that the duke is not a subject of the sovereign. This is so when the duke is holding qua sovereign but not otherwise. The duke (when a distinct person) must be the subject of the sovereign since English law only recognised (and recognises) 2 categories of person for the purpose of the legal obligation of allegiance. That is: (a) British subjects ${ }^{288}$ (who owe allegiance - and who commit high treason pursuant to the terms of the Treason Act 1351 if they breach it); and (b) aliens (i.e. foreigners, who have no legal obligation of allegiance but who are treated as enemies, if they conduct war against the sovereign).

The Duke is definitively a subject of the sovereign since he owes allegiance to the same. For example, if the Duke kills (or conspires to kill) the sovereign, he commits high treason (the same as a consort) under the Treason Act 1351 since there are no exceptions provided for. Further, the fact that the first Duke was girt with a sword (and cap) in 1337 in Parliament indicates the nature of the allegiance (knight's service) for which the duke will have done homage - just as he did (and does) qua Prince of Wales (a higher title than duke which the heir to the throne also holds). Knight's service, and the homage done for it, is a classic example of a person being a subject of the sovereign and not an alien;

- No mention in Duchy charters. Another argument adduced is that the duchy charters make no reference to taxation. However, nor do other old charters since income tax was only first levied in 1799. Further, the fact that the Duke may not have paid tallage (an early form of tax by the Crown on its demesnes (estates)) does not mean that the Duke should be exempt from income tax. For example, the citizens of London did not pay tallage after 1314. However, they pay (and have paid) income tax.

As with the income tax position of the sovereign (see 13), the income tax position of the Duke should be clarified in a Crown Act. It should be no different to that of any other person.

(e) Mining

In the case of the duchy there are two anomalies it may be useful to address:

- $\quad$ Tin Bounding. The first relates to mining. Since ancient times, tin was worked in Cornwall and there developed certain rights for individuals who worked tin seams (they were also called 'tin bounders'). Over time, certain tin bounding customs developed which modified the general law that the ownership of a mine was vested in the owner of the freehold. Under the customs, if a tin mine within manorial waste (or certain enclosed land) was not worked by the land owner, a tinner could claim a grant (if certain conditions were satisfied) to work the bounds (i.e. to mine the tin in a specified area delineated by stones or turves placed by the tinner). The grant carried an exclusive right to

\footnotetext{
${ }^{287}$ Ibid, pp 47-50.

${ }^{288}$ Also, naturalised persons and those entitled to local protection.
} 
mine all tin ore in that area, subject to paying a royalty (called 'toll tin' or tin toll) to the owner of the land. Laws were made by the miners at convocations (assemblies) to regulate the rights, duties and liabilities of the same. However, all this is now obsolete (and the last convocation met in 1753);

- Conventionary Tenants. Further, in medieval times, peasants (villeins) working the land in the 17 manors comprising the original duchy, gradually, acquired a legal right to occupy the land. This was in the form of a perpetually renewable lease, renewable every 7 years. These tenants were called conventionary tenants (similar to copyholders, but holding by way of lease). Since they were leaseholders, the duke could mine on land they occupied without their consent. 6 manors were later sold (in 1797 under the provisions of the Land Tax Redemption Act). The Duchy of Cornwall (No 2) Act 1844 (also, called the Assessionable Manors Act 1844) laid down mining rules. In particular, the duke retained the right to mine in the unsold manors without consent (1844 Act, s 53, the conventionary tenants holding by way of lease only) - subject to certain restrictions.

Since tin mining no longer occurs in Cornwall (the last tin mine closed in 1998) and individuals working tin seams (i.e. tin bounding) ended long ago and the duchy, in practice, has not sought to exercise its rights in respect of the assessionable manors (likely, for economic reasons as well as the environmental impact) it may be a good time to abolish all of this and let the general law on mines apply.

\section{(f) Foreshore}

Generally, the Crown owns the foreshore and, as such, has a right to mine the same. In Cornwall, however, an Act - the Cornwall Submarine Mines Act 1858 - (effectively) resulted in the duchy owning 3/5ths of the Cornish foreshore (although some appears to have been, subsequently, disposed of). Also, the fundus (i.e. the bed) of certain rivers. The 1858 Act also provided for certain rights of access to the foreshore by the Crown, for mining the bits it owns. Since the historical position is anomalous - and the likelihood of mining the Cornish foreshore in the future is low (for economic and environmental reasons) - it may be useful to repeal the 1858 Act and to re-transfer the foreshore to the Crown. Perhaps, with the DOC, also, providing by way of contract (not legislation) with the Crown Estate for a royalty, if the latter subsequently mine the transferred part. This would simplify things and enable the general law to apply re mining and access on duchy land (it could, also, be transferred on the basis that no mining be permitted on the transferred foreshore in future for environmental reasons).

In conclusion, a Crown Act should make provision in respect of the DOC.

\section{DUCHY OF LANCASTER}

A Crown Act should, also, make provision for the the duchy of Lancaster (the 'DOL') since this estate is held by the Crown on behalf of the nation (i.e. in its body politic). In respect of this: ${ }^{289}$

\section{(a) Estate}

The DOL is an estate of some 40,000 acres. It was a county palatine in 1267 and its status was augmented into that of a duchy in 1351. In 1399, it was not absorbed into the Crown when the Duke of Lancaster became Henry IV (1399-1413). Instead, it remained separate from the Crown, often, being described as an 'appanage' and this was confirmed in 1485 when an Act of Parliament provided that the duchy would pass to Henry VII (1485-1509) and his heirs for ever. Today, it seems clear that the duchy is held on behalf of the nation. That is, by the sovereign in her body politic (as opposed to her body personal). Thus, it is inalienable - albeit, the title of Duke is not and - unlike the title of Duke of Cornwall - it can be passed separate to the duchy.

\section{(b) County Palatine \& Duchy}

In respect of the abolition of the title of county palatine, see $\mathbf{8}(\mathbf{j})$. The duchy itself has no substantive privileges (and none are of economic worth). As to these:

- Bona Vacantia \& Escheat. These are given by the duchy to charity;

- $\quad$ High Sheriffs \& Lords Lieutenant. The duchy may appoint these ceremonial officers in the ceremonial counties of Greater Manchester, Merseyside and Lancashire;

- $\quad$ Advowsons. The sovereign (qua Duke) holds $42 \mathrm{CoE}$ advowsons (only one in the duchy);

- $\quad$ Attorney-General. The duchy has right to appoint such.

Thus, consideration should be given to the abolition of the DOL and, perhaps, the transfer of its real and personal property to the Crown Estate - thereby, saving time and money as well as excising much antiquated legislation. ${ }^{290}$

In conclusion, a Crown Act should make provision in respect of the DOL.

\footnotetext{
${ }^{289}$ See generally, M12.

${ }^{290}$ Ibid, p 16, viz. Duchy of Lancaster Acts 1779, 1787, 1808, 1812, 1817, 1920 and 1988. Also the Duchy of Lancaster (Accounts) Act 1838 and the Duchy of Lancaster Lands Act 1855.
} 


\section{PRIVY COUNCIL}

The Act of Settlement 1700 (still extant) provides (with the spelling modernised) that:

no person born out of the kingdoms of England Scotland or Ireland or the dominions thereunto belonging although he be made a denizen (except such as are born of English parents) shall be capable to be of the privy council... ${ }^{291}$

This provision needs to be modernised. It should not refer to where a person is born or their parentage but whether they are a British citizen (that is, a British subject or naturalised) or not. A privy council member is also required to give an oath. ${ }^{292}$ This involves an official oath, an oath of secrecy and an oath of allegiance. It is suggested that only an oath of secrecy should be required today and that the others (which are not legally binding) should be dispensed with (further, allegiance under English law does not depend on a person having given an oath or not). Also, the same should be in the form of a declaration which to save time - would be easier if signed by each member when they inscribe the privy council's book. Further, a Crown Act should contain section 1 of the Clerk of the Council Act 1859, with the wording using modern terminology.

In conclusion, a Crown Act should make provision in respect of membership of the privy council and any oath (declaration) required to be given.

\section{CHARTERS - CINQUE PORTS, CITY OF LONDON etc}

From an early date the Crown franchised a number of its Crown prerogatives to the Cinque Ports ${ }^{293}$ and to the City of London. ${ }^{294}$ However, these prerogatives are palpably obsolete in most cases. As to these:

- $\quad$ Cinque Ports. These ports were granted various Crown prerogatives in charters dating from 1278-1668, in return for ship service (for defense purposes). However, the latter ended by the 1588 (6 ships supplied for the Spanish Armada) and all these charters are long obsolete;

- $\quad$ City of London. Like the above, the City of London is governed by c. 64 charters, the last of which was in 1741 (more than 260 years ago). All this material is obsolete (and of no financial benefit to the CoL). There is no indication that the $\mathrm{CoL}$ are unaware this material is obsolete and that they would object to the cancellation of all $/$ most of these charters.

Crown prerogatives were also franchised to many boroughs and towns. As to these:

- Boroughs. Generally, boroughs were abolished by the Local Government Act 1972 (in Scotland, burghs were abolished in 1975). However, London boroughs still remain and they may be governed by old charters whose provisions are obsolete. Abolishing the concept of a 'borough' would, per se, cancel the same;

- $\quad \underline{T o w n s}$. Many towns may also be governed by charters (although the issue of the same after 1688 became more rare). A review of these would, almost certainly, provide for their cancellation - whether in whole or part.

In conclusion, a legal expert should be requested to write a (short) report on the Cinque Ports and City of London charters (if required). ${ }^{295}$

- $\quad$ Bodies Corporate \& Others. Finally, all bodies corporate or other persons (legal or individual) who hold Crown charters should be required to submit by a specified date details of any Crown charter granted to them - for a legal expert appointed by the government to determine whether any provisions of the same are worth retaining.

In conclusion, a Crown Act should cancel Crown charters save where any provisions need to be preserved in an SI (which is unlikely in the case of the Cinque Ports, the City of London, counties corporate, boroughs and towns).

\section{ROYAL FISH, WAIFS \& ESTRAYS}

There are certain legal concepts which are now obsolete and which should be abolished in a Crown Act. Thus:

- $\quad \underline{\text { Roval Fish }}$. These are referred to in the Act, Prerogativa Regis (c. 1272-3). Even if the Act is repealed, it is possible that 'royal fish' may include porpoise, narwhals etc. ${ }^{296}$ Thus, this concept should be abolished generally;

\footnotetext{
${ }^{291}$ The same continue 'or a member of either House of Parliament or to enjoy any office or place of trust either civil or military or to have any grant of lands, tenements or hereditaments from the Crown to himself or to any other or others in trust for him...'. (spelling modernised) .These provisions are better dealt in a Parliament Act, a Government Act and legislation relating to the armed forces. The wording in italics is otiose since the royal demesne is now part of the Crown, not part of the sovereign's demesne as it was in 1700. See also Chitty (writing in 1820), $\mathrm{n}$ $13, \mathrm{p} 15$.

${ }^{292}$ See n 217 (second article), pp 41-2.

${ }^{293}$ See generally, M18.

${ }^{294}$ See $n 125$.

${ }^{295}$ This may not be necessary. It might quicker (and easier) to simply ask the Cinque Ports and the City of London to identify their charters and indicate any provisions they believe still exist.

${ }^{296}$ See M2, pp 548-51.
} 
- $\quad$ Waifs \& Estrays. Waifs comprise stolen goods cast away in flight. And, estrays comprise valuable animals of a tame (or reclaimable) nature found wandering in any manor (or lordship) of an unknown owner. ${ }^{297}$ Both are long obsolete and should be abolished.

In conclusion, a Crown Act should abolish the legal concepts of royal fish, waifs and strays.

\section{OBSOLETE CROWN LEGISLATION}

There is much legislation relating to the Crown - not to Parliament ${ }^{298}$ or to the Government ${ }^{299}$ - which is obsolete and which should be repealed. This comprises the following (a number of them have been referred to in prior sections of this article to which reference is made):

- $\quad$ The Statute concerning Tallage 1297, Confirmation of the Charters 1297, ch 6, Petition of Right 1627 (in part), Tenures Abolition Act $1660 \mathrm{~s} 4$ and the Free and Voluntary Present to his Majesty 1661, all refer to various feudal taxes once imposed by the sovereign (e.g. tallage (tasks, tax), aids, benevolences, prises, loans, forced loans, gifts) which taxes have long been obsolete. If the sovereign today sought to revive them without Parliament's consent, such would be illegal (see Bill of Rights 1688, s 1); (see 13).

- $\quad$ Prerogativa Regis c. 1324. In 1971, the sovereign confirmed that she no longer desired any prerogative in respect of whales and sturgeon. Further, the presumption of an implied reservation of an advowson is not required, since such is now a matter of interpretation of the relevant grant; (see 8(n) and 27).

- $\quad$ Revocation of the New Ordinances 1322. Ordinances were the older form of proclamation which were, generally, intended to be temporary. This Act revoked various ordinances (now obsolete) made by Edward II (1307-27) in 1311 who was later deposed. In 1969, the Law Commission recommended repeal of this Act. $^{300}$

- Status of Children Born Abroad 1350. This legislation was designed to clarify the common law position that the sovereign's children could inherit land in England, though they might be born abroad (see 4).

- Confirmation of the Charters 1297, ch 1, ${ }^{301}$ Confirmation of Liberties 1405-6, Confirmation of Charters and Statutes 1415-6 and Confirmation of Liberties 1423. The Act of 1423 repeats that of 1415 and it, in turn, repeats that of 1405. The Act of 1405 confirms Magna Carta - as does the Confirmation of the Charters 1297, ch 1. This was when there was uncertainty whether Magna Carta was part of the common law (and, thus, could be interpreted by the courts). These Acts, therefore, are obsolete and no longer needed, something the Law Commission considered to be the case in 1969. (see also 13). ${ }^{302}$

- Petition of Right 1627. This Act contains a petition relating to the Crown prerogatives of: (a) martial law; (b) billeting; (c) taxation. ${ }^{303}$ This Act is not needed (see 8(a) and 13).

- Crown Lands Act 1623. At common law, where the sovereign leased land and made it a condition of the lease that it was void for non-payment, the sovereign could re-enter, on default, without demand (though such did not apply to a grantee). This Act clarified that, where a tenant defaulted in payment of rent (or services) but remedied this prior to forfeiture of the lease, the sovereign (or any grantee) could not take advantage (i.e. re-enter without demand). This legislation is obsolete today. ${ }^{304}$

\footnotetext{
${ }^{297}$ See M5, pp 77-80.

${ }^{298}$ Legislation relating to Parliament should be consolidated in a Parliament Act. Further, legislation relating to the Crown Estate should be put in a Government Act (viz. Crown Lands Act 1823, Crown Lands Act 1851, Commissioners of Works Act 1852, Public Offices Fees Act 1879, Crown Lands Act 1894 (such seems obsolete), Commissioners of Works Act 1894, Crown Lands Act 1936, Crown Lands Act 1936, Crown Estate Act 1961).

${ }^{299}$ Legislation relating to the Government should be consolidated in a Government Act (viz. Ministers of the Crown Act 1975, Crown Agents Act 1979, Crown Agents Act 1995).

${ }^{300}$ See generally, $\mathbf{M} 7$.

${ }^{301}$ It states: 'Edward, by the grace of God, king of England, lord of Ireland, and duke of Guyan, to all those that these present letters shall hear or see, greeting. know ye that we, to the honour of God, and of holy church, and to the profit of our realm, have granted for us and our heirs, that the charter of liberties,.. which were made by common assent of all the realm, in the time of king Henry our father [i.e. Henry III], shall be kept in every point without breach. And we will that...our justices, sheriffs, mayors, and other ministers, which under us have the laws of our land to guide, shall allow the said charters pleaded before them in judgment in all their points; that is to wit, the Great Charter [i.e. Magna Carta] as the common law....'

${ }^{302}$ See generally, M7, p 18

${ }^{303}$ It states: 'and that your Majesty would be pleased to remove the said soldiers and mariners and that your people may not be so burdened in time to come. And that the aforesaid comissions for proceeding by martial law may be revoked and annulled. And that hereafter no commissions of like nature may issue forth to any person or persons whatsoever to be executed as aforesaid, lest by colour of them any of your Majesty's subjects be destroyed or put to death contrary to the laws and franchise of the land.' (spelling modernised)

${ }^{304}$ See M2, pp 554-6.
} 
- Convention Parliament Act 1688, Crown and Parliament Recognition Act 1689. The Act of 1688 simply confimed that the Parliament which sat after the abdication of James II (1685-9) (it was called the Convention Parliament) was a legitimate Parliament, despite no writs of summons being issued. It is, therefore, historic and spent. The Crown and Parliament Recognition Act 1689 confirmed that Acts passed by the Convention Parliament (in particular, the declaration of the same naming William and Mary as king and queen). It is also historic and spent. ${ }^{305}$

- $\quad$ Great Seal Act 1688, Great Seal (Offices) Act 1874, Great Seal Act 1884, Crown Office Act 1877, Crown Office Act 1890. These should be modernised (see 11).

- Coronation Oath Act 1688, Act of 6 Anne 1706, s 2. This laid down the statutory form of the coronation oath. However, this has changed over the centuries. If any religious content is removed, the Act of 6 Anne 1706, s 2 is no longer required. ${ }^{306}$ Nor, also, wording in the Act of Settlement 1700, s 3 or in the Union with Scotland Act 1706 and the Union with England Act 1707 (see 22(c)).

- $\quad$ Bill of Rights 1688. Much of the wording is now historic. In particular, it referred to the abdication of James II (1685-9) and the sovereigns becoming William and Mary (1688-1702). It also referred to the Crown passing (in the absence of children) to Queen Anne (which occurred). This wording is historic and it is unnecessary today since it is not doubted that the present sovereign is Elizabeth II (repeal of this legislation would not affect the prohibition on the sovereign being a catholic contained in the Bill of Rights 1688 , for which separate provision is required). For reference to taxation see $\mathbf{1 3 .}$

- $\quad$ Roval Mines Acts $1688 \& 1693$. The Crown prerogative should be abolished. Thus, these Acts are not required (see $\mathbf{8}(\mathbf{c})$.

- $\quad$ Act of Settlement 1700. This Act, s 1, dealt with the concern that Queen Anne (1702-14) would die without children (which she did). Thus, it provided for Hanoverian succession through Princess Sophia, her heirs and successors (which occurred, the Crown going to her grandson, George I). This is all historic and not necessary today since it is not doubted that the present sovereign is Elizabeth II, her heirs and successors (repeal of this legislation would not affect the prohibition on the sovereign being a catholic since this is contained in the Bill of Rights 1688, for which separate provision is required). As for the coronation oath, see the Coronation Oath Act 1688 above.

- Crown Lands Act 1702. Restricting the alienation of Crown lands to limited (31 year) leases (see s 5) is no longer required or commercially necessary. It has also been excepted in respect of most (if not all) Crown land. This Act, s 5, is obsolete. So too is s 7 (it restricted the alienation of certain Crown revenues, now obsolete). ${ }^{307}$

- Demise of the Crown Act 1702, Succession to the Crown Act 1707, Demise of the Crown Act 1727, Representation of the People Act 1867, s 51, Sheriffs Act 1887, s 3(3), Demise of the Crown Act 1901. These should be modernised, see 3 (demise).

- Sophia's Precedence Act 1711. This provided for precedence to be given before the Archbishop of Canterbury to the House of Hanover (i.e. Princess Sophia, her son (who later became George I) and the Duke of Cambridge (later, George II) as well as the 'heirs of the body' of Sophia, providing all were protestants. However, the House of Lords Act 1999 removed hereditary peers (bar 92). This Act is obsolete. ${ }^{308}$

- $\quad$ Statute of Westminster 1931 \& Roval Titles Act 1953. The 1931 Act bears a Preamble, paragraph 2.309 Almost certainly, this paragraph was never intended to have legal effect. Further, it no longer applies in relation to royal titles (which are now changed by the former dominions (i.e .Canada, Australia and New

\footnotetext{
${ }^{305}$ See M7, pp 16-8.

${ }^{306}$ It states; 'and after the demise of [HM] (whom God long preserve) the sovereign next succeeding to [HM] in the royal government of the kingdom of Great Britain and so for ever hereafter every king or queen succeeding and coming to the royal government of the kingdom of Great Britain at his or her coronation shall in the presence of all persons who shall be attending assisting or otherwise then and there present take and subscribe an oath to maintain and preserve inviolably the said settlement of the [CoE] and the doctrine worship discipline and government thereof as by law established within the kingdoms of England and Ireland the dominion of Wales and town of Berwick upon Tweed and the territories thereunto belonging.'

${ }^{307}$ See M 2. Also, Chitty, n 13, pp 203-4, 556-9.

${ }^{308}$ See M3, pp 109-11.

${ }^{309}$ It states: 'asmuch as the Crown is the symbol of the free association of the members of the British Commonwealth of Nations, and as they are united by a common allegiance to the Crown, it would be in accord with the established constitutional position of all the members of the Commonwealth in relation to one another that any alteration in the law touching the succession to the throne or the royal style and titles shall hereafter require the assent as well of the parliaments of all the dominions as of the parliament of the [UK].' (emphasis supplied)
} 
Zealand) and the British Overseas Territories without common consent). Thus, it should be repealed. The remainder of this Act should be placed in a Parliament Act. The content of the 1953 Act should be placed in a Crown Act.

- Accession Declaration Act 1910. This is connected to the coronation oath. Indeed, it repeats it in any case. It is not required.

- $\quad$ Titles Deprivation Act 1917, His Majesty's Declaration of Abdication Act 1936. These Acts are now spent.

- $\quad$ Regency Acts 1937, 1943 and 1945. This should be placed in a Crown Act, see 3.

- $\quad$ Treasure Trove Act 1996, ss 1 \& 4. Abolishing the Crown prerogative (and any franchise) to treasure trove will not affect its right to the same under this Act (which was intended to supercede it), see 8(d).

\section{OBSOLETE COURTS}

There are a number of obsolete common law (i.e. Crown established) courts which have not sat, in some cases, for more than 100 years. ${ }^{310}$ They should be abolished. It may be noted that some - like the Court of Claims - are not 'courts' as such. Rather, they employ the old use of the term, meaning an assembly.

\section{OTHER CROWN PREROGATIVES}

This article has discussed many Crown prerogatives. Those suitable for a Crown Act. However, there remain other Crown prerogatives. ${ }^{311}$ These would be better inserted in a:

- Parliament Act; or

- Government Act; or

- Other legislation,

since they directly relate to the same. These are as follows:

\section{(a) Parliament}

Speech
Election
Arrest \& Imprisonment
Assent to Legislation
Sitting of Parliament
Appointments
Citizenship
War
Peace

Freedom of speech, debates and Parliamentary proceedings

Freedom of election of MPs

Freedom from arrest and imprisonment inside Parliament

Crown assent to Parliamentary legislation

i.e. summons, meeting, sitting, prorogation, adjournment, fixed term

Prime Minister, Ministers, Privy Councillors

MPs to be British citizens

Prerogative to declare war

Prerogative to declare peace

There are, also, more minor prerogatives which are likely obsolete, viz. the Crown prerogative to:

- $\quad$ approve the election of the Speaker of the House of Commons (' $H C$ ');

- $\quad$ confirm the privileges of the HC;

- $\quad$ prorogue Parliament in person (or by order of lords commissioners appointed under the great seal);

- dissolve Parliament in person;

- $\quad$ appoint the Clerk of the Parliaments; ${ }^{312}$

- $\quad$ fine (amerce) a member of the HC (or the House of Lords) for non-attendance at Parliament subsequent to a summons.

\footnotetext{
${ }^{310}$ See generally, GS McBain, Modernisng the English Court System (2013) Journal of Politics and Law, vol 6, no 3, pp 17-44.

311 These are dealt with in a report by the Ministry of Justice, The Governance of Britain. Review of the Executive Royal Prerogative Powers: Final Report. (October 2009). See also House of Commons Public Administration Select Committee, Taming the Prerogative: Strengthening Ministerial Accountability to Parliament. Fourth Report of Session 2003-4(2004).

${ }^{312}$ See Clerk of the Parliaments Act, s 2.
} 


\section{(b) $\underline{\text { Military }}$}

Armed Forces
Armed Forces - Overseas
Angary
National Emergency
War - Enemy Alien
Enemy - Trading
Export

Control, organisation and disposition of the armed forces (including the commissioning of officers, pay, pensions and the royal navy); ${ }^{313}$

Deployment and use of the armed forces overseas for military purposes (i.e. armed conflicts) which fall short of war;

Taking neutral property on UK territory or enemy territory ${ }^{314}$

Military power in the case of national emergency; 315

In wartime, to intern, expel (deport) or otherwise control an enemy alien;

Trading with the enemy;

Export of weapons and ammunition, contraband of war.

These should be placed in an Armed Forces Act.

\section{(c) Government - Foreign}
Treaties
Make and ratify treaties;
Passports
Issue, refuse, impound and revoke passports;
Territory
Acquire (inc. by way of annexation) and cede territory;
Diplomacy
Conduct diplomacy;
Ambassadors \& Commissioners
Send and receive ambassadors and high commissioners;
Foreign States
Recognize foreign states;
British Overseas Territories
Govern BOT;
Channel Island, Isle of Man
Responsibity for the Channel Islands and the Isle of Man;
Diplomatic Protection
Accord diplomatic protection to British citizens abroad.

These relate to the operation of government and they should be placed in a Government Act.

\section{(d) Government - Domestic}

Civil Service

Public Appoimtments

Crown Estate

Postage Stamps

Adoption

Public Inquiries

HM Stationary

Crown Immunity

Seas, Rivers

Pirates
Government of the civil service;

Appoint persons to public offices; ${ }^{316}$

Administer the Crown Estate; ${ }^{317}$

Permit (and administer) pre-paid postage stamps;

Issue certificates of eligibility to prospective inter-country adopters; ${ }^{318}$

Hold public inquiries (inc. royal commissions);

Appoint the controller of HM's Stationary Office;

The immunity of the Crown in various situations;

Prerogative to the seabed (and river beds). Also, to fishing;

Goods seized may be detained by the Crown.

These relate to the operation of government and they should be placed in a Government Act.

\section{(e) Legal}
Judges
Where the appointment is not otherwise statutory

\footnotetext{
${ }^{313}$ The army and the air force are maintained by legislation. So should the navy.

${ }^{314}$ Walker, n 249(angary) 'The modern right of angary is the right of belligerents to destroy or take up and use in case of absolute necessity, for the purpose of offence or defence, neutral property on their territory or on enemy territory. There can be no requisition on the open sea. It is usually justified as an exercise of the power of a sovereign state. It does not extend to compelling neutral individuals to render services. There is a duty to pay compensation for damage done. It is comparable to the power of states to requisition property of their own nationals, or to seize enemy property on their territory.'

315 This includes military support given to the police and civil authorities.

${ }^{316}$ This is other than the appointment of the PM and Ministers of the Crown.

317 This includes the ownership of the foreshore, narrow seas and public navigable rivers.

318 This refers to non-Hague Convention cases.
} 


$\begin{array}{ll}\text { Queens' Counsel } & \text { Prerogative to appoint } \\ \text { Attorney-General } & \text { Office and role } \\ \text { Solicitor General } & \text { Office and role } \\ \text { Mercy } & \text { Prerogative to exercise mercy (and reprive) } \\ \text { Insolvency/Bankruptcy } & \text { Legal rights of priority of the Crown }\end{array}$

The first two should be placed in a Courts Act. The second three relate to the operation of government and should be placed in a Government Act. The last should be placed in insolvency (bankruptcy) legislation.

\section{CONCLUSION}

It seems widely accepted that something should be done to modernise the Crown prerogatives and legislation relating to the Crown.

- Maitland pointed this out more than a 100 years ago. So has the House of Commons more recently. It is also, manifestly, obvious that many (indeed, very many) Crown prerogatives are obsolete and they should be abolished;

- It also seems obvious that any Crown prerogatives still required should be placed in legislation. This is not only to modernise them. It, also, reflects the fact that the role of the sovereign is now a formal one only. More importantly, it confirms that all Crown authority and functions are - and should be - subject to the control, and oversight, of Parliament.

Would any of this be difficult? One would suggest not. A draft Crown Act is attached in Appendix D. Finally, it is noted that some of the content of such will involve political decisions (e.g. whether the duchy of Lancaster should be abolished). This is a matter for politicians. The draft simply sets out the position at its highest, and to cover the field, and leaves others to decide.

\section{$\underline{\text { Appendix A - Constitutional Legislation }}$}

Date

\section{$\underline{\text { Legislation applying to Parliament }}$}

Bearing of Armour Act

Summons to Parliament

Privilege of Parliament Act

House of Lords Precedence Act

Privilege of Parliament Act

Crown and Parliament Recognition Act

Meeting of Parliament

Parliamentary Privilege Act

Parliamentary Privilege Act

Acts of Parliament (Commencement) Act

Meeting of Parliament Act

Meeting of Parliament Act

House of Commons (Disqualification) Act

Crown Debts Act

Acts of Parliament (Expiration) Act

Clerk of the Parliaments Act

Parliamentary Papers Act

Deputy Speaker Act

House of Commons Offices Act

Parliamentary Witnesses Act

Parliamentary Oaths Act

Prorogation Act

Parliamentary Returns Act

Meeting of Parliament Act

Parliamentary Witnesses Oaths Act

Short Titles Act

Parliament Act

Chequers Estate Act

Parliament (Qualification of Women) Act

Royal and Parliamentary Titles Act

Parliament (Elections and Meeting) Act

Laying of Documents before Parliament (Interpretation) Act

Parliament Act

Chequers Estate Act

Acts of Parliament Numbering and Citation Acts

Parliamentary Commissioner Act

House of Commons Disqualification Act

Parliamentary and other Pensions and Salaries Act

House of Commons (Administration) Act 


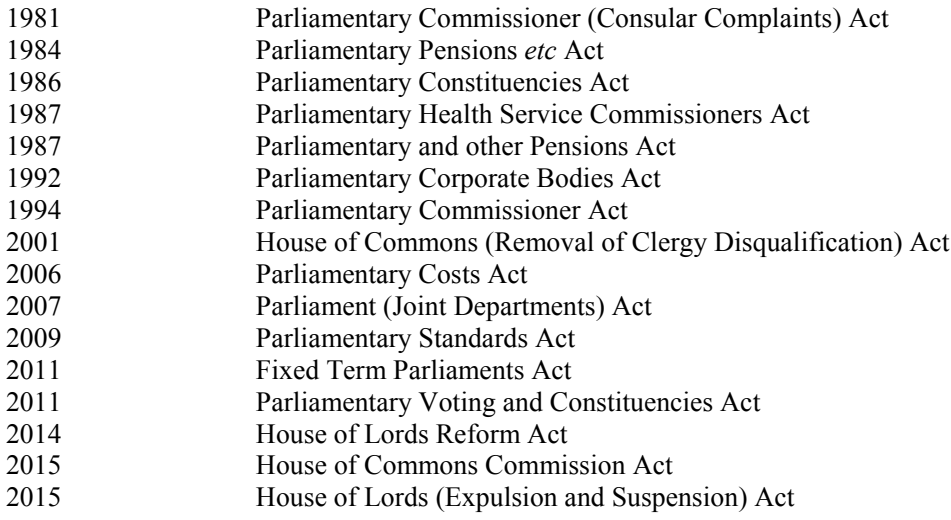

\section{Legislation applying to the Crown}

Confirmation of the Charters*

Statute concerning Tallage *

Magna Carta

Prerogativa Regis (temp incert, possibly 1272-3, may also be 1324) *

Revocatio Novarum Ordinationum *

Status of Children Born Abroad*

Liberties, Charters and Statutes Confirmed *

Confirmation of Charters and Statutes *

Confirmation of Liberties *

Crown Lands Act*

Petition of Right *

Tenures Abolition Act * 319

Free and Voluntary Present to HM *

Convention Parliament *

Royal Mines Act*

Bill of Rights ${ }^{320}$

Great Seal Act *

Coronation Oath Act*

Royal Mines Act*

Act of Settlement ${ }^{321}$

Crown Lands Act*

Demise of the Crown Act *

Union with Scotland Act

Succession to the Crown Act*

Union with Scotland (Amendment) Act

Princess Sophia's Precedence Act*

Demise of the Crown Act *

Crown Private Estate Act*

Union with Ireland Act

Crown Lands Act

Roman Catholic Relief Act *

Civil List Act*

Crown Lands Act **

Commissioners of Works Act **

Privy Council Registrar Act (place in a Courts Act)

Durham County Palatine Act*

Clerk of the Council Act *

Crown Private Estates Act *

Representation of the People Act *

Crown Private Estates Act *

Great Seal (Offices) Act*

Crown Office Act *

Public Offices Fees Act **

Great Seal Act *

Crown Office Act * (spent)

Crown Lands Act ** (may be spent)

Commissioners of Works Act **

Demise of the Crown Act*

Osborne Estate Act *

Accession Declaration Act *

Titles Deprivation Act (spent)*

\footnotetext{
${ }^{319}$ Section 8 (guardianship, modernised, should be in a Crown Act)

${ }^{320}$ A Crown Act would repeal s 2 and most of the introduction and s 1 .

${ }^{321}$ A Crown Act would repeal ss 1, 2 and part of $s 3$.
} 


$\begin{array}{ll}1920 & \text { Duchy of Lancaster Act * } \\ 1925 & \text { Honours (Prevention of Abuses) Act * } \\ 1931 & \text { Statute of Westminster (place in a Parliament Act) } \\ 1936 & \text { Crown Lands Act ** } \\ 1936 & \text { HM's Declaration of Abdication Act (spent) * } \\ 1953 & \text { Royal Titles Act * } \\ 1961 & \text { Crown Estate Act ** } \\ 1963 & \text { Peerage Act* } \\ 1975 & \text { Ministers of the Crown Act ** } \\ 1979 & \text { Crown Agents Act ** } \\ 1988 & \text { Duchy of Lancaster Act * } \\ 1995 & \text { Crown Agents Act ** } \\ 2010 & \text { Constitutional Reform and Government Act } \\ 2011 & \text { Sovereign Grant Act * } \\ 2013 & \text { Succession to the Crown Act * }\end{array}$

Note. A Crown Act (see Appendix D) would seek to repeal with the Acts marked with an *. Those marked with an ** are better reserved to a Government Act.

\section{$\underline{\text { Appendix B - Texts on English Constitutional Law }}{ }^{322}$}

This list seeks to list texts on English constitutional law. However, it excludes texts relating to the following:

- Coronations; ${ }^{323}$

- Duchies of Cornwall and Lancaster; ${ }^{324}$

- $\quad$ City of London and Cinque Ports; ${ }^{325}$

- $\quad$ Royal Household; ${ }^{326}$

- $\quad$ Spiritual and temporal power, ${ }^{327}$

- Parliament; ${ }^{328}$ - $\quad$ Readings, essays, thoughts, observations, inquiries and considerations dealing with individual aspects of constitutional law;

- Crown Estate;

- Minor student texts.

\section{Texts prior to 1567}

Prior to Staunford's Exposition of the King's Prerogative in 1567 there was little written on English constitutional law - especially on the powers (prerogatives) of the Crown. This was generally due to the subject being a matter of 'arcana imperii' [secrets of the empire/realm] and often dangerous for subjects to express opinions on. Before 1567, English constitutional law was mentioned in the following:

- $\quad$ H Bracton (trans Thorne), On the Law and Customs of England c. 1240 (Cambridge UP, 1968-76, 4 vols) (also online); ${ }^{330}$

- $\quad$ Britton (c. 1290). Translation with notes by FM Nichols (John Byrne, 1901) (also online); ${ }^{.31}$

- $\quad$ Fleta(c. 1290). Selden Society reports ('SS') (also online); ${ }^{332}$

- J Fortescue (Sir), Governance of England (c. 1471-6, ed Plummer, 1885);33

\footnotetext{
${ }^{322}$ A detailed list of texts and treatises on constitutional law may be found in Sweet \& Maxwell, A Legal Bibliography of the British Commonwealth of Nations ( $2^{\text {nd }}$ ed, 1955), 2 Vols. This covers English law from 1189 - 1955.

${ }^{323}$ See Sweet \& Maxwell, n 322, vol 1, pp 121-2.

${ }^{324}$ See texts cited in GS McBain, Time to Abolish the Duchy of Lancaster (2013) Rev. of European Studies, vol 5, no 4, pp 172-93 and GS McBain, Time to Abolish the Duchy of Cornwall ? (2013) Rev. of European Studies, vol 5, no 5, pp 40-58.

${ }^{325}$ See texts cited in GS McBain, Liberties and Customs of the City of London - Are there any Left? (2013) Int. Law Research, vol 2, no 1, 3295 and GS McBain, The Charters of the Cinque Ports - Are they Still Needed? (2013) Rev. of European Studies, vol 5, no 2, pp 90-126.

${ }^{326}$ See Sweet \& Maxwell, n 322, vol 1, pp 122-4. See also vol 2.

${ }^{327}$ Ibid, pp 124-7. See also vol 2.

${ }^{328}$ Ibid, pp 127-140. For House of Lords, see pp 140-6, for the House of Commons, see pp 146-9. For Bills, see pp 153-4. See also vol 2.

${ }^{329}$ Ibid, pp 358-66 (up to1800) and vol 2 (up to 1955).

${ }^{330}$ See bracton.law.harvard.edu/

${ }^{331}$ See www.anglo-norman.net/

${ }^{332}$ SS, vols 72, 89 \& 99. See also www.wshein.com/. See also the Mirror of Justices (c. 1290), SS, vol 7.

${ }^{333}$ For the best modern edition see Cambridge Texts in the History of Political Thought ed S Lockwood (1997).
} 
- $\quad$ R Constable, Prerogativa Regis Tertia Lectura (1495, ed. SE Thorne, 1949). ${ }^{334}$

As for cases, these tend to be found in the following:

- $\quad$ Selden Society Reports (vols 1-128)(see SS website); ${ }^{.335}$

- $\quad$ Yearbooks (1268-1535)(see website of David Seipp); ${ }^{336}$

- $\quad$ Rolls of Parliament (1275-1504)(Rotuli Parliamentorum, also on CD and online), ${ }^{337}$

- $\quad$ English Reports (online, see Sweet \& Maxwell website. Also that of Butterworths);

- $\quad$ Abridgments. Those of Statham (c .1490) ${ }^{338}$ and Fitzherbert (c. 1516); 339

\section{Legal Texts $1567-1700$}

References to cases may be found in the abridgments of:

- $\quad$ A Fitzherbert, La Graunde Abridgment (Tottell, $3^{\text {rd }}$ ed 1577); $3^{340}$

- $\quad$ R Brooke, La Graunde Abridgment (Tottell, 1586); ${ }^{341}$

- H Rolle, Abridgment des plusieurs Cases et Resolutions del Common Ley (A Crooke et al, 1668, 2 vols);

- $\quad$ W Hughes, Grand Abridgment of the Law (Henry Twyford et al, 1660-3, 3 vols); ${ }^{342}$

- W Sheppard, Grand Abridgment of the Common and Statute Law of England ( $1^{\text {st }} \mathrm{ed} 1675,3$ vols).

For texts, see:

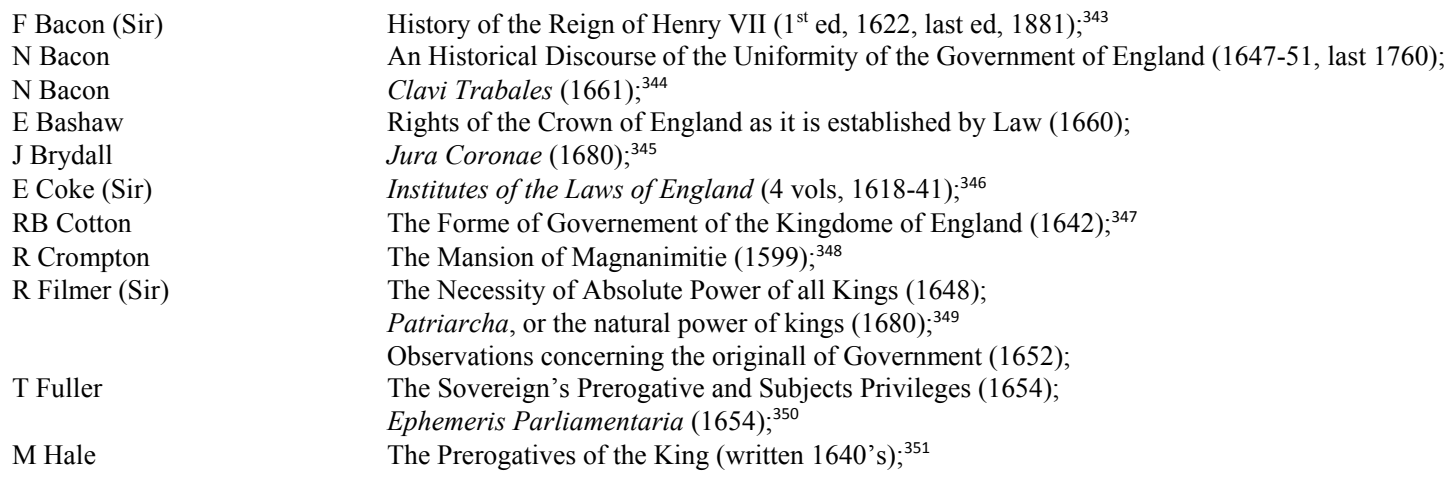

\footnotetext{
${ }^{334}$ See also Selden Society, vol 113 (readings of Thomas Frowyk and John Spelman on Prerogativa Regis in 1495 and 1521 respectively).

${ }^{335}$ See selden.society.com. Also, www.wshein.com/ which has put SS vols 1-99 online.

${ }^{336}$ The best hardcopy edition is that of Maynard (Vulgate, 1678), reprinted by LBE. David Seipp (a professor at Boston university) has put translations of most of the 22,000 Yearbook cases online in the form of an Index. See www.bu.edu/law/faculty/scholarship/yearbooks).

${ }^{337}$ See www.sd-editions.com

${ }^{338}$ N Statham, Abridgment of the Law (Pynson, c 1490). See translation of MC Klingelsmith, Boston Book Co. 1915.

${ }^{339}$ A Fitzherbert, La Graunde Abridgment.The $3^{\text {rd }}$ ed (1577) is generally preferred.

${ }^{340}$ Reprinted by LBE.

${ }^{341}$ Ibid.

${ }^{342}$ Ibid.

${ }^{343}$ For a modern edition, see that of Hesperus Press (ed B Thompson, 2007).

${ }^{344}$ 'Or Nailes fastened by some great masters of assemblyes confirming the king's supremacy, the subjects duty, church government by bishops.'

345 'His Majesties Royal Rights and Prerogatives asserted against Papal usurpations and all other anti-monarchical attempts and practices.' (1680).

${ }^{346}$ Coke makes remarks on constitutional matters in the course of his writings. For a modern edition of Coke see that of 1824 (5 vols), republished by the LBE.

347 'Wherein is manifested the customary uses of the kings of England upon all occasions, either of marriage, peace or warre, to call their peeres and barons of the realme to be bartners [sic] in treatizes, and to give their juditious advice.'

348 'Wherein is shewed the acts of sundry English kings etc in defence of their country etc. Whereunto is also adjoined a collection of diverse laws and statutes etc with a briefe table shewing what munition ought to be kept by all sorts of her majestie's subjects for the defence of her realms.'

${ }^{349}$ Cf. A Sidney, Discourses concerning Government (pub 1698) and J Tyrrell, Patriarcha non Monarcha (1681).

350 'Or a faithful register of the transactions in Parliament in the third and fourth years of the reign of our late sovereign lord king charles.'

${ }^{351}$ Sir Matthew Hale's Prerogatives of the King, DEC Yale (ed), Selden Society, vol 92 (1976).
} 


\begin{tabular}{|c|c|}
\hline B Lane & Prerogatives of the Monarchs of Great Britain (1684); \\
\hline W Mantell & Short Treatise on the Laws of England (1644); $3^{352}$ \\
\hline J Sadler & Rights of the Kingdom (1682); ${ }^{353}$ \\
\hline T Smith & De Republica Anglorum (written 1562-5, 1583); ${ }^{354}$ \\
\hline W Staunford (Sir) & Exposition of the King's Prerogative ( $1^{\text {st }}$ ed 1567 , last ed 1607$) ;{ }^{355}$ \\
\hline J Tyrrell & Bibliotheca Politica or Enquiry into the ancient Constitution of England (1691, last ed, 1718); \\
\hline R Twysden (Sir) & Certaine Considerations upon the Government of England (ed JM Kemble)(1849). ${ }^{356}$ \\
\hline
\end{tabular}

\section{Legal Texts: $1700-1800$}

References to cases may be found in the abridgments of:

- W Nelson, Abridgment of the Common Law (E \& R Gosling, 1725-6, 3 vols);

- $\quad$ M Bacon, New Abridgment of the Law (the best ed is that of H Gwillim (ed), $5^{\text {th }}$ ed, 7 vols, 1798);

- $\quad$ E Viner, A General Abridgment of the Law and Equity (GCJ \& J Robinson, $1^{\text {st }}$ ed, 1742-53, $2^{\text {nd }}$ ed 1791); $;^{357}$

- J Comyns, Digest of the Laws of England ( $1^{\text {st }}$ ed, 1765, 5 vols plus supplement, last ed, 1822);

- J Lilley, Practical Register ( $2^{\text {nd }}$ edn, 1765, 2 vols).

For texts, see:

R Acherley
AA Anglesey
W Blackstone
T Brecknock
T Cunningham
T Gurdon
J Hargrave
J Hatsell
D Hume
G Jacob
M Hale
TC Paget
W Petty
W Petyt
FP Plowden
Somers (Lord)
E Wynne

Britannic Constitution or Fundamental Form of Government in Britain (1741); 358 The Privileges of the House of Lords and Commons Argued (1702); ${ }^{359}$ Commentaries on the Laws of England (Clarendon Press, $1^{\text {st }}$ ed, 1765-9, Univ. of Chicago Press rep 1979);

Droit le Roy (1764); ${ }^{360}$

Introduction to the Knowledge of the Laws and Constitution of England (1763); The History of the High Court of Parliament (1731, 2 vols); Collectanea Juridica (1791, 2 vols); ${ }^{361}$

Precedents of Proceedings in the House of Commons (1796, vol 4); ${ }^{362}$ The History of England (1754-62);

Lex Constitutionis ( $1^{\text {st }}$ ed 1719 , last ed, 1737) ${ }^{363}$

The Jurisdiction of the Lords House or Parliament (1796);

Some Reflections on the Administration of Government (1740);

On the Constitution and Laws of England (1701);

Jus Parliamentarium ( $2^{\text {nd }}$ ed, 1741, 2 parts);

Jura Anglorum, the Right of Englishmen (1792);

Judgment of whole Kingdoms and Nations ${ }^{364}\left(1^{\text {st }}\right.$ ed $1710,12^{\text {th }}$ ed (last), 1774);

Eunomus or Dialogus concerning the Law and Constitution of England ( $1^{\text {st }}$ ed 1767 , last ed, 1822).

Useful historical collections of this period are:

Parliamentary or Constitutional History from the Earliest Times to the Restoration of Charles II (1762, 24 vols);

J Rushworth

Somers (Lord)

Historical Collections of Private Passages of State (1703-8); 365

Collection of Scarce and Valuable Tracts chiefly relating to the Constitution of these

352 'With the jurisdiction of the High Court of Parliament. With the Liberties and Freedomes of the Subjects.'

353 'or Customs of our Ancestours touching the duty, power, election or succession of our kings and Parliaments, freely discussed through the British, Saxon, Norman Laws and Histories'. (Locke recommended it as a treatise in which was to be found the ancient constitution of the government of England).

354 'The Maner of Government, or Policie of the Realme of England'. The best modern edition is that edited by Mary Dewar (CUP, 1982).

355 'Exposition of the Kinges Prerogative collected out of the great Abridgment of Fitzherbert, and other olde writers of the lawes of England; with the process to the same prerogative appertaining.'

${ }^{356}$ See Camden Society, vol 45.

$3571^{\text {st }}$ ed reprinted by LBE (23 vols) with CD (with wordsearch).

${ }^{358}$ With supplement, 'Reasons for Uniformity in the State.'

${ }^{359}$ In two Conferences between both houses, April $19^{\text {th }}$ and $22^{\text {nd }} 1671$.

360 'Or a digest of the rights and prerogatives of the Imperial Crown of Great Britain.'

361 'Consisting of tracts relative to the law and constitution of England.'

${ }^{362}$ Relates to conferences and impeachment.

${ }^{363 ،}$ 'or, Gentleman's Law, being a complete treatise of all the laws and statutes relating to the king, and prerogative of the Crown, Nobility, Houses of Lords and Commons etc, with the manner of passing bills in both Houses.'

${ }^{364}$ The full title is 'Judgment of whole Kingdoms and Nations concerning the Rights, Power and Prerogative of Kings and the Rights, Privleges and Properties of the People.'

${ }^{365}$ 'Historical Collections of Private Passages of State, Weighty Matters in Law, Remarkable Proceedings in Five Parliaments $1618-48\left(1^{\mathrm{st}} \mathrm{ed}\right.$ 1659 , last ed 8 vols, 1721). 


\section{Legal Texts: $1800-50$}

$\mathrm{J}$ Allen

TC Anstey

J Bentham

W Bentham

G Bowyer

J Chitty (Jun)

ES Creasy

JJ De Lolme

JJ De Lolme

W Enfield

G Goldsmith

H Hargrave

CW/GW Johnson

E Marshall

JJ Park

FP Plowden

W Ritchie

Russell (Earl)

E Taylor

TG Western

\section{Legal Texts: $1850-75$}

Amos

RC Austin

W Bagehot

G Brodie

H Broom

Brougham (Lord)

G Chalmers

ES Creasy

AC Ewald

W Forsyth C

EA Freeman

H Hallam

TE May

\section{Legal Texts: $1875-1900$}

A Amos

W Anson

AV Dicey

F Fulton

FA Inderwick,

J Johnston

J Macy

FC Montague

LO Pike

C Ransome

JH Round

W Stubbs

TP Taswell-Langmead

HO Wakeman

HO Wakeman \& A Hassall
Inquiry into the Rise and Growth of the Royal Prerogative in England (1849);

Guide to the History of the Law and Constitutions of England (1845);

Plea for the Constitution (1803);

Origin and History of the Constitution of England (1834);

The English Constitution (1841);

A Treatise on the Law of the Prerogatives of the Crown (1820);

Textbook of the Constitution: Magna Carta, Petition of Right, Bill of Rights (1848);

Constitution and Laws of England ( $1^{\text {st }}$ ed 1772 , last ed, $14^{\text {th }}$ ed, 1834);

Rise and Progress of the English Constitution (1838);

Compendium of the Laws and Constitution of England (1809);

Laws and Constitution of England (1816);

Jurisconsult Exercitations (1811, 3 vols);

British Constitution: Its Origin and History (1835);

Treatise on the British Constitution (1812);

The Dogmas of the Constitution (1832);

Constitution of the United Kingdom of Great Britain and Ireland (1802);

Essays on Constitutional Law and the Forms of Process (1824);

An Essay on the History of the English Government and Constitution ( $2^{\text {nd }}$ ed, 1823);

Book of Rights (1833); ${ }^{366}$

Commentaries on the Constitution and Laws of England ( $1^{\text {st }}$ ed $1838,3^{\text {rd }}$ ed, 1841).

The English Constitution in the Reign of Charles II (1857);

Plea for the Constitution ( $2^{\text {nd }}$ ed, 1859);

The English Constitution ( $1^{\text {st }}$ ed, 1867);

Constitutional History of the British Empire from the Accession of Charles I to the Restoration (1866);

Constitutional Law viewed in relation to Criminal law $\left(1^{\text {st }} \mathrm{ed}, 1866,2^{\text {nd }}\right.$ ed, 1885$)$;

The British Constitution: its History, Structure and Working (1st ed, 1861);

Opinions of Eminent Lawyers on Various Points of English Jurisprudence (1814);

The Rise and Progress of the English Constitution (1st ed, 1853, last ed, 17 $\left.7^{\text {th }} \mathrm{ed}, 1907\right)$;

Our Constitution (1867);

Cases and Opinions on Constitutional Law (1869);

The Growth of the English Constitution from the Earliest Times $\left(1^{\text {st }}\right.$ ed $1872,3^{\text {rd }}$ ed, 1876);

Constitutional History of England (1485-1870) ( $1^{\text {st }}$ ed 1827, last ed 1876-72);

The Constitutional History of England since the Accession of George the Third, 1760-1860

( $1^{\text {st }}$ ed 1861-3, last ed, 1912, 2 vols).

Fifty Years of the English Constitution 1830 -1880 (1880);

The Law and Custom of the Constitution( $1^{\text {st }}$ ed, $1886,5^{\text {th }}$ ed 1922,3 vols $) ;^{367}$

Introduction to the Study of the Law of the Constitution $\left(1^{\text {st }}\right.$ ed, 1885, 10th ed, 1961);

Manual of Constitutional History (1875);

The Interregnum (1891);

British Constitution (1899);

The English Constitution. A Commentary on its Nature and Growth (1897);

Elements of English Constitutional History $\left(1^{\text {st }}\right.$ ed $1897,3^{\text {rd }}$ ed 1936);

A Constitutional History of the House of Lords (1894);

Rise of Constitutional Government in England (1883);

Geoffrey de Mandeville. A Study of the Anarchy (1892);

Constitutional History of England in its Origin and Development (to 1485$)\left(1^{\text {st }}\right.$ ed 1880 , last ed 1951);

English Constitutional History ( $1^{\text {st }}$ ed 1875 , last ed, $\left.10^{\text {th }}, 1946\right) ;^{368}$

English Constitutional History ( $1^{\text {st }}$ ed $1887,2^{\text {nd }}$ ed 1891 );

Essays Introductory to the Study of English Constitutional History (1896).

\section{Legal Texts: $1900-1919$}

GB Adams

JF Baldwin

D Chalmers/ C Asquith

JC Davies
The Origin and Growth of the English Constitution ( $1^{\text {st }}$ ed 1912, $2^{\text {nd }}$ ed, 1920);

The King's Council in England during the Middle Ages (1913);

Constitutional and Administrative Law ( $\left(1^{\text {st }}\right.$ ed 1910, $5^{\text {th }}$ ed, 1936);

Baronial Opposition to Edward III (1918);

\footnotetext{
366 'or Constitutional Acts and Parliamentary proceedings affecting Civil and Religious liberty in England, from Magna Carta to the present time, historically arranged.'

${ }^{367}$ Vol 1 (Parliament), $5^{\text {th }}$ ed 1922, vol 2 (Crown, in 2 parts), $4^{\text {th }}$ ed, 1935.

${ }^{368}$ See also AM Wilshere, Analysis of Taswell-Langmead's Constitutional History (1 ${ }^{\text {st }}$ ed 1902, last ed 1929).
} 
H St C Feilden

EM Fordham

AB Keith

F Kern

WWLucas

CH McIlwain

WS McKechnie

FW Maitland

FG Marcham

WA Morris

FH Relf

EW Ridges

\section{Legal Texts: 1919-30}

GB Adams

DO Dykes

DO Dykes/JR Phillips

L Ehrlich

CS Emden

E Jenks

AB Keith

M Macdonagh

WA Morris

C Petit-Dutaillis

K Pickthorn

AF Pollard

JH (Sir) Ramsay

JR Tanner

AB White

\section{Legal Texts: $1930-1940$}

M Amos

D Chalmers/OH Phillips

SB Chrimes

CS Emden

HRG Greaves

RH Gretton

JA Hawgood

WI Jennings

WI Jennings

EA Jolliffe

DL Keir

AB Keith

AB Keith

WPM Kennedy

HJ Laski

HJ Laski

D Ogg

MA Thomson

RF Treharne

ECS Wade/GG Phillips
JH (Sir) Ramsay

A Short Constitutional History of England (1911, $2^{\text {nd }}$ rev 1887);

Evolution of Local and Imperial Government from the Teutonic Conquest to the Present Day (1904);

The Theory of State Succession (1907);

Kingship and Law in the Middle Ages (1914, trans SB Chrimes);

The Corporate Nature of English Sovereignty (1911);

The High Court of Parliament (1910);

Magna Carta (1914)

Constitutional History of England (1st ed, 1908);

Constitutional History of Modern England 1485 to the Present (1908);

The English Government at Work 1327-1366 (1940);

Dawn of the Constitution [1216-1307] (1908);

The Petition of Right (1917);

Constitutional Law of England ( $1^{\text {st }} \mathrm{d} 1905,8$ th ed,1950).

Constitutional History of England ( $1^{\text {st }}$ ed, $1921,2^{\text {nd }}$ ed 1935);

Sourcebook of Constitutional History from 1660 (1930);

Chapters in Constitutional Law (1930);

Proceedings against the Crown (1216-1377)(1921);

Principles of British Constitutional Law (1925);

The State and the Nation (1919);

Constitution, Administration and Laws of the Empire (1924);

The English King. The Monarchy and Royal Family, Historical, Constitutional and

Social(1929);

Constitutional History of England to 1216 (1930);

Studies and Notes Supplementary to Stubbs Constitutional History (trans 1930);

Some Historical Principles of the Constitution (1925);

The Evolution of Parliament ( $1^{\text {st }}$ ed 1920, 2nd ed, 1926);

Dawn of the Constitution [1216-1307] (1908);

English Constitutional Conflicts of the $17^{\text {th }}$ Century 1603-1689 (1928);

The Making of the English Constitution 449-1485 (1926).

The English Constitution (Longmans, 1930);

Constitutional Law of England ( $1^{\text {st }}$ ed 1936, $2^{\text {nd }}$ ed 1945);

English Constitutional Ideas in the Fifteenth Century (1937);

The People and the Constitution (1933);

The British Constitution ( $1^{\text {st }}$ ed 1938, $3^{\text {rd }}$ ed 1955);

The King's Majesty (1930);

Modern Constitutions since 1787 (1939);

The Law and the Constitution $\left(1^{\text {st }}\right.$ ed $1933,3^{\text {rd }}$ ed, 1959);

Cabinet Government ( $1^{\text {st }}$ ed 1936, last ed, 1969);

The Constitutional History of Medieval England to $1485\left(1^{\text {st }}\right.$ ed $1937,4^{\text {th }}$ ed,1961);

The Constitutional History of Modern Britain from 1485 ( $1^{\text {st }}$ ed 1938 , last, $\left.9^{\text {th }}, 1969\right)$;

Introduction to the British Constitutional Law (1931);

The King and the Imperial Crown (Longmans, 1936);

Essays in Constitutional Law (1934);

The State in Theory and Practice (1935);

Parliamentary Government in England (1938);

Constitutional History (1934);

A Constitutional History of England 1642-1801 (1938, vol 4);

The Baronial Plan of Reform 1258-1263 (1933);

Constitutional Law $\left(1^{\text {st }}\right.$ ed $1931,14^{\text {th }}$ ed 2007)..$^{369}$

\section{Legal Texts: $1940-1950$}

LS Amery
E Barker
SB Chrimes
RC Fitzgerald
WI Jennings
AB Keith
HJ Laski
M Knappen
JF Willard
GL Williams
B Wilkinson

Thoughts on the Constitution ( $1^{\text {st }}$ ed $1947,2^{\text {nd }}$ ed 1953);

Essays on Government (1945);

English Constitutional History $\left(1^{\text {st }}\right.$ ed $1948,4^{\text {th }}$ ed, 1967$) ;{ }^{370}$

Some Aspects of the British Constitution (1944);

The British Constitution ( $1^{\text {st }}$ ed 1941, 5th ed, 1968);

The Constitution of England from Queen Victoria to George VI (1940);

Reflections on the Constitution (1951);

Constitutional and Legal History of England (1942);

The English Government at Work 1327-37 (1940-50, 3 vols);

Crown Proceedings (1948);

Constitutional History of England 1216-1399 (1948-52, 2 vols).

\footnotetext{
${ }^{369}$ Became AW Bradley \& KD Ewing, Constitutional and Administrative Law.

${ }^{370}$ See also SB Chrimes, English Constitutional History: A Select Bibliography (1958).
} 


\section{Legal Texts: $1950-1970$}

J Borrie

SB Chrimes

JW Gough

RFV Heuston

JC Holt

RS Hoyt

WI Jennings

JDB Mitchell

GT Lapsley

HJ Laski

CR Lovell

JDB Marshall

OH Phillips

C Roberts

B Schwartz

JR Tanner

HWR Wade/CF Forsyth

KC Wheare

B Wilkinson

DCM Yardley
Elements of Public Law (1967);

Introduction to the Administrative History of Medieval England (1952);

Fundamental Law in English Constitutional History (1955);

Essays in Constitutional Law ( $1^{\text {st }}$ ed 1961, 2nd ed, 1964);

Magna Carta (1965);

The Royal Demesne in English Constitutional History 1066-1272 (1950, rep 1963);

The Queen's Government (1955);

Constitutional Law ( $1^{\text {st }}$ ed 1964, 2nd ed, 1968);

Crown, Community and Parliament in the Later Middle Ages (1951);

Reflections on the Constitution (1951);

English Constitutional and Legal History (1962);

Some Problems of the Constitution ( $1^{\text {st }}$ ed $1959,4^{\text {th }}$ ed 1967);

Constitutional Law (1952); ${ }^{37}$

The Growth of Responsible Government in Stuart England (1966);

Roots of Freedom: A Constitutional History of England (1967);

English Constitutional Conflicts of the Seventeenth Century 1603-1689 (1962);

Administrative Law ( $1^{\text {st }}$ ed $1961,9^{\text {th }}$ ed 2004);

Modern Constitutions ( $1^{\text {st }}$ ed 1951, $2^{\text {nd }}$ ed 1966);

Studies in the Constitutional History of the Thirteenth and Fourteenth Centuries (1952);

Introduction to British Constitutional Law ( $1^{\text {st }}$ ed $1960,7^{\text {th }}$ ed 1990).

\section{Legal Texts: $1970-1990$}

J Alder

R Brazier

R Brazier

JAG Griffith

I Harden \& N Lewis

C Harlow

TC Hartley \& JAG Griffith

J Harvey \& L Bather The Britis

J Jowell/D Oliver

G Marshall

G Marshall

JGA Pocock

GO Sayles

I Stevens

H Street \& R Brazier

B Tierney

C Turpin \& A Tomkins

HWR Wade
Constitutional and Administrative Law (1 ${ }^{\text {st }}$ ed 1989, 9th ed, 2013);

Constitutional Texts (1990);

Constitutional Practice ( $1^{\text {st }} \mathrm{d}$ 1988, 2nd ed, 1994);

Parliament Functions, Practice and Procedures (1989);

Noble Lie: The British Constitution and the Rule of Law (1986);

Public Law and Politics (1986);

Government and Law $\left(1^{\text {st }}\right.$ ed $1975,2^{\text {nd }}$ ed 1981$) ;{ }^{372}$

Constitution and Politics ( $1^{\text {st }}$ ed $1963,5^{\text {th }}$ ed 1982);

The Changing Constitution ( $1^{\text {st }}$ ed $1985,7^{\text {th }}$ ed 2011$)$;

Constitutional Theory (1971);

Constitutional Conventions (1984);

Ancient Constitution and the Feudal Law (1 ${ }^{\text {st }}$ ed 1957; rep 1987);

The King's Parliament of England (1975);

Constitutional and Administrative Law (1982);

Constitutional and Administrative Law ( $5^{\text {th }}$ ed, 1985);

Religion, Law and the Growth of Constitutional Thought 1150-1650 (1982);

British Government and Constitution ( $1^{\text {st }}$ ed 1985, $7^{\text {th }}$ ed 2012);

Constitutional Fundamentals (1980, Hamlyn Lectures).

\section{Legal Texts: $1990-2000$}

TRS Allan

E Barendt

H Barnett

R Blackburn

R Blackburn/RPlant

V Bogdanor

R Brazier

D Butteret al

A Carroll

SA De Smith/R Brazier

H Elsyng

H Fenwick/G Phillipson

H Fenwick/ G Phillipson

M Foley

R Hazell

A Le Sueur et al

I Loveland

S Millins/N Whitty

CR Munro

D Oliver

D Oliver
Law, Liberty and Justice, Legal Foundations of British Constitutionalism (1993); An Introduction to Constitutional Law (1998);

Constitutional and Administrative Law ( $1^{\text {st }}$ ed 1995, 10th ed, 2013);

Constitutional Studies (1992);

Constitutional Reform (1999); ${ }^{373}$

The Monarchy and the Constitution $\left(1^{\text {st }}\right.$ ed, 1995$)$

Constitutional Reform ( $1^{\text {st }}$ ed 1991, $3^{\text {rd }}$ ed 2008);

The Law, Politics and the Constitution (1998);

Constitutional and Administrative Law ( $1^{\text {st }}$ ed $1998,5^{\text {th }}$ ed 2009);

Constitutional and Administrative Law ( $1^{\text {st }}$ ed 1971; 8th ed, 1998);

Judicature in Parlement (1991);

Sourcebook on Public Law (1997);

Text, Cases and Materials on Public Law and Human Rights ( $1^{\text {st }}$ ed $\left.1995,3^{\text {rd }}, 2011\right)$;

The Politics of the British Constitution (1999);

Constitutional Futures (1999);

Public Law (1 ${ }^{\text {st }}$ ed, 1997, 2nd ed, 2013);

Constitutional Law, Administrative Law and Human Rights ( $1^{\text {st }}$ ed 1996, 374

$6^{\text {th }}$ ed 2012);

Feminist Perspectives on Public Law (1999);

Studies in Constitutional Law ( $1^{\text {st }}$ ed, 1987, 2nd ed, 1999);

Government in the UK (1991);

Constitutional Reform in the UK (2003);

\footnotetext{
${ }^{371}$ The text is based on Chalmers and Phillips. It became OH Phillips \& Jackson.

372 'An Introduction to the Working of the Constitution of Britain.'

373 'The Labour Government's Constitutional Reform Agenda.'

374، Constitutional Law: A Critical Introduction'.
} 
N Parpworth et al

D Pollard et al

M Sunkin/S Payne (eds)

B Thompson

C Vincenzi
Constitutional and Administrative Law $\left(1^{\text {st }}\right.$ ed 1997, $7^{\text {th }}$ ed, 2012);

Constitutional and Administrative Law ( $1^{\text {st }}$ ed $1990,4^{\text {th }}$ ed, 2007);

The Nature of the Crown: A Legal and Political Analysis ( $1^{\text {st }}$ ed, 1999)

Textbook on Constitutional and Administrative Law ( $1^{\text {st }}$ ed 1982, $2^{\text {nd }}$ ed 1993);

Crown Powers. Subjects and Citizens (1998).

\section{Legal Texts: 2000-12}

V Bogdanor
M Elliott/R Thomas
E Giussani
O Gross/ FN Aolain
R Hazell
R Hazell/R Rawlings
A King
P Leyland
A Lyon
M Ryan
A Tomkins
L Webley/H Samuels
CA Whatley
E Wicks

V Bogdanor

E Giussani

O Gross/ FN Aolain

R Hazell/R Rawlings

A King

M Rya

L Webley/H Samuels

E Wicks
The New British Constitution (2009);

Public Law (2011);

Constitutional and Administrative Law ( $1^{\text {st }}$ ed, 2008);

Law in Times of Crisis (2006);

Constitutional Futures Revisted ( $1^{\text {st }}$ ed 2008, $2^{\text {nd }}$ ed 2010);

Devolution, Law Making and the Constitution (2005);

The British Constitution (2007);

The Constitution of the United Kingdom ( $1^{\text {st }}$ ed 2007, $2^{\text {nd }}$ ed, 2012);

Constitutional History of the UK (2003);

Unlocking Constitutional and Administrative Law ( $1^{\text {st }}$ ed 2007, $2^{\text {nd }}$ ed 2010);

Public Law (2003);

Public Law ( $1^{\text {st }}$ ed 2009, $2^{\text {nd }}$ ed 2012);

The Scots and the Union (2006);

The Evolution of a Constitution (2006).

\section{Documents on Constitutional History}

- $\quad$ GB Adams \& WM Stephens, Select Documents of English Constitutional History (1901);

- $\quad$ F Bowen, Documents of the Constitution of England and America from Magna Carta to 1789 (1854)

- $\quad$ WC Costin \& JS Watson, Law and Working of the Constitution. Documents 1660-1914 (1 ${ }^{\text {st }}$ ed,1952);

- $\quad$ WC Costin \& JS Watson, Law and Working of the Constitution. Documents 1660-1783 (1 $\left.1^{\mathrm{st}} \mathrm{ed}, 1952\right)$;

- $\quad$ DO Dykes, Source Book of Constitutional History from 1660 (1930);

- $\quad$ SR Gardiner, The Constitutional Documents of the Puritan Revolution 1625-1660 (3 ${ }^{\text {rd }}$ ed, 1906);

- $\quad$ HJ Hanham, The Nineteenth Century Constitution: 1815-1914 (1969);

- $\quad$ EC Lodge \& GA Thornton, English Constitutional Documents 1307-1485 (1935);

- $\quad$ DJ Medley, Original Illustrations of English Constitutional History 1307-1485 (1 ${ }^{\text {st }}$ ed 1910, $2^{\text {nd }}$ ed 1926);

- $\quad$ AF Pollard, Reign of Henry VIII from Comtemporary Sources (1914); ${ }^{375}$

- GW Prothero, Select Statutes and other Constitutional Documents illustrative of the Reigns of Elizabeth I and James I. (1 ${ }^{\text {st }}$ ed $1894,4^{\text {th }}$ ed 1913);

- $\quad$ CGR Robertson, Select Statutes, Cases and Documents to illustrate English Constitutional History 1660-1832 (1 ${ }^{\text {st }}$ ed 1904, last 1949);

- C Stephenson \& FG Marcham, Sources of English Constitutional History (1972);

- $\quad$ W Stubbs, Select Charters and other Illustrations of English Constitutional History $\left(1^{\text {st }}\right.$ ed 1870, last, 9 $\left.{ }^{\text {th }}, 1913\right)$;

- $\quad$ JR Tanner, Tudor Constitutional Documents 1485-1603 (1 $1^{\text {st }} 1930,2^{\text {nd }}$ ed 1951);

- JR Tanner, Constitutional Documents of the Reign of James I 1603-1625 (1 $1^{\text {st }}$ ed 1930, $2^{\text {nd }}$ ed 1950).

\section{APPENDIX D - DRAFT CROWN ACT}

An Act to modernise various matters relating to the Crown.

\section{Contents}

\section{The Sovereign}

1. The Sovereign

2. Succession

\section{Crown Prerogatives}

3. Crown Prerogatives

4. Legal Presumptions

5. Legal Restrictions

6. Franchise of a Crown Prerogative

7. Immunity

8. Arrest

9. Crown Jewels, Royal Palaces, Royal Collections, Osborne Estate

10. Counties Palatine

11. Tenurial Services

12. Great Seal

${ }^{375}$ See vol 2, pt 1, Constitutional Documents. 


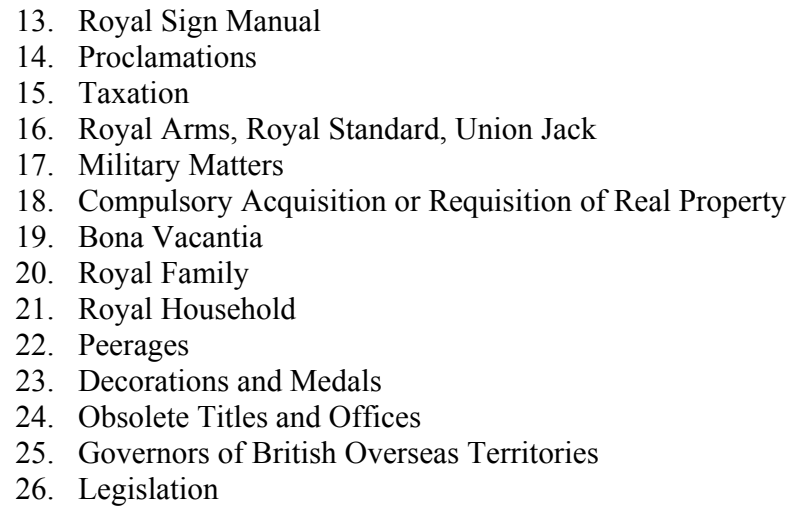

\section{Church of England and the Crown}

27. Head of the Church of England

28. Church of England Clerics

29. Patronage

30. Coronation Declaration

31. Religion of the Sovereign

Duchies of Cornwall and Lancaster

32. Duchy of Cornwall

33. Inheritance

34. Management

35. Mines and Foreshore

36. Taxation

37. Abolition of the Duchy of Lancaster

\section{Privy Council}

38. Membership

39. Absence of Clerk of the Council

\section{Charters}

40. City of London and Cinque Ports Charters

41. County, Borough and Town Charters

42. Crown Charters

\section{Other}

43. Private Estate of the Sovereign

44. Guardianship of Minors

\section{General}

45. Repeals and Cancellation

46. Abolition

47. Obsolete Courts

48. Interpretation

49. Application

\section{$\underline{\text { Schedules }}$}

1. Regency

2. Civil List

3. Abolished Prerogatives

4. Royal Palaces and Royal Collections

5. Royal Household

6. Decorations and Medals

7. Obsolete Titles and Offices

8. Coronation Declaration

9. Duchy of Cornwall - Manors and Rivers 
10. Duchy of Cornwall - Management Acts

11. Duchy of Cornwall - Mines

12. Privy Council Declaration

13. Cancelled City of London and Cinque Ports Charters

14. Repealed Crown Legislation

15. Repealed Church of England related Legislation

16. Repealed Duchy of Cornwall Legislation

17. Cancelled Duchy of Cornwall Charters

18. Abolished Duchy of Cornwall Rights

19. Repealed Duchy of Lancaster Legislation

20. Abolished Obsolete Courts

21. Disclaimer of a Hereditary Peerage

22. Private Estate of the Sovereign

Note. All references to the 'sovereign' refer to the sovereign in person (i.e in the body personal) and all references to the 'Crown' refer to sovereign in person as well as to the same in the body politic.

\section{The Sovereign}

\section{The Sovereign}

(1) Person. The sovereign is Queen Elizabeth II and the heirs of her body.

(2) Style and Title. The sovereign, for use in relation to the UK (and all other the territories for whose foreign relations the Government in the UK is responsible):

(a) may adopt such style and titles as she may think fit and

(b) issue, for that purpose, a proclamation under the Great Seal. ${ }^{376}$

(3) Demise. The demise of the sovereign shall not result in the dissolution of Parliament. However, Parliament shall meet immediately, if prorogued or adjourned at the time. Nor shall it result in the termination of any:

(a) Crown office in the UK or elsewhere;

(b) office or appointment relating to the principality of Wales or the duchies of Lancaster ${ }^{377}$ and Cornwall;

(c) membership of the privy council;

(d) claims (or legal proceedings) by, or against, the Crown;

(e) use of the Great Seal or any other public seal, all of which shall continue to be used as the seals of the successor until the same shall order to the contrary.

(4) Regency. A regency shall take effect in accordance with Schedule 1.

(5) Legal Nature. The sovereign is a corporation sole.

(6) Body Politic. The Crown, when it refers to the sovereign in the body politic, is never in abeyance or suspended (that is, the sovereign, in the body politic, never dies).

(7) Property. The sovereign may own property (real and personal), to which the general law shall apply. ${ }^{378}$

(8) UK Law. The laws of the $\mathrm{UK}^{379}$ are the birthright of the people thereof and the sovereign must act in accordance with the same.

(9) Funding. A civil list shall take effect in accordance with Schedule 2.

\section{Succession}

(1) In determining succession to the Crown the:

(a) gender of a person born after 28 October 2011 does not give that person (or that person's descendants) precedence over any other person (whenever born);

(b) fact that a child of the sovereign (whether born before, or after, the sovereign becomes such) was born outside the UK is immaterial.

(2) A person who (when the person marries) is one of the 6 persons next in the line of succession to the Crown must obtain the consent of the sovereign before marrying. Where such consent has been obtained, it must be:

\footnotetext{
${ }^{376}$ Alternatively, it may be better to provide 'A SI shall, from time to time, set out the style and title of the sovereign, for use in relation to the UK (and all other the territories for whose foreign relations the Government in the UK is responsible'.

${ }^{377}$ This Crown Act anticipates the abolition of this duchy.

${ }^{378}$ This is subject to any matter retained in Schedule 22.

${ }^{379}$ The Act of Settlement 1700 refers to the laws of England.
} 
(a) signified under the Great Seal;

(b) declared in the Privy Council; and

(c) recorded in the books of the Privy Council.

(3) The effect of a person's failure to comply with (2) is that the person (and the person's descendants) from the marriage are disqualified from succeeding to the Crown.

\section{Crown Prerogatives}

\section{Crown Prerogatives}

(1) The prerogatives (and any franchise thereof) in Schedule 3 are abolished, as described.

(2) The following are abolished, any Crown prerogative accorded to:
(a) a consort of the sovereign;
(b) the heir(ess) apparent to the throne (and any consort of the same);
(c) a queen dowager;
(d) a princess royal;
(e) any member of the Royal Family, except the sovereign.

\section{Legal Presumptions}

(1) The following are abolished, any legal presumption that the:

(a) sovereign cannot be a minor;

(b) Crown cannot be negligent (in the case of the sovereign, s 7(1)(a) shall apply).

(2) The Crown shall not have laches (delay) attributed to it.

\section{Legal Restrictions}

(1) The following are abolished, any legal restriction on the:
(a) sovereign being a trustee;
(b) sovereign being an executor;
(c) Crown being a joint tenant, or a tenant in common, with a person;
(d) Crown reserving (that is, alienating) rent.

(2) The sovereign:
(a) shall not give evidence in a court of law in her own cause
(b) may not act as a minister of the Crown;
(c) may not hold a Crown office;
(d) may not attend, or sit in, Cabinet;
(e) cannot alter succession to the Crown in her will.

(3) The restriction in (2)(a) shall not prevent the sovereign giving written evidence to a UK court in a civil case between subjects.

\section{Franchise of a Crown Prerogative}

(1) The Crown may not franchise, inter alia, its right to:
(a) summon, dissolve or prorogue Parliament
(b) assent to any Act of Parliament;
(c) appoint any judge;
(d) issue a pardon;
(e) naturalise a person

\section{Immunity}

(1) The sovereign has:

(a) civil immunity; save where the common law remedies of: (i) petition of right; or (ii) suit against the AttorneyGeneral, apply;

(b) criminal immunity, save where a sentence of life imprisonment may be imposed.

\section{Arrest}

(1) The sovereign cannot:
(a) be arrested; or
(b) arrest a person. 
(2) Any Crown prerogative preventing the arrest of a person in a Royal Palace is abolished.

\section{Crown Jewels, Royal Palaces and Royal Collections}

(1) The following are owned by the nation (that is, they are held by the sovereign in the body politic), the:
(a) Crown Jewels;
(b) Royal Palaces as listed in Schedule 4, Part A;
(c) Royal Collections, as listed in Schedule 4, Part B;
(d) Osborne House, as described in Schedule 4, Part C.

\section{Counties Palatine}

(1) The following are abolished, the
(a) county palatine of Chester and the title Earl of Chester;
(b) county palatine of Durham;
(c) county palatine of Lancaster;
(d) office of Attorney-General of the county palatine of Durham;
(e) office of Solicitor-General of the county palatine of Durham.

\section{Tenurial Services}

(1) The following tenurial services and obligations to the Crown, and to any other person, are abolished:

\section{Great Seal}

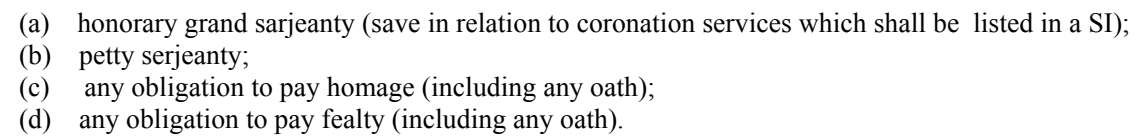

(1) Any common law requirement respecting the use of the Great Seal is abolished.

(2) The Great Seal shall be used:
(a) to seal treaties with foreign rulers and States;
(b) to seal all public acts, instruments and orders of State that concern the whole UK;
(c) for a grant by the Crown of a title of honour;
(d) for a grant by the Crown of a franchise;
(e) where legislation specifies.

(3) A warrant under the sovereign's royal sign manual:
(a) countersigned by the Lord Chancellor; or by

(b) a principal secretary of state,

shall be a necessary and sufficient authority for passing any instrument under the Great Seal, according to the tenor of such warrant.

(4) The Lord Chancellor may from time to time make, revoke and vary, regulations respecting the:
(a) passing of instruments under the Great Seal;
(b) warrants for that purpose; and
(c) the preparation of such instruments and warrants.

(5) Warrants shall be prepared by the Clerk of the Crown in Chancery (whose appointment and fees such regulations may also provide for).

(6) A Committee of the Privy Council (comprising the Lord Chancellor, [Lord Privy Seal $]^{380}$ and a principal secretary of state, acting in case of difference according to the opinion of any two of them) may from time to time:

(a) direct impressions with the same device as the Great Seal be taken in such manner and of such size(s) as they may from time to time prescribe, on embossed paper, wax, wafer, or any other material. Any such impressions (hereafter, called a 'Wafer Great Seal') shall be in the same custody as the seals of which they are impressions. When attached to (or embossed on) any document required to be usually authenticated by (or passed under) the Great Seal, it shall confer on that document the same validity in all respects as if the document itself had been authenticated by, or passed under, the Great Seal;

(b) by order, make, revoke, add to, or alter rules prescribing the documents to which the Wafer Great Seal are to be attached.

\footnotetext{
${ }^{380}$ This is now a sinecure. Thus, reference to the same is, probably, not needed.
} 
(7) It shall not be necessary to the validity of any document to (or on which) a Wafer Great Seal is attached (or embossed) to prove that the attachment (or embossing) of such wafer seal was authorised and no evidence to the contrary shall be received;

(8) Any rule purporting to be made pursuant to (6)(b) shall be laid before both Houses of Parliament.

\section{Roval Sign Manual}

(1) Execution by the sovereign under the royal sign manual is valid on the subscription of the sovereign's signature save where legislation requires otherwise.

\section{Proclamations}

(1) Any Crown prerogative to make, and issue, a proclamation is abolished save where such is:
(a) authorized by legislation;
(b) to summon or prorogue Parliament. ${ }^{381}$

(2) The sovereign may issue factual announcements (which are not required to be made under the Great Seal) in the case of:

(a) a Royal Event;

(b) the grant of (or a change in) a title of honour or dignity.

\section{Taxation}

(1) Any Crown prerogative to levy:

(a) any form of tax or toll; or

(b) the same for a longer time (or otherwise as permitted by legislation),

without the consent of Parliament, is abolished.

(2) The sovereign (including in right of the duchy of Lancaster) shall pay income tax.

\section{Royal Arms, Royal Standard and Union Jack}

(1) The royal arms (ensigns armorial) of the UK shall be quarterly. The first and fourth quarters shall be the arms of England, the second quarter shall be the arms of Scotland and the third quarter shall be the arms of Northern Ireland. The Crown may licence the use of the royal arms;

(2) The royal standard is the personal flag of the sovereign. It may only be flown with the licence of the same;

(3) Save for (2), the union flag (the Union Jack) shall be used in all the sovereign's flags, banners, standards and ensigns. It shall be azure with the crosses saltire of St Andrew and St Patrick quarterly per saltire and countercharged argent and gules. The latter shall be fimbriated of the second quarter (surmounted by the cross of St George) and of the third quarter, fimbriated as to the saltire.

\section{Military Matters}

(1) The sovereign shall be, ex officio, ceremonial commander-in-chief of the armed forces. Save as aforesaid, no other person shall hold a ceremonial rank in the armed forces, including any member of the Royal Family.

(2) Any Crown prerogative to impose an:

(a) embargo; or

(b) a blockade on civilian shipping,

is abolished. The Crown may only impose the same with the consent of Parliament.

(3) Parliament may authorize the Crown:

(a) in time of war or other emergency

(b) to requisition any British or BOT registered ship

(c) on payment of reasonable compensation.

Any Crown prerogative to do so is hereby abolished.

(4) Any Crown prerogative in respect of prize and bounty (booty) is abolished. Title to any enemy Military Equipment captured in wartime shall, on capture, forthwith pass to the MOD and it may be:

(a) destroyed

${ }^{381}$ It is intended that a Parliament Act deal with this matter. 
(b) scrapped;

(c) disabled; or

(d) otherwise dealt with by the MOD,

without payment of compensation.

\section{Compulsory Acquisition or Requisition of Real Property}

(1) Any Crown prerogative to compulsorily acquire (or requisition):

(a) any real property in the UK (or in any BOT)

(b) in peace time or in war time,

is abolished.

(2) During war time, the Crown may compulsorily acquire (or requisition) any real property in a Foreign Country occupied by the enemy, without the payment of compensation, where such real property is:

(a) occupied by the enemy; or

(b) likely to be occupied by the enemy.

\section{Bona Vacantia}

(1) Any Crown prerogative to bona vacantia (as well as any franchise of the same) is abolished and title to any bona vacantia shall pass to, and be administered by, HM Treasury.

\section{Royal Family}

(1) The title 'His (or her) Royal Highness' ('HRH') is restricted to members of the Royal Family;

(2) The control of the sovereign over the education (and custody) of children who are minors is restricted to those of the Royal Family.

\section{Royal Household}

(1) The royal household comprises the senior officials, their offices and titles referred to in Schedule 5, Part A.

(2) The offices and titles in (1) shall be modernised to refer to those in Schedule 5, Part B.

(3) The following are abolished, the:

(a) honorary posts and offices referred to in Schedule 5, Part C

\section{$\underline{\text { 22. Peerages }}$}

(b) Royal Almonry.

(1) The Crown prerogative to create any new:
(a) hereditary; or
(b) life

peerage, is abolished, save that (b) shall not apply in the case of any judge appointed to the Supreme Court or to the Senior Courts, as defined in the Senior Courts Act 1981.

(2) A hereditary peerage may be disclaimed in accordance with Schedule 21.

(3) The sovereign shall have power by letters patent to confer on any person a peerage for life which shall, during the life of the person on whom it is conferred, entitle the same to:

(a) rank as a baron under such style as may be appointed by the letters patent;

(b) receive writs of summons to attend the House of Lords and sit and vote therein accordingly,

and shall expire on his death

(4) The High Court shall have jurisdiction to hear any peerage claim in place of the House of Lords.

\section{Decorations and Medals}

(1) The decoration and medals awarded by the Crown shall comprise those referred to in Schedule 8, Part A.

(2) The decorations and medals in:

(a) Schedule 6, Part B shall be placed in abeyance [or are abolished];

(b) Schedule 6, Part C are abolished, excepting present holders. 
(3) Any decoration and medals awarded by the Crown in (1) and (2)(a) may be abolished by means of a SI, save for the following, the
(a) Victoria Cross;
(b) George Cross;
(c) Elizabeth Cross.

\section{Obsolete Titles and Offices}

(1) The titles and offices in Schedule 7, are abolished.

(2) Any legislation, or common law matter:
(a) attendant on; or
(b) consequential to (1),

may be repealed (or amended) by a SI

\section{Governors of British Overseas Territories}

(1) The following powers may be delegated, by a SI, to a governor of a BOT if required; the power to:

\section{Legislation}
(a) assent to legislation;
(b) pardon, or reprieve, a person

(1) The Crown (including the sovereign in person) is not bound by legislation unless referred to expressly or by implication.

(2) Reference to the sovereign in person in legislation includes her successors.

\section{Church of England and the Crown}

\section{Head of the Church of England}

(1) The Archbishop of Canterbury shall be head of the CoE in place of the sovereign

\section{$\underline{\text { 28. Church of England Clerics }}$}

(1) The appointment of (as well as any resignation of, or notification of the dismissal of) any:

(a) archbishop shall be made by the General Synod;

(b) bishop shall be made by the Archbishop of Canterbury;

(c) other person to any ecclesiastical office shall be made by the diocesan bishop, save where a Measure provides otherwise.

\section{Patronage}

(1) The legal proceeding of jus patronatus is abolished.

(2) Any:

(a) advowson (whether donative, elective, collative, presentative or otherwise);

(b) power of presentation;

(c) power to appoint a person to an ecclesiastical office;

(d) power of visitation; or

(e) other power of patronage (including being patron paramount),

held by the Crown (including in any royal or other peculiar) in respect of the CoE shall, herewith, pass to the diocesan bishop of the diocese where the same is held. A SI shall list the powers transferred and to whom.

\section{Coronation Declaration}

(1) The sovereign, in the presence of the people assembled at the sovereign's coronation, shall audibly give (or sign) the declaration in Schedule 8 which shall be administered by the:
(a) Archbishop of Canterbury; or
(b) Archbishop of York; or
(c) any other bishop of the realm the sovereign shall appoint.

\section{Religion of the Sovereign}

(1) The religion of the sovereign is a private matter for the sovereign.

\section{Duchies of Cornwall and Lancaster}




\section{Duchy of Cornwall}

(1) Nature. The duchy is an estate comprising the manors (and the bed of certain rivers) referred to in Schedule 9 as well as other land and property.

(2) Ownership. The duchy is owned by the nation (that is, held by the sovereign in her body politic) in which the Duke has a life interest.

(3) Inalienable. The duchy, and the title 'Duke of Cornwall', are inalienable.

(4) Legal Nature of the Duke. The Duke is a corporation sole.

\section{Inheritance}

(1) Eldest Child of the Sovereign. Subject to (2) and (3), the duchy shall automatically pass: (a) on the birth of the eldest son (or daughter) of the body of the sovereign, to the same; or (b) to the eldest son (or daughter) of the body of the sovereign, when the sovereign becomes such.

(2) Eldest Child Dies. If the eldest child in (1) dies without issue, the duchy shall automatically pass to the second son or daughter of the body of the sovereign, as if the same were the eldest. However, if the eldest child in (1) dies leaving issue, the duchy shall revert to the sovereign.

(3) No Children. Until the sovereign has children, the sovereign shall hold the duchy.

\section{Management}

(1) The duchy shall be managed according to the provisions of Schedule $\mathbf{1 0}$ [or a SI].

\section{Mines and Foreshore}

(1) The general law on mines and mining shall apply in the duchy (including those manors called assessionable manors)[save for Schedule 11].

(2) Any local customs in respect of mines and mining in the duchy (including tin bounding, whether in Cornwall or elsewhere) are abolished.

(3) [Any foreshore in the duchy held by the Duke shall be transferred to the Crown.]

\section{Taxation}

(1) The Duke of Cornwall (including in right of the duchy of Cornwall) shall pay income tax.

\section{Abolition of the Duchy of Lancaster}

(1) The duchy of Lancaster, and the title Duke of Lancaster, are abolished, including any right to:

(a) any jura regalia;

(b) bona vacantia;

(c) escheat;

(d) exercise patronage in respect of the CoE, including any advowson;

(e) appoint a high sheriff;

(f) appoint a lord lieutenant. ${ }^{382}$

(2) All real and personal property and all rights and obligations in respect of (1) are hereby transferred to the Crown Estate, the details of which shall be set out in a SI.

\section{Privy Council}

\section{Membership}

(1) To be a member of the privy councillor, a person:

(a) must be a British citizen;

(b) shall sign the declaration in Schedule 12

\section{Absence of Clerk of the Council}

(1) Whenever the sovereign, with the advice of the Privy Council, makes provision for the performance of the duties of the clerk of the Council in the event of his absence any person acting under the authority of the Order in Council on his behalf shall: in relation to:

382 This Act seeks to abolish these matters. Therefore, they need not be expressly referred to. 
(a) the signing, certifying, and issuing of Orders of Her Majesty in Council; or

(b) the Orders of the lords and others of the Privy Council, under any Acts of Parliament; or

(c) any other duties of that office,

have and perform all the powers and functions, and be in the place of, the clerk of the said Council. ${ }^{383}$

\section{$\underline{\text { Charters }}$}

\section{City of London and Cinque Ports}

(1) The charters from the Crown to the City of London (the 'City') and to the Cinque Ports, referred to in Schedule 13, are cancelled.

(2) A SI may:

(a) amend the dates of the charters in Schedule 13, if required;

(b) add new charters to Schedule 13 if: (i) a report prepared by a legal expert indicates the same are obsolete; or (ii) they comprise charters of inspeximus (confirmation) only.

(3) Any obligation of the mayor of the City to pay homage or fealty to the Crown is abolished and The City of London (Various Powers) Act 1959, s 5(1) is amended to state 'The Corporation of London shall continue to have the right to elect a mayor annually who shall be elected by the liverymen of the City of London assembled in Common Hall in the manner laid down in an Act of Common Council.'

\section{County, Borough and Town Charters}

(1) A SI may cancel all, or part, of any charter granted by the Crown to a county, borough or a town if a report prepared by the Law Commission (or a legal expert appointed by the Government) indicates the same is obsolete or spent.

\section{Crown Charters}

(1) All counties, boroughs, towns, bodies corporate or other persons (legal or individual) shall, on request, supply details of any Crown charter granted to them, to:

(a) the Law Commission; or

(b) a legal expert appointed by the Government

(2) A SI may cancel all, or part, of any charter referred to in (1) if a report prepared by the Law Commission (or a legal expert appointed by the Government) indicates that the same is obsolete or spent.

\section{Private Estate of the Sovereign}

(1) Any private estate of the sovereign shall be subject to the provisions of Schedule 22, Part A.

(2) The legislation in Schedule 22, Part B is repealed.

\section{Guardianship of Minors}

(1) A dying father (or mother) may, in a document intended to have legal effect (including a will);

(a) nominate a person to exercise the care and education of

(b) any child (or children) of his under the age of 16

(c) up to that age

and any nomination shall be upheld save where the:

(d) mother (father) of (b) wishes to undertake the same; or

(e) a Family Court determines otherwise. ${ }^{384}$

\section{Repeals \& Cancellation}

(1) Crown Legislation. The legislation in Schedule 14 is repealed, as described.

(2) Church of England related Legislation. The legislation in Schedule $\mathbf{1 5}$ is repealed, as described.

(3) Duchy of Cornwall Legislation. The legislation in Schedule $\mathbf{1 6}$ is repealed, as described.

(4) Duchy of Cornwall Charters. The charters in Schedule 17 are cancelled, as described.

(5) Duchy of Cornwall Rights. The rights of the duchy (or duke) in Schedule 18 are abolished.

${ }^{383}$ This re-states the Clerk of the Council Act 1853, as modernised.

${ }^{384}$ This section (which modernises that in the Tenures Abolition Act 1660) could be inserted in family legislation dealing with guardianship. 
(6) Duchy of Lancaster Legislation. The legislation in Schedule 19 is repealed.

(7) Any legislation or common law matter or charter attendant on, or consequential to (1)-(6) may be repealed (or amended) by a SI.

\section{Abolition}

(1) The following obsolete legal concepts are abolished:
(a) royal fish;
(b) waif (being goods thrown away by a thief in flight);
(c) estrays (being certain stray animals found in manors whose owner is unknown).

\section{Obsolete Courts}

(1) The obsolete courts in Schedule 20 are abolished and their jurisdiction shall be transferred pursuant to an SI.

\section{Interpretation}

(1) In this Act:

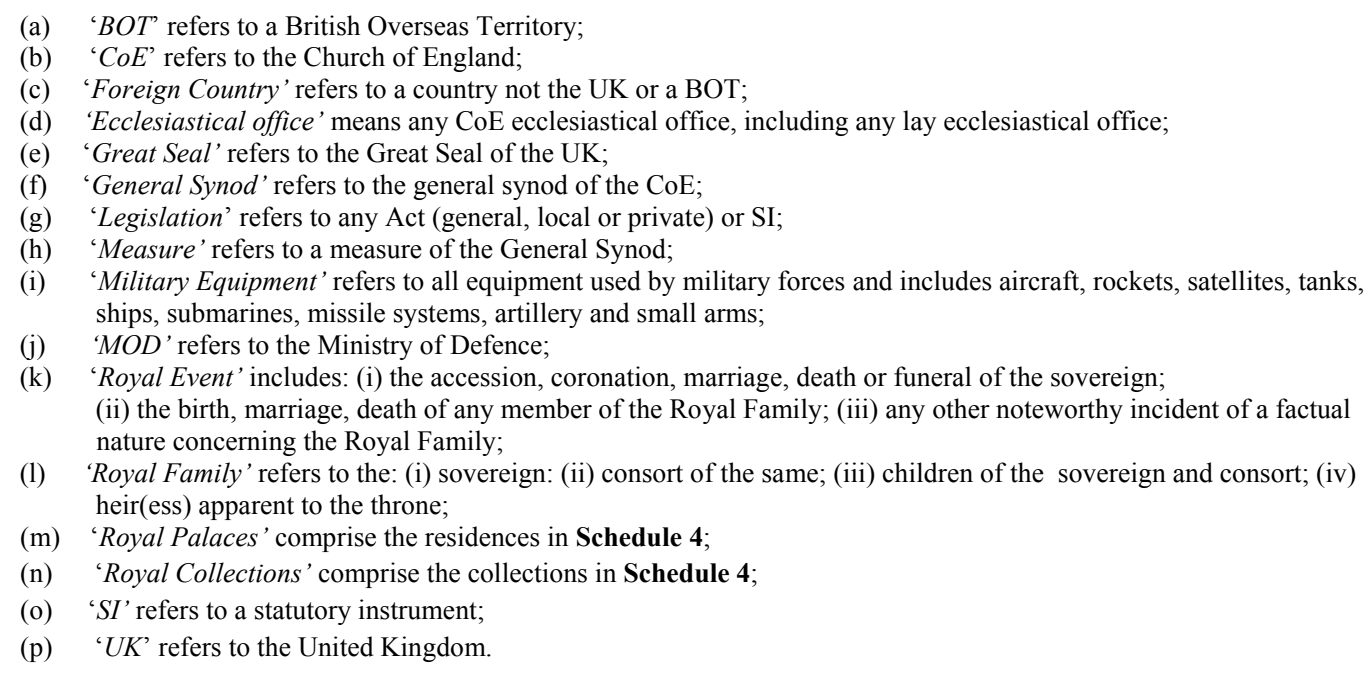

(2) In this Act reference to the:

(a) 'sovereign' refers to the sovereign in person (that is, in the body natural);

(b) 'Crown' refers to the sovereign as well as the same in the body politic, unless otherwise provided.

\section{Application}

(1) This Act applies to Scotland and Northern Ireland.

\section{Schedule 1: Regency}

\section{Regency while the Sovereign is under eighteen.}

(1) If the sovereign is, at his accession, under the age of eighteen years, then, until he attains that age, the royal functions shall be performed in the name and on behalf of the sovereign by a regent.

(2) For the purpose of any enactment requiring any oath or declaration to be taken, made, or subscribed, by the sovereign on or after his accession, the date on which the sovereign attains the age of eighteen years shall be deemed to be the date of his accession.

(3) The heir apparent or heir presumptive to the throne shall be deemed for all the purposes to be of full age if he or she has attained the age of eighteen years.

\section{Regency during total incapacity of the Sovereign.}

(1) If the following persons or any three or more of them, that is to say, the wife or husband of the sovereign, the Lord Chancellor, the Speaker of the House of Commons, the Lord Chief Justice of England, and the Master of the Rolls, declare in writing that they are satisfied by evidence which shall include the evidence of physicians that the sovereign is by reason 
of infirmity of mind or body incapable for the time being of performing the royal functions or that they are satisfied by evidence that the sovereign is for some definite cause not available for the performance of those functions, then, until it is declared in like manner that his Majesty has so far recovered his health as to warrant his resumption of the royal functions or has become available for the performance thereof, as the case may be, those functions shall be performed in the name and on behalf of the sovereign by a regent.

(2) A declaration under this section shall be made to the privy council and communicated to the governments of his Majesty's dominions [amend to refer to British Overseas Territories and to the former dominions of Canada, Australia and New Zealand].

\section{The Regent}

(1) If a regency becomes necessary [under this Act], the regent shall be that person who, excluding any persons disqualified under this section, is next in the line of succession to the Crown.

(2) A person shall be disqualified from becoming or being regent, if he is not a British subject of full age and domiciled in some part of the UK, or is a person who would, under section two of the Act of Settlement [1700], be incapable of inheriting, possessing, and enjoying the Crown, or is a person disqualified from succeeding to the Crown by virtue of section 3(3) of the Succession to the Crown Act 2013; and section 3 of the Act of Settlement [1700] shall apply in the case of a regent as it applies in the case of a sovereign.

(2) If any person who would at the commencement of a regency have become regent but for the fact that he was not then of full age becomes of full age during the regency, he shall, if he is not otherwise disqualified under this section, thereupon become regent instead of the person who has theretofore been regent.

(3) If the regent dies or becomes disqualified under this section, that person shall become regent in his stead who would have become regent if the events necessitating the regency had occurred immediately after the death or disqualification.

(4) Section two of this [Schedule] shall apply in relation to a regent with the substitution for references to the sovereign of references to the regent, and for the words "those functions shall be performed in the name and on behalf of the sovereign by a regent" of the words "that person shall be regent who would have become regent if the regent had died."

\section{Oaths to be taken by, and limitations of power of Regent.}

(1) The regent shall, before he acts in or enters upon his office, take and subscribe before the privy council the oaths set out below and the privy council are empowered, and required, to administer those oaths and to enter them in the council books.

1. I swear that I will be faithful and bear true allegiance to [here insert the name of the sovereign] his heirs and successors according to law. So help me God.

2. I swear that I will truly and faithfully execute the office of regent, and that I will govern according to law, and will, in all things, to the utmost of my power and ability, consult and maintain the safety, honour, and dignity of [here insert the name of the sovereign] and the welfare of his people. So help me God.

3. I swear that I will inviolably maintain and preserve in England and in Scotland the Settlement of the true Protestant religion as established by law in England and as established in Scotland by the laws made in Scotland in prosecution of the Claim of Right, and particularly by an Act intituled "An Act for Securing the Protestant Religion and Presbyterian Church Government" and by the Acts passed in the Parliament of both Kingdoms for Union of the two Kingdoms, together with the Government, Worship, Discipline, Rights, and Privileges of the Church of Scotland. So help me God. ${ }^{385}$

(2) The regent shall not have power to assent to any Bill for changing the order of succession to the Crown or for repealing or altering an Act of the fifth year of the reign of Queen Anne made in Scotland entitled "An Act for Securing the Protestant Religion and Presbyterian Church Government."

\section{Guardianship, \&c. of Sovereign during Regency}

(1) During a regency, unless Parliament otherwise determines,

(a) if the sovereign is under the age of eighteen years, and unmarried, his mother, if she is living, shall have the guardianship of his person

(b) if the sovereign, being married, is under the age of eighteen years or has been declared under this Act to be incapable for the time being of performing the royal functions, the wife or husband of the sovereign, if of full age, shall have the guardianship of the person of the sovereign;

(c) the regent shall, save in the cases aforesaid, have the guardianship of the person of the sovereign; and the property of the sovereign, except any private property which in accordance with the terms of any trust affecting it to be administered by some other person, shall be administered by the regent.

${ }^{385}$ This would no longer appear necessary. 


\section{Power to delegate royal functions to Counsellors of State}

(1) In the event of illness not amounting to such infirmity of mind or body as is mentioned in section two of this Act, or of absence or intended absence from the UK, the sovereign may, in order to prevent delay or difficulty in the despatch of public business, by letters patent under the great seal, delegate, for the period of that illness or absence, to counsellors of state such of the royal functions as may be specified in the letters patent, and may in like manner revoke or vary any such delegation: provided that no power to grant any rank, title or dignity of the peerage may be delegated.

(2) Subject as hereinafter provided, the counsellors of State shall be the wife or husband of the sovereign (if the sovereign is married), and the four persons who, excluding any persons disqualified under this section, are next in the line of succession to the Crown, of if the number of such persons next in the line of succession is less than four, then all such persons : provided that, if it appears to the sovereign that any person who, in accordance with the foregoing provisions of this subsection, would be required to be included among the counsellors of state to whom royal functions are to be delegated, is absent from the UK or intends to be so absent during the whole or any part of the period of such delegation, the letters patent may make provision for excepting that person from among the number of counsellors of state during the period of such absence.

(2A) The heir apparent or heir presumptive to the throne if not under the age of eighteen years shall not be disqualified from being a counsellor of state by reason only of his not being of full age, but save as aforesaid any person disqualified under this Act from being regent shall be disqualified from being a counsellor of state.

(3) Any functions delegated under this section shall be exercised jointly by the counsellors of state, or by such number of them as may be specified in the letters patent, and subject to such conditions, if any, as may be therein prescribed.

(4) The provisions of this section shall apply in relation to a regent with the substitution for references to the sovereign of references to the regent, so, however, that in relation to a regent subsection (2) of this section shall have effect as if after the word "next," where that word first occurs therein, there were inserted the words "after the regent". The provisions of this section shall apply in relation to a regent with the substitution for references to the sovereign of references to the regent and the omission, in subsection (2) thereof, of the reference to the wife or husband of the sovereign.

(5) Any delegation under this section shall cease on the demise of the Crown or on the occurrence of any events necessitating a regency or a change of regent.

7.

\section{[Interpretation].}

(1) In this [Schedule], save as otherwise expressly provided, the expression "royal functions" includes all powers and authorities belonging to the Crown, whether prerogative or statutory, [together with the receiving of any homage required to be done to His Majesty.]

\section{Schedule 2: Civil List}

The Civil List shall be administered according to the following sections: ${ }^{386}$

\section{The Sovereign Grant}

(1) A Sovereign Grant is to be paid by the Treasury to Her Majesty for each financial year.

(2) The purpose of the Sovereign Grant for a financial year is to provide resources for use for that year by the Royal Household in support of Her Majesty's official duties (see section 13).

(3) The amount of the Sovereign Grant for the financial year 2012-13 is $£ 31$ million.

(4) The amount of the Sovereign Grant for each subsequent financial year is the amount determined by the Royal Trustees for that year in accordance with section 6 .

(5) Section 9 (Duchy of Cornwall income) provides, in the circumstances mentioned there, for the amount of the Sovereign Grant to be reduced.

(6)The Sovereign Grant falls to be paid out of money provided by Parliament.

\section{Accounts of the Roval Household}

(1) The Keeper of Her Majesty's Privy Purse (referred to in this Act as "the Keeper") must keep proper accounting records relating to the Royal Household.

(2) As soon as practicable after the end of a financial year ("the financial year"), the Keeper must- (a) prepare a statement of accounts of the Royal Household for that year, and (b) give a copy of the statement to the Comptroller and Auditor General (referred to in this Act as "the Comptroller").

(3) The statement of accounts- (a) must state the amount of net relevant resources used for the financial year, and (b) subject to that, must be prepared in accordance with any directions given by the Treasury to the Keeper.

${ }^{386}$ This wording is the same as that in the Sovereign Grant Act 2011 with spent ss not included. 
(4) The directions that may be given include directions as to- (a) the information to be contained in the statement and how it is to be presented, (b) the methods and principles in accordance with which the statement is to be prepared, and (c) any additional information that is to accompany the statement.

(5) As soon as practicable after receiving the statement of accounts, the Comptroller must- (a)examine, certify and report on the statement, and (b)give a copy of the report and statement to the Treasury.

(6) The Treasury must- (a)lay a copy of the report and statement of accounts before Parliament, and (b)give a copy of the report and statement to the Royal Trustees.

(7) For the purposes of subsection (3)(a) the amount of net relevant resources used for a financial year is- (a) the amount of resources used for that year by the Royal Household in support of Her Majesty's official duties, minus (b) the amount of income of the Royal Household for that year (excluding the Sovereign Grant).

(8) For the purposes of Part 2 of the National Audit Act 1983 (economy, efficiency and effectiveness examinations) the Royal Household is to be treated as a body within section $6(3)(\mathrm{c})$ of that Act.

\section{The Reserve Fund}

(1) There is to be a Reserve Fund consisting of monies received by the Royal Trustees under this section and anything deriving from those monies.

(2) The Royal Trustees may invest any of the Reserve Fund in any way they consider appropriate.

(3) If the amount of the Sovereign Grant for a financial year exceeds the audited net relevant resources used for that year (see section 12), the Keeper must pay an amount equal to the excess to the Royal Trustees.

(4) If the audited net relevant resources used for a financial year exceeds the amount of the Sovereign Grant for that year, the Royal Trustees must pay from the Reserve Fund to the Keeper an amount equal to the excess (or, if less, an amount equal to the value of the Reserve Fund)

(5) At any time before the Comptroller has reported under section 2 on the statement of accounts of the Royal Household for a financial year-(a) the Keeper may make a payment to the Royal Trustees in respect of that year if the Keeper considers that a payment under subsection (3) would be required once the report has been made; (b) the Royal Trustees may make a payment from the Reserve Fund to the Keeper in respect of that year if they consider that a payment under subsection (4) would be required once the report has been made.

(6) If one or more payments under subsection (5) ("interim payments") are made in respect of a financial year, for the purposes of subsections (3) and (4)- (a) treat the amount of the Sovereign Grant for that year as reduced by the total amount of interim payments made under subsection (5)(a); (b) treat the amount of that Sovereign Grant as increased by the total amount of interim payments made under subsection $(5)(b)$.

(7) The Royal Trustees may make loans from the Reserve Fund to the Keeper for the purpose of enabling capital expenditure of the Royal Household to be met.

(8) In section 2(7)(b), the reference to income of the Royal Household does not include any payment under this section made to the Keeper.

\section{Accounts of the Reserve Fund}

(1) The Royal Trustees must keep proper accounting records of the Reserve Fund

(2) As soon as practicable after the end of a financial year ("the financial year"), the Royal Trustees must-(a) prepare a statement of accounts of the Reserve Fund for that year, and (b) give a copy of the statement to the Comptroller.

(3)The statement of accounts-(a) must state the value of the Reserve Fund at the end of the financial year, and(b) subject to that, must be prepared in accordance with any directions given by the Treasury to the Royal Trustees.

(4)The directions that may be given include directions as to- (a) the information to be contained in the statement and how it is to be presented,(b) the methods and principles in accordance with which the statement is to be prepared, and (c) any additional information that is to accompany the statement.

(5) As soon as practicable after receiving the statement of accounts, the Comptroller must- (a) examine, certify and report on the statement, and(b)give a copy of the report and statement to the Treasury.

(6) The Treasury must lay a copy of the report and statement of accounts before Parliament.

(7) For the purposes of Part 2 of the National Audit Act 1983 (economy, efficiency and effectiveness examinations)-(a) the Royal Trustees are to be treated as a body within section 6(3)(c) of that Act, and(b) for the purposes of section 6(4) of that Act the functions of the Comptroller in relation to the Royal Trustees are to be regarded as restricted to matters relating to the Reserve Fund.

\section{Annual report as to the amount of Sovereign Grant}

(1) In each financial year the Royal Trustees must prepare a report-(a) stating their determination in accordance with section 6 of the amount of the Sovereign Grant for the following financial year, and (b) setting out how that amount has been determined.

(2) The report must be prepared as soon as practicable after the Comptroller has done all of the following- (a) reported under section 2 on the statement of accounts of the Royal Household for the previous financial year, (b) reported under section 4 on the statement of accounts 
of the Reserve Fund for that year, and (c) reported under section 2 of the Crown Estate Act 1961 on the statement of accounts for that year prepared by the Crown Estate Commissioners under that section.

(3) The Royal Trustees must give a copy of the report to the Treasury.

(4) The Treasury must lay a copy of the report before Parliament.

\section{Determination of the amount of Sovereign Grant}

(1) The amount of the Sovereign Grant for a financial year ("the relevant financial year") is to be determined by the Royal Trustees as follows-

Step 1 Calculate $125 \%$ of the income account net surplus of the Crown Estate (see section 12) for the base year."The base year" means the financial year that begins two years before the beginning of the relevant financial year.

Step 2 Round the amount calculated under Step 1 up to the nearest $£ 100,000$.

Step 3 Find the greater of-

(a) the amount determined under Step 2, and (b) the amount of the Sovereign Grant for the financial year that immediately precedes the relevant financial year.

That amount is "the Step 3 amount".

Step 4 If the adjusted value of the Reserve Fund at the end of the base year (see subsection (2)) exceeds $50 \%$ of the audited net relevant resources used for that year, the Royal Trustees may reduce the Step 3 amount by such amount as they consider appropriate (but see subsection (4)).

Step 5 The amount of the Sovereign Grant for the relevant financial year is-(a) the Step 3 amount, or

(b) if Step 4 applies, the Step 3 amount as reduced by the reduction (if any) made under Step 4.

(2) The "adjusted value" of the Reserve Fund at the end of a financial year is the value of the Reserve Fund at the end of that year (see section 12) - (a)increased by the amount of relevant payments made to the Fund, and (b)reduced by the amount of relevant payments made from the Fund.

(3) In subsection (2) "relevant payment", in relation to a financial year, means a payment under section 3(3), (4) or (5) that -(a)is made after the end of that year but in respect of that year, and(b)is not reflected in the statement of accounts of the Reserve Fund for that year.

(4) The Royal Trustees must, in exercising their power under Step 4, act in a way they expect will result in the adjusted value of the Reserve Fund at the end of the relevant financial year being about $50 \%$ of the audited net relevant resources used for that year.

\section{Review by Royal Trustees of Sovereign Grant}

(1) As soon as practicable after the end of a review period, the Royal Trustees must review whether the percentage for the time being specified in Step 1 of section 6(1) is appropriate.

(2)They must prepare a report that- (a)states whether they consider that the percentage is or is not appropriate, (b) if they consider that it is not appropriate, states the percentage that they consider should apply, and (c) gives an explanation of their conclusions.

(3)The Royal Trustees must give a copy of the report to the Treasury.

(4)The Treasury must lay a copy of the report before Parliament.

(5)The review periods are- (a) the period of 4 years beginning with 1 April 2012, and (b) every period of 5 years beginning at the end of another review period.

\section{Power to change level of Sovereign Grant}

(1) This section applies where a report under section 7 states that the Royal Trustees consider that the percentage for the time being specified in Step 1 of section 6(1) is not appropriate.

(2)The Treasury must by order made by statutory instrument substitute, for that percentage, the percentage specified by the Royal Trustees in the report as the one that should apply.

(3) A statutory instrument containing an order that increases the percentage specified in Step 1 of section 6(1) may be made only if a draft of the instrument has been laid before and approved by a resolution of the House of Commons.

(4) Any other statutory instrument under this section is subject to annulment in pursuance of a resolution of the House of Commons.

\section{Duchy of Cornwall income and grant to the heir to the throne}

(1)Where the Duke of Cornwall for the time being is under 18 for any period in a financial year- (a) the amount of the Sovereign Grant for that year is reduced by an amount equal to $90 \%$ of the income account net surplus of the Duchy of Cornwall for that period, and (b) the income of the Duchy of Cornwall for that year, up to the amount by which the Sovereign Grant is reduced under paragraph (a), is to be at the disposal of Her Majesty.

(2)Where the Duchy of Cornwall is vested in Her Majesty for any period ("the relevant period") in a financial year (and Her Majesty is accordingly entitled to its income) - (a)the amount of the Sovereign Grant for that year is reduced by an amount equal to the income account 
net surplus of the Duchy of Cornwall for the relevant period, and (b)the Treasury is to pay a grant to any person who is the heir to the throne in the relevant period.

(3)The amount of the grant paid to any person is- (a) for any period (falling within the relevant period) when the person is the heir and is aged 18 or over, the amount by which the Sovereign Grant is reduced for that period, and (b) for any period (falling within the relevant period) when the person is the heir and is under $18,10 \%$ of the amount by which the Sovereign Grant is reduced for that period.

(4)Where the grant under subsection (2)(b) would (apart from this subsection) be paid to a person who is under 18 at the time of payment, the grant is to be paid to the Royal Trustees and is to be held by them on trust for the person on such terms as the Treasury may direct.

(5)Any reduction in the amount of the Sovereign Grant under this section is to be ignored for the purposes of - (a) section 3 (the Reserve Fund), and (b)Step 3 in section 6(1) (determination of amount of Sovereign Grant).

(6) Where the amount of the Sovereign Grant for a financial year is reduced under this section, references in section 2(7)(b) (income of the Royal Household) and section 11 (maintenance of Royal Palaces) to the Sovereign Grant include income of the Duchy of Cornwall for that year.

(7) For the purpose of determining the income account net surplus of the Duchy of Cornwall for part of a financial year, the income account net surplus of the Duchy for the whole of that year is to be apportioned equally in respect of each day of that year.

(8) For the purpose of determining the amount by which the Sovereign Grant is reduced for part of the relevant period, the reduction under subsection (2)(a) is to be apportioned equally in respect of each day of that period.

(9) For the purpose of making reductions under subsection (1)(a) or (2)(a), and paying grants under subsection (2)(b), in respect of a financial year (or part of a financial year) - (a) until the accounts of the Duchy of Cornwall for that year have been submitted to the Treasury pursuant to section 2 of the Duchies of Lancaster and Cornwall (Accounts) Act 1838, the Treasury is to act on the basis of its estimate of the amount of the income account net surplus of the Duchy of Cornwall for that year, and (b) any necessary adjustments (including any payments or repayments) are to be made after those accounts have been submitted.

(10) The grant under subsection (2)(b) falls to be paid out of money provided by Parliament.

\section{Maintenance of Roval Palaces and related land}

The Secretary of State has no duties under section 21 of the Crown Lands Act 1851 in relation to the maintenance of Royal Palaces and related land so far as they are maintained by Her Majesty out of the Sovereign Grant.

\section{Meaning of "the audited net relevant resources", "the value of the Reserve Fund" and "the income account net surplus of the Crown Estate"}

(1) For the purposes of this Act-

"the audited net relevant resources" used for a financial year are the amount of net relevant resources used for that year stated in the statement of accounts certified by the Comptroller under section 2,

"the value of the Reserve Fund" at the end of a financial year is the value of the Reserve Fund at the end of that year stated in the statement of accounts certified by the Comptroller under section 4 , and

"the income account net surplus of the Crown Estate" for a financial year is the amount of that surplus stated in the statement of accounts

certified by the Comptroller under section 2 of the Crown Estate Act 1961; but this is subject to subsection (2).

(2) If a relevant report on a statement of accounts contains a qualification (however expressed) that affects or might affect the amount or value stated in the statement as the amount or value of a relevant figure- (a) the Comptroller must certify in the relevant report the amount or value which the Comptroller considers to be the amount or value of the relevant figure, and (b) for the purposes of this Act the relevant figure is to be taken to be the amount or value certified.

(3)For this purpose-

"relevant report" means a report made by the Comptroller under section 2 or 4 of this Act or section 2 of the Crown Estate Act 1961 , and

"relevant figure" means - (a) the amount of net relevant resources used for a financial year, (b) the value of the Reserve Fund at the end of a financial year, or (c) the amount of the income account net surplus of the Crown Estate for a financial year.

\section{Other interpretative provisions etc}

(1) This section applies for the purposes of this Act.

(2)“The Comptroller” has the meaning given by section 2 .

(3)“Financial year” means a year beginning with 1 April.

(4)“The financial year 2012-13" means the financial year beginning with 1 April 2012, and similar expressions are to be read accordingly. 
(5)“The Keeper” has the meaning given by section 2 .

(6)“The Reserve Fund" means the Reserve Fund established by section 3.

(7)“The Royal Trustees" means the body established by section 10 of the Civil List Act 1952.

(8) Any reference to the support of Her Majesty's official duties includes the maintenance of Royal Palaces and related land.

(9) Any reference to the Royal Household is limited to that Household so far as it is concerned with the support of Her Majesty's official duties.

(10) Any reference to the use of resources is to their expenditure, consumption or reduction in value.

(11) Any direction under this Act may be varied or revoked by another direction.

\section{Duration of Sovereign Grant provisions etc}

(1) The Sovereign Grant provisions cease to have effect 6 months after the end of the present reign unless continued under subsection (3).

(2)“The Sovereign Grant provisions” are sections 1 to 9,11 and 12 .

(3) An Order in Council may provide that, instead of expiring when they would otherwise expire (by virtue of subsection (1) or a previous Order under this subsection), the Sovereign Grant provisions expire 6 months after the end of the reign in which the Order is made.

(4) In section 1(1) of the Civil List Act 1952 (payment of hereditary revenues into the Consolidated Fund) for "during the present reign and a period of six months afterwards" substitute "while section 1 of the Sovereign Grant Act 2011 is in force ".

(5)Sections 5 and 6 of the Civil List Act 1837 (honorific pensions) have permanent effect.

(6)The sums required for the payment of pensions under section 5 of that Act (whether granted before or after the passing of this Act) are to be charged on and paid out of the Consolidated Fund.

\section{Pensions ${ }^{387}$}

(1) The Treasury shall issue out of the Civil List a pension at the rate of $£ 15,000$ a year (or such other sum as may be specified in a SI), to persons who by their:

(a) personal service to the Crown; or

(b) performance of duties to the public; or

(c) useful discoveries in science and attainments in literature and the arts,

have merited the gracious consideration of their sovereign and the gratitude of their country. ${ }^{388}$

(2) A list of all pensions granted pursuant to sub-section (1) in each year ending on the $31^{\text {st }}$ March shall be laid before Parliament within 30 days after that date in each year, if Parliament is sitting. If not, within 30 days after the next meeting of Parliament. ${ }^{389}$

[Note: Since pensions are now only given pursuant to ss (1)(c), it may be appropriate to delete (a) and (b). Further, since the role of the sovereign in such matters is now formal, the words 'the gracious consideration of their sovereign and' may be deleted.

\footnotetext{
${ }^{387}$ This wording is taken from the Civil List Act 1837, with the wording modernised.

${ }^{388}$ The original Civil List Act 1837, s 5 states: (1,2001. a year to be issued to defray the charges of pensions). And whereas it is expedient to make provision, at the rate of $£ 15,000$ a year for each and every succeeding year... to defray the charge of such pensions payable under this section as may be granted by [HM]: Be it therefore enacted, that it shall be lawful for the Treasury to charge upon and issue quarterly out of the said consolidated fund... such sums as shall be required to defray the charge of such pensions as may be granted as aforesaid, at the rate of $£ 15,000$ a year for every succeeding year.

${ }^{389} \mathrm{Ibid}$, 6 (restrictions on grants of pensions). List of pensions granted to be laid before Parliament yearly. And whereas it was resolved by the Commons House of Parliament, on the [18 Feb 1834], "that it is the bounden duty of the responsible advisers of the Crown to recommend to [HM] for grants of pensions on the civil list such persons only as have just claims on the royal beneficence, or who by their personal services to the Crown, by the performance of duties to the public, or by their useful discoveries in science and attainments in literature and the arts, have merited the gracious consideration of their sovereign and the gratitude of their country" : And whereas it is expedient that provision should be made by law for carrying into full effect the said resolution, and for giving an assurance to Parliament that the responsible advisers of the Crown have acted in conformity therewith: the pensions which may hereafter be granted as mentioned in section 5 shall be granted to such persons only as have just claims on the royal beneficence, or who by their personal services to the Crown, by the performance of duties to the public, or by their useful discoveries in science and attainments in literature and the arts, have merited the gracious consideration of their Sovereign and the gratitude of their country; and that a list of all such pensions granted in each year ending the [31 $1^{\text {st }}$ March] shall be laid before Parliament within [30] days after the said [31 March] in each year, if Parliament shall be then sitting, but if Parliament shall not be then sitting, then within [30] days after the next meeting of Parliament.
} 


\section{Schedule 3: Abolished Prerogatives}

All the prerogatives set out in this Schedule are abolished, as described:

\section{Military Prerogatives}

(1) The following are abolished, any Crown prerogative (and any franchise) to:

(a) billet any member of the armed forces on the general public;

(b) impose martial law (including the jurisdiction of courts martial) on civilians;

(c) impress civilian subjects for military service;

(d) issue letters of marque and reprisal;

(e) dig for saltpetre (for gunpowder);

(f) enter private land to dig for saltpetre;

(g) castellate (that is, to build a castle or fortified residence);

(h) erect military fortifications on private land;

(i) impose a toll for murage (to build city or town defensive walls).

\section{Prerogatives concerning Animals and Fish}

(1) The following are abolished, any Crown prerogative (and any franchise, save where (2) provides) to wild, unmarked, swans on the sea or the branches thereof ('royal swans') save for wild, unmarked, swans on the river Thames.

(2) The following franchisees retain a right to wild, unmarked, swans, the:

(a) Company of Vintners (only for swan upping on the Thames);

(b) Company of Dyers (only for swan upping on the Thames);

(c) Ilchester family (for the swan breeding colony at Abbotsbury in Dorset).

\section{Prerogatives concerning Mines}

(1) The following are abolished, any Crown prerogative to gold and silver mines ('royal mines').

\section{Commercial Prerogatives}

(1) The following are abolished, any Crown the prerogative (and any franchise) to:
(a) treasure trove;
(b) dig for treasure trove on private land;
(c) wreck (as well as flotsam, jetsam and ligan);
(d) create or dissolve a chartered corporation;
(e) amend the charter of a chartered corporation;
(f) confer a power on a chartered corporation to make byelaws;
(g) operate any market or fair;
(h) operate any ferry within the UK (that is, any domestic ferry);
(i) charge any customary rate or toll;
(j) regulate weights and measures;
(k) license a commercial monopoly;
(l) grant a patent for any invention.

(2) In the case of ((d), (e) and (f), a SI may: (i) create a corporation; (ii) amend the charter of a chartered corporation; (iii) grant power to a chartered corporation to amend its byelaws; (iv) dissolve a chartered corporation or one established pursuant to (i).

(3) In the case of any franchise of (g) and (h) asserted to still exist, the same may be preserved by the Department of Environment (in the case of a market or fair) or the Department for Transport (in the case of a domestic ferry) for an interim period of one year, in order for any market, fair or domestic ferry (if necessary) to become regulated by legislation (including a SI). If not legislated for, the franchise (and any right to the same) shall lapse on the date stipulated by the said Departments.

(4) In the case of any customary rate or toll referred to in (i) asserted to still exist, such may be preserved in the same manner as in (3) by the Department of Environment (or the Department for Transport or other relevant Government department).

(5) 'Toll' shall include any: (a) bridge toll (pontage); (b) road toll (including for pavage and passage as well as toll thorough and toll traverse); (c) ferry toll; (d) market toll (including for stallage, piccage, pennage, tronage, scavage, lastage, summage, toll turn); (e) port and water related toll (including for carriage, wharfage, anchorage, ballastage, keelage, moorage, terrage, hostellage, pesage, tronage, measurage, lastage, loadage, primage, groundage); (f) any forest and animal toll (including for cheminage, boscage, pannage, herbage).

\section{Border Prerogatives}

(1) The following are abolished, any Crown prerogative to: 
(a) issue a letter of safe conduct;

(b) prohibit a subject from leaving the realm (including by means of the writ ne exeat regno);

(c) order a subject to return to the realm.

\section{Prerogatives concerning Prisons}

(1) The following are abolished, any Crown prerogative (and any franchise) to:
(a) establish a new prison;
(b) operate a prison;
(c) franchise the operation of a prison.

\section{Prerogatives concerning Coinage}

(1) The following are abolished, any Crown prerogative (and any franchise) to:

(a) issue (that is, mint) coin of the realm and to fix its denomination (or value) and render it current;

(b) legitimate foreign coin;

(c) decry coin of the realm, making it no longer current.

(2) A SI may authorise any of 1(a)-(c).

\section{Prerogatives concerning the Printing of Books}

(1) The following is abolished, any Crown prerogative (and any franchise) to have the sole right (monopoly) to print any book

(2) The Copyright, Design and Patents Act 1988, s 164 (1) is amended to include reference to the following:
(a) the Authorised Version of the Bible;
(b) the Book of Common Prayer; ${ }^{390}$
(c) such State papers and documents as are specified in a SI.

\section{Prerogatives concerning the Sea}

(1) The following are abolished, any Crown prerogative (and any franchise) to:
(a) establish a public port or harbour (haven)
(b) regulate a public port or harbour (haven);
(c) charge for services provided at (a);
(d) erect a lighthouse or beacon as a sea mark, including on the land of a subject without consent.

\section{General Constitutional Prerogatives}

(1) The following are abolished, any Crown prerogative to:
(a) create a county palatine;
(b) create a county corporate or royal county corporate;
(c) grant the status of a city;
(d) grant the status of a borough or royal borough;
(e) grant the status of a town or royal town.

\section{Prerogatives as Parens Patriae}

(1) The following are abolished, any Crown prerogative to supervise (including any power of visitation):
(a) the person, and estate, of a minor;
(b) the person, and estate, of any mentally ill person;
(c) any charity.

(2) In the cases of (1), supervision of the same (to the extent still existing) shall pass from the Crown to Government departments (or other bodies or legal persons) as provided for in an SI.

\section{Prerogatives as to Honours, Styles and Titles}

(1) The following are abolished, any Crown prerogative to create:

(a) a hereditary peerage (including the style and title of duke, earl, marquis, viscount or baron); ${ }^{391}$

(b) the style and title of lord mayor or mayor (or deputy lord mayor or mayor)

\footnotetext{
${ }^{390}$ It may be that the CoE no longer require this monopoly.

${ }^{391}$ Reference could also be made to any new life peerage.
} 
without prejudice to any of (a) or (b) presently existing.

(2) The following coutesy titles are abolished, the style and title of:

(a) 'right honorable';

(b) 'esquire'.

\section{Legal Prerogatives - Courts and Commissions}

(1) The following are abolished, any Crown prerogative to create any:

(a) common law court;

(b) commission exercising a judicial function.

\section{Legal Prerogatives - Construction of Crown Grants}

(1) The following are abolished, any Crown prerogative to:

(a) have a Crown grant construed in favour of the Crown;

(b) have a lost Crown grant presumed;

(c) be presumed to be deceived (or mistaken) in a Crown grant;

(d) be presumed, in a Crown grant, to reserve an advowson;

(e) re-enter, on a default under a Crown lease, without having to make a demand (or to give any notice). ${ }^{392}$

\section{Other Legal Prerogatives}

(1) The following are abolished, any Crown prerogative to:

(a) exercise any prerogative with regard to a right of distress, ${ }^{393}$

(b) not have to give a receipt (an acquittance) acknowledging the payment (or the discharge) of any debt to the Crown;

(c) not be bound by an estoppel;

(d) not be bound by any legal fictions;

(e) compel a person to accept a public office.

\section{Personal Prerogatives}

(1) The following are abolished, any prerogative of the sovereign in person to:
(a) sit as a judge;
(b) withdraw a case from a court (that is, order a court to refuse to hear it);
(c) order a court to delay giving judgment;
(d) sue in whatever court the sovereign pleases;
(e) use special forms of court procedure including proceeding by way of: (i) information; (ii) inquisition or inquest of office; (iii) extent; (iv) scire facias; (v) quo warranto; (vi) mandamus;
(f) not pay (or receive) legal costs;
(g) have their personal property exempt in the case of: (i) wreck; (ii) estrays; (iii) waifs; (iv) customary rates and tolls ${ }^{394}(v)$ distress for rent;
(h) be exempt from the enforcement of any lien, pledge or debt in execution against the sovereign;
(i) approve the marriage of a queen dowager;
(j) exempt a person from any liability imposed by legislation or the common law;
(k) pardon or reprieve a person;
(l) act as visitor in the case of a chartered corporation;
(m) dispose of the Crown jewels, by way of a life interest, by letters patent.

\section{Prerogatives in connection with the Bill of Rights $\mathbf{1 6 8 8}$}

(1) The following are abolished, any Crown prerogative of the Crown:
(a) restrict a subject's right to petition the Crown;
(b) interfere in the grant of bail by a court;
(c) interfere in the punishment awarded by a court;
(d) interfere in the fining of a person by a court (including the amount of the fine);
(e) interfere in the selection (or empanelling) of a jury;
(f) franchise any court fine.

(2) The following are abolished, any Crown prerogative to suspend, or dispense, with:

\footnotetext{
${ }^{392}$ This is also dealt with in the Act, Prerogativa Regis (c. 1324), which this Crown Act seeks to abolish.

${ }^{393}$ Common law distress has been abolished. Thus, this may not be needed.

${ }^{394}$ This Act seeks to abolish these anyway.
} 
(a) legislation (including by way of non obstante); or

(b) the common law; or

(c) the operation of (a) or (b)

\title{
18. Prerogatives in connection with the Act of Settlement 1700
}

(1) The following are abolished, any prerogative of the Crown to:

(a) plead the grant of a pardon under the Great Seal to an impeachment by the Commons in Parliament. ${ }^{395}$

\section{Schedule 4: Roval Palaces and Roval Collections}

(a) Royal Palaces

\author{
Bagshot Park \\ Buckingham Palace \\ Hampton Court Palace \\ Hillsborough Castle \\ Frogmore House \\ Kensington Palace \\ Kew Palace \\ Palace of Holyroodhouse \\ Thatched House Lodge \\ The Banqueting House, Whitehall \\ The Royal Lodge \\ Tower of London \\ St James' Palace \\ Windsor Castle
}

\section{(b) Royal Collections}

Collections administered by the Royal Collections Trust

Royal Philatelic Collection

Royal Carriages

(c) Osborne Estate

(1) The estate described on the deposited plans (the 'Osborne Estate') is vested in the sovereign in right of the Crown.

(2) The part of the estate, coloured blue on the deposited plans (being Osborne House and grounds adjacent thereto) shall be under the management of the Commissioners of Works and arrangements may at any time be made, with the consent of the Treasury, for placing any part of the Osborne estate under such management, or for withdrawing any part from such management as appears convenient at the time.

(3) As a memorial to Queen Victoria, the Commissioners of Works shall preserve, so far as may be, in its present condition, and keep open to the public, in such manner and on such terms as the Commissioners determine, such part of Osborne House as appears to have been in the personal occupation of Queen Victoria

\section{Schedule 5: Roval Household}

\section{$\underline{\text { Part A: Present Office and Title }}^{396}$}

Lord Chamberlain

Private Secretary

Keeper of the Privy Purse and Treasurer to the Queen

Master of the Household

Comptroller, Lord Chamberlain's Office

Director, Royal Collection Trust and Surveyor of the Queen's Works of Art

Crown Equerry

Director of Royal Communications

Director of the Property Section

Secretary of the Central Chancery of the Orders of Knighthood

\section{Part B: New Office and Title}

Lord Chamberlain

Queen's Private Secretary

Queen's Treasurer

Head, Royal Household

Head, Lord Chamberlain's Office

Director, Royal Collections

Director, Royal Carriages

Director, Communications

Director, Property

Director, Orders of Chivalry

395 The process of impeachment may be obsolete. Thus, this provision may not be needed.

${ }^{396}$ In the House of Common there are also represented the: (a) Treasurer of HM Household; (b) Comptroller of HM Household; (c) ViceChamberlain of HM Household. 
Marshal of the Diplomatic Corps Director of Operations, Royal Travel

\section{$\underline{\text { Part C }}$}

Master of the Queen's Music

Poet Laureate

Lord High Almoner

Hereditary Grand Almoner

Clerk of the Closet

Deputy Clerk of the Closet

\section{Part A : Main Orders}

\section{Orders of Knighthood}

Order of the Garter

Order of Merit

rder of the Companions of Honour

Order of the Companions of Honour

3. Medals

\section{Decorations}

Conspicuous Gallantry Cross ${ }^{398}$

Military Cross

Royal Red Cross (class 1)

Distinguished Service Cross

Distinguished Flying Cross Air Force Cross

Distinguished Conduct Medal (DCM)

George Medal (GM) $)^{399}$

Military Medal (MM)
Director, Diplomatic Corps

Director, Royal Travel
Order of St Patrick

Order of the Star of India

Order of the Indian Empire

Order of the Crown of India

Royal Victorian Orde

Distinguished Service Order

Royal Victorian Order (4 ${ }^{\text {th }}$ class)

Order of the British Empire (4 ${ }^{\text {th }}$ class)

Imperial Service Order

Royal Victorian Order ( $5^{\text {th }}$ class $)$

Order of the British Empire $\left(5^{\text {th }}\right.$ class $)$

Indian Order of Merit (Military) Conspicuous Gallantry Medal (CGM)

Conspicuous Gallantry Medal (Flying)

Royal Red Cross (class II)

Order of British India

Kaisar-i-Hind Medal

Order of St John

Union of South Africa Queen's Medal for Bravery

Queen's Police Medal for Gallantry

Queen's Fire Service Medal for Gallantry

Royal West African Frontier Force DCM

King's African Rifles DCM

Indian Distinguished Service Medal

Distinguished Service Medal

${ }^{397}$ Consideration should be given to repealing these.

398 The civil version of the military cross.

399 The civil version of the military medal. 
Distinguished Flying Medal (DFM) Air Force Medal (AFM)

Medal for Saving Life at Sea (Sea Gallantry Medal) Indian Order of Merit (Civil) Indian Medal for Gallantry Ceylon Medal for Gallantry Sierra Leone Police Medal for Gallantry Sierra Leone Fire Brigades Medal for Gallantry Overseas Territories Medal for Gallantry Queen's Gallantry Medal (QGM) Royal Victorian Medal (RVM) British Empire Medal (BEM)

Canada Medal Queen's Police Medal for Distinguished Service (QPM)

Queen's Fire Service Medal for Distinguished Service (QFSM)

Queen's Volunteer Reserve Medal Queen's Medal for Chiefs

\section{Efficiency \& Long Service Decorations}

Medal for Meritorious Service ('MS')

Medal for Long Service \& Good Conduct ('LS\&GC')(Military)

Accumulated Campaign Service Medal

Naval LS\&GC Medal

Medal for MS (Royal Navy 1918-28)

Indian LS\&GC Medal

Indian MS Medal

Royal Marines MS Medal (1849-1947)

Royal Air Force (MS Medal) (1918-28)

Royal Air Force (LSGC) Medal

Medal for LS\&GC (Ulster Defence Regiment)

Indian LS\&GC Medal

Royal West African Frontier Force LS\&GC Medal

Royal Sierra Leone Military Forces LS\&GC Medal

King's African Rifles LS\&GC Medal

Indian MS Medal

Police LS\&GC Medal

Fire Brigade LS\&GC Medal

African Police Medal for MS

Royal Canadian Mounted Police Long Service ('LS') Medal

Ceylon Police LSM

Ceylon Fire Services LS Medal

Sierra Leone Police LSM

Overseas Territories Police LSM

Sierra Leone Fire Brigades LSM

Mauritius Police LS\&GC Medal

Mauritius Fire Services LS\&GC Medal

Mauritius Prisons Service LS\&GC Medal

Overseas Territories Fire Brigades LSM

Overseas Territories Prison Service Medal

HK Disciplined Services Medal

Army Emergency Reserve Decoration (ERD)

Volunteer Officers' Decoration (VD)

Volunteer LS Medal

Volunteer Officers’ Decoration (India \& Colonies)

Volunteer LS Medal (India \& Colonies)

Colonial Auxiliary Forces Officers' Decoration

Colonial Auxiliary Forces LS Medal

Medal for Good Shooting (Naval)

Militia LS Meda

Imperial Yeomanry LS Medal

Territorial Decoration (TD)

Ceylon Armed Services LS Medal

Efficiency Decoration (ED)

Territorial Efficiency Medal

Efficiency Medal

Special Reserve LS\&GC Medal

Decoration for Officers of the RN Reserve (RD)

Decoration for Officers of the RN Volunteer Reserve (VRD)

RN Reserve LS\&GC Medal

RN Auxiliary Sick Berth LS\&GC Medal

Royal Fleet Reserve LS\&GC Medal 
RN Wireless Auxiliary Reserve LSGC Medal

RN Auxiliary Service Medal

Air Efficiency Award (AE)

Volunteer Reserves Service Medal

Ulster Defence Regiment Medal

NI Home Service Medal

Queen's Medal (Champion Shots of RN \& RM

Queen's Medal (Champion Shots of NZ Naval Forces)

Queen's Medal (Champion Shots of Air Forces)

Cadet Forces Medal

HM Coastguard LS\&GC Medal

Special Constabulary LS Medal

Canadian Forces Decoration

Royal Observer Corps Medal

Civil Defence LS Medal

Ambulance Service (Emergency Duties) LS\&GC Medal

Royal Flee Auxiliary Service Medal

Prison Services (Operational Duties) LS\&GC Medal

Jersey Honorary Police LS\&GC Medal

Merchant Navy Medal for Meritorious Service

Ebola Medal for Service in West Africa

National Crime Agency LS\&GC Medal

Rhodesia Medal

Royal Ulster Constabulary Service Medal

NI Prison Service Medal

Union of South Africa Commemoration Medal

Indian Independence Medal

Pakistan Medal

Ceylon Armed Services Inauguration Medal

Ceylon Police Independence Medal

Sierra Leone Independence Medal

Jamaica Independence Medal

Uganda Independence Medal

Malawi Independence Medal

Fiji Independence Medal

Papua New Guinea Independence Medal

Solomon Islands Independence Medal

Service Medal of the Order of St John

Badge of the Order of the League of Mercy

Voluntary Medical Service Medal

Women's Royal Voluntary Service Medal

South African Medal for War Services

Overseas Territories Special Constabulary Medal

Schedule 7: Obsolete Titles and Offices

(a) Lord High Admiral;

(b) Lord High Admiral of the Wash;

(c) Lord Admiral;

(d) Vice-Admiral of the Coast;

(e) First and Second Lords of the Admiralty;

(f) Any other admiralty post which is non-operational (that is, one of active service);

(g) Lord Lieutenant (also, any vice, deputy or lieutenant of the same);

(h) Lord High Constable;

(i) Lord High Constable of Scotland;

(j) Earl Marshall (also, any deputy);

(k) Earl Marshal of Ireland;

(1) Earl Marischal of Scotland;

(m) Vice-Gerent;

(n) High Sheriff (also, any under-sheriff, deputy or London deputy)

(o) Clerk of the Market;

(p) Lord High Treasurer (also, called the Lord Treasurer);

(q) First and Second Lord of the Treasury;

(r) King's Secretary (also, called the Chief Secretary)(also, any deputy);

(s) Paymaster General (and Assistant);

(t) Chancellor of the Duchy of Lancaster;

(u) President of the Board of Trade;

(v) Lord Keeper of the Privy Seal;

(w) Lord Keeper of the Privy Seal of Scotland;

(x) Lord Clerk Register of Scotland;

(y) Lord High Steward;

(z) Lord High Steward of Ireland;

(aa) Clerk of the Crown;

(bb) Hereditary Usher of the White Rod (or Principal Usher) for Scotland;

(cc) Hereditary Royal Standard Bearer for Scotland; 
(dd) Master of the Horse;

(ee) Lord Steward of the Household (also, called the Lord Steward);

(ff) Lord High Chamberlain (also, called the Lord Great Chamberlain);

(gg) Lord High Chamberlain (Scotland);

(hh) in respect of the Lord Mayor of the City of London:

(i) Escheator of the City of London;

(ii) Admiral of the Port of London;

(iii) Chief Magistrate of the City of London;

(iv) Gauger of the City of London;

(v) Clerk of the Market of the City of London

(vi) Coroner of the City of London;

(vii) Registrar of Pawns in the City of London;

(viii) Outroper (crier) of the City of London;

(ix) Keeper of the Great Beam of the City of London.

(ii) High Steward (and deputy)

(ji) Common Sarjeant of London

(kk) Recorder of London

(11) Queen's Champion

(mm) Chief Butler of England

(nn) Grand Carver of England

(oo) Lord or Lady Marcher

(pp) Lord Warden of the Stannaries

(qq) Searcher of the Sanctuary, Westminster Abbey

(rr) High Steward, Westminster Abbey

(ss) Keeper of the Signet

(tt) Hereditary Royal Falconer

(uu) Queen's Guide over the Kent Sands. ${ }^{400}$

\section{Schedule 8: Coronation Declaration}

Declaration to be delivered by the archbishop or bishop:

'Do you promise to govern the peoples of the United Kingdom of Great Britain and Northern Ireland, Canada, Australia, New Zealand and your other territories according to their respective laws and customs ?'

Sovereign: 'I promise.'

'Do you promise to cause law and justice to be executed in all your judgements?'

Sovereign: 'I promise.'

\section{Schedule 9: Duchy of Cornwall - Manors and Rivers}

(a) Manors

Helston-in-Trigg
Penmayne
Tintagel
Restormel
Penlyne
Penkneth
Talskedy
Liskeard
Rillaton
Stoke Climsland
Trematon.

(b) Rivers

[Duchy to provide details and legislative source].

\section{Schedule 10: Duchy of Cornwall - Management Acts}

This Schedule [ or a SI] will set out the provisions of the following Acts, as modernised:

Duchies of Lancaster and Cornwall (Accounts) Act 1838

Duchy of Cornwall Act 1844

${ }^{400}$ Those from (mm)-(vv) are sinecures listed in A Bruce, Keepers of the Kingdom. The Ancient Offices of Britain (1999). 
Duchy of Cornwall Management Act 1863

Duchy of Cornwall Management Act 1868.

Duchy of Cornwall Management Act 1982.

\section{Schedule 11: Duchy of Cornwall - Mines}

1. Her Majesty and her lessees to have liberty to work such minerals through the lands of the Duchy. It shall be lawful at all times hereafter for Her Majesty, Her heirs and successors, and all and every persons and person who may for the time being be entitled in right of the Crown to or to the management of any of the said mines and minerals lying below low-water mark under the open sea, adjacent to but not being part of the county of Cornwall aforesaid, and for Her and their lessees or tenants, when and so often and so long as may be necessary for the purposes herein-after expressed, to take or use or to pass through, over, or under any lands for the time being parcel of the soil and territorial possessions of the said duchy within the said county, and which lands shall be either in the occupation of tenants under leases or agreements made subsequently to the date of this Act, or in the occupation of the duke of Cornwall for the time being, in order to make or sink any pits, shafts, adits, drifts, levels, drains, watercourses, pools, or embankments, and to make, lay, place, use, and repair any spoil banks, roads, ways, bridges, and banks, and to make, erect, and repair any lodges, sheds, steam and other engines, buildings, works, and machinery in, under, upon, through, over, or along the said lands, or any part thereof, which may from time to time or at any time hereafter be required, and to do all such other acts as may be necessary or convenient for working, searching for, digging, raising, or carrying away, dressing, or making merchantable the same mines and minerals, giving to the duke of Cornwall for the time being, and to any other person or persons who for the time being may be interested in the land so required, two months previous notice thereof, stating the nature of the facilities required, and also making compensation and satisfaction to the duke of Cornwall for the time being, and to other the person or persons, if any, for the time being interested in the said lands so taken or used or passed through, over, under, or along in the manner herein mentioned: provided always, that no pit, shaft, adit, drift, level, drain, watercourse, pool, or embankment which shall or may weaken, damage, injure, or endanger any house or other building, shall be sunk, driven, or made, nor shall any tramroad, waggon, or other way, or any works or machinery, be placed, laid, made, or erected, nor shall any minerals be dressed or made merchantable within fifty feet of any dwelling house, or upon any garden or orchard, or so as to interfere with any mining works or operations for the time being of the duke of Cornwall for the time being, his lessees or tenants.

2. Mode of ascertaining compensation. In all cases where the said facilities or any of them shall be used upon, through, over, under, or along lands lying between high-water mark and low-water mark part of the soil and territorial possessions of the duchy of Cornwall, the compensation and satisfaction to be made shall be a sum equal to one fifteenth part of the nett dues or moneys to be from time to time received by Her Majesty, Her heirs or successors, from the mines and minerals lying below low-water mark as aforesaid, which shall be worked and gotten by means of the said facilities, or any of them, in addition to compensation and satisfaction for or in respect of any building, wharf, or other artificial structure on the said lands which may be injuriously affected by the said facilities being used upon, through, over, under, or along the same, such compensation and satisfaction to be settled in the same manner as the compensation and satisfaction hereinafter provided for; and that when the said facilities or any of them shall be used on, through, over, under, or along any land other than lands lying between high-water mark and low-water mark as aforesaid, if the amount of compensation and satisfaction to be made for the same shall not be determined by agreement, then and in every such case the matter in difference shall be settled by arbitration by two arbitrators, one arbitrator to be named by the officer for the time being having the management of the land revenues of the Crown in Cornwall, and another arbitrator to be named by the duke of Cornwall for the time being, or by the council of the duchy for the time being, or by other the person or persons, if any, for the time being interested in the said lands so to be used as aforesaid, and the matter in difference shall be determined by the said arbitrators, or by an umpire to be appointed by them before they shall enter upon the reference; and if such arbitrators or either of them, or such umpire, shall die or refuse or for seven days neglect to act, other persons or another person shall forthwith be named or appointed to supply the places or place of the persons or person so dying or refusing or neglecting to act, in the same manner as such last-mentioned persons or person were or was named or appointed; and further, the said arbitrators or umpire shall determine by whom and how the costs of the reference and award or umpirage shall in each case be paid, and they or he may call for any documents in the possession or power of either of the parties which may be deemed necessary for determining the matter in difference, and may summon and examine upon oath any witness, and administer the oath for that purpose.

3. Interpretation of terms. In this Act the following expressions and words shall have the several meanings hereby assigned to them, unless there is something in the context repugnant to such construction; the expressions "Duke of Cornwall" and "duke of Cornwall for the time being" shall comprehend the personage for the time being entitled to the revenues of the duchy of Cornwall, and shall include Her Majesty, Her heirs and successors, when there may be no duke of Cornwall; the expression "Mines and Minerals" shall comprehend all mines and minerals, and all quarries, veins, or beds of stone, and all substrata of any other nature whatsoever, and the ground and soil in, upon, and under which such mines and minerals, quarries, veins, or beds of stone, and other substrata lie; and the words "the County of Cornwall" shall mean the said county exclusive of any lands added thereto or taken therefrom by the Counties (Detached Parts) Act 1844.

\section{Schedule 12: Privy Council Declaration}

Declaration to the President of the Privy Council (or his delegate):

'I promise I will keep secret all matters discussed in Council.'

Schedule 13: Cancelled City of London and Cinque Ports Charters

(a) City of London Charters

\section{Charter}

$1^{\text {st }}$ Charter $\underline{\text { Sovereign }}$

William I

\section{Date of Charter}

c. 1067 (in Anglo-Saxon) 


\begin{tabular}{|c|c|c|}
\hline$\left[2^{\text {nd }}\right.$ Charter & William I & ? (in Anglo-Saxon). ${ }^{401}$ \\
\hline Charter & Henry I & c. $1132 / 3$ \\
\hline Charter & Henry II & c. 1155 \\
\hline $1^{\text {st }}$ Charter & Richard I & 23 April 1194 \\
\hline $2^{\text {nd }}$ Charter & & 14 July 1197 \\
\hline $1^{\text {st }}$ Charter & John & 17 June 1199 \\
\hline $2^{\text {nd }}$ Charter & & 17 June 1199 \\
\hline $3^{\text {rd }}$ Charter & & 5 July 1199 \\
\hline $4^{\text {th }}$ Charter & & 20 March 1202 \\
\hline $5^{\text {th }}$ Charter & & $9^{\text {th }}$ May 1215 \\
\hline Charter & Henry III & 23 December 1226 \\
\hline $1^{\text {st }}$ Charter & & 18 February 1227 \\
\hline $2^{\text {nd }}$ Charter & & 18 February 1227 \\
\hline $3^{\text {rd }}$ Charter & & 18 February 1227 \\
\hline $4^{\text {th }}$ Charter & & 16 March 1227 \\
\hline $5^{\text {th }}$ Charter & & 18 August 1227 \\
\hline Charter $r e$ Queenhithe & & 26 February 1247 \\
\hline $6^{\text {th }}$ Charter & & 12 June 1253 \\
\hline $7^{\text {th }}$ Charter (of Remission) & & 10 January 1266 \\
\hline Charter & & 11 January 1266 \\
\hline $8^{\text {th }}$ Charter & & 26 March 1268 \\
\hline Charter of Confirmation & Edward I & 18 April 1298 \\
\hline Constitutions ( $1^{\text {st }}$ Charter) & Edward II & 8 June 1319 \\
\hline $2^{\text {nd }}$ Charter & & 12 December 1321 \\
\hline $1^{\text {st }}$ Charter & Edward III & 6 March 1327 \\
\hline $2^{\text {nd }}$ Charter & & 6 March 1327 \\
\hline 3rd Charter & & 26 March 1337 \\
\hline Charter & & 26 May 1341 \\
\hline Charter & & 3 June 1341 \\
\hline 4th Charter & & 10 June 1354 \\
\hline $5^{\text {th }}$ Charter & & 12 November 1376 \\
\hline $6^{\text {th }}$ Charter & & 4 December 1376 \\
\hline Charter & Richard II & 4 December 1377 \\
\hline Charter & & 26 November 1383 \\
\hline Charter/Letter & & 8 March 1384 \\
\hline $1^{\text {st }}$ Charter & Henry IV & 25 May 1400 \\
\hline $2^{\text {nd }}$ Charter & & 23 July 1406 \\
\hline Charter & Henry V & [ ] $1415^{402}$ \\
\hline Charter & & {[]$_{1420^{403}}$} \\
\hline Charter & Henry VI & 26 October 1444 \\
\hline $1^{\text {st }}$ Charter & Edward IV & 9 November 1462 \\
\hline $2^{\text {nd }}$ Charter & & 27 August 1463 \\
\hline $3^{\text {rd }}$ Charter & & 20 June 1478 \\
\hline $4^{\text {th }}$ Charter & & 20 June 1478 \\
\hline Charter & Henry VII & 22 August 1485 \\
\hline Charter & Henry VIII & 12 July 1509 \\
\hline $1^{\text {st }}$ Charter & & 16 June 1518 \\
\hline $2^{\text {nd }}$ Charter & & 13 April 1531 \\
\hline Charter & Edward VI & 23 April 1550 \\
\hline Charter & Mary & 1 March 1553 \\
\hline Charter & Elizabeth & 9 March 1572 \\
\hline $1^{\text {st }}$ Charter & James I & 20 August 1605 \\
\hline $2^{\text {nd }}$ Charter & & 20 September 1608 \\
\hline $3^{\text {rd }}$ Charter & & 15 September 1614 \\
\hline $1^{\text {st }}$ Charter* & Charles I & 18 October 1638 \\
\hline $2^{\text {nd }}$ Charter & & 5 September 1640 \\
\hline Charter & Charles II & 24 June 1663 \\
\hline Charter & William III & 28 July 1692 \\
\hline Charter & George II & 25 August 1741 \\
\hline
\end{tabular}

${ }^{401}$ This should be excluded since not a charter to the City as such but to an individual.

${ }^{402}$ The Corporation of London would be able to confirm whether this charter exists and any date (possibly, it is of 12 July 1415)...

${ }^{403}$ Ibid (possibly, it is of 6 October 1420). 
Further (possible) charters beyond these may be: ${ }^{404}$

- $\quad$ One of inspeximus of Edward I of 17 April 1299

- $\quad$ One of Edward I, dis-warrening the warren of Staines, perhaps, of 12 October 1297

- $\quad$ One of Richard II of 23 July 1396.

\section{(b) Cinque Ports Charters}

Charter

$\underline{\text { Sovereign }}$

\section{Date of Charter}

Any charter granted by the Crown to the Cinque Ports prior to 17 June 1278

Charter

Edward I

17 June 1278

Letters Patent

28 April 1298

Letters Patent

28 April 1298

Charter

Edward II

Charter

Edward III

26 July 1313

Charter

Richard II

Charter

Edward IV

5 February 1326

1 July 1364

Charter

Henry VII

22 January 1378

Charter

Henry VIII

Charter

Edward VI

Charter

Mary I

Charter

Elizabeth I

23 March 1465

13 December 1487

5 March 1510

20 November 1548

Letters Patent

James I

27 October 1553

Charter

Charles I

March 1559

Charter

Charles II

Charter

16 June 1634

23 December 1668

Schedule 14: Repealed Crown Legislation

Statute concerning Tallage 1297

Confirmation of the Charters 1297

Prerogativa Regis (temp incert)

Revocation of the New Ordinances 1322

The Status of Children Born Abroad 1350-1

Treason Act 1351

Confirmation of Liberties 1405-6

Confirmation of Charters and Statutes 1415-6

Confirmation of Liberties 1423

Appointment of Bishops Act 1533

Crown Lands Act 1623

Statute of Monopolies 1623

Petition of Right 1627

Tenures Abolition Act 1660

Free and Voluntary Present to his Majesty 1661

Bill of Rights 1688, art 1,

repeal the words "when a man doth compass or imagine the death of our lord the king, or of our lady his queen or of their eldest son and heir; or if a man do violate the king's companion, or the king's eldest daughter unmarried, or the wife of the king's eldest son and heir.'

repeal in s 4 any reference to making an oath of homage and of fealty.

repeal in $\mathrm{s} 1$ from 'that the pretended power of suspending of laws' up to 'for such petitioning are illegal.'

repeal in $\mathrm{s} 1$ from 'that excessive bail' up to 'are illegal and void' repeal in $\mathrm{s} 1$, the words from 'to which demand of their rights they are particularly encouraged...' up to the words 'against all persons whatsoever that shall attempt any thing to the contrary...' . Also, the words from 'and that every king and queen of this realm' up to the words 'shall have attained the said age of twelve'.

Coronation Oath Act 1688

Convention Parliament Act 1688

Royal Mines Act 1688

Great Seal Act 1688

Crown and Parliament Recognition Act 1689

Royal Mines Act 1693

Act of Settlement 1700

repeal s 1

in section 2 repeal the words 'and that every king and queen of this realm who shall come to and succeed in the imperial Crown of this kingdom by virtue of this Act shall have the Coronation Oath administered to him her

${ }^{404}$ Ibid. 
Crown Lands Act 1702

Demise of the Crown Act 1702

Act of 6 Anne 1702

Union with Scotland Act 1706

Union with England Act 1707

Succession to the Crown Act 1707

Princess Sophia's Precedence Act 1711

Demise of the Crown Act 1727

Representation of the People Act 1867

Great Seal (Offices) Act 1874

Crown Office Act 1877

Great Seal Act 1884

Sheriffs Act 1887

Crown Office Act 1890

Demise of the Crown Act 1901

Accession Declaration Act 1910

Titles Deprivation Act 1917

Statute of Westminster 1931

His Majesty's Declaration of Abdication Act 1936

Regency Act 1937

Osborne Estate Act 1902

Regency Act 1943

Regency Act 1953

Royal Titles Act 1953

Treasure Act 1996

Also,

Naval Prize Act 1864

Prize Courts Act 1894

Prize Courts (Procedure) Act 1914

Prize Courts Act 1915

Naval Prize (Procedure) Act 1916

Prize Act 1939

Prize Salvage Act 1944 [for these see s 17 of the Crownt Act] or them at their respective coronations according to the Act of Parliament made in the first year of the reign of His Majesty and the said late Queen Mary intituled An Act for establishing the Coronation Oath and shall make subscribe and repeat the declaration in the Act first above recited mentioned or referred to in the manner and form thereby prescribed.' in section 3 repeal the words 'That whosoever shall hereafter come to the possession of the Crown shall join in communion with the Church of England as by law established.'

repeal s 3(2)

repeal s 2

in art 2 repeal the words 'That the succession to the monarchy of the United Kingdom of Great Britain and of the dominions thereto belonging after her most sacred majesty and in default of issue of her Majesty be remain and continue to the most excellent princess Sophia electoress and dutchess dowager of Hanover and the heirs of her body being protestants upon whom the Crown of England is settled by an Act of Parliament made in England in the twelfth year of the reign of his late Majesty king William the Third intituled an Act for the further Limitation of the Crown and better securing the rights and Liberties of the Subject.'

in art 25(3) repeal the words 'and be it further enacted by the authority aforesaid that after the demise of her majesty (whom God long preserve) the sovereign next succeeding to her Majesty in the royal government of the kingdom of Great Britain and so for ever hereafter every king or Queen succeeding and coming to the royal government of the kingdom of Great Britain at his or her Coronation shall in the presence of all persons who shall be attending assisting or otherwise then and there present take and subscribe an oath to maintain and preserve inviolably the said settlement of the Church of England and the doctrine worship discipline and government thereof as by law established within the kingdoms of England and Ireland the dominion of Wales and Town of Berwick upon Tweed and the Territories thereunto belonging.'

in art 2 repeal the words 'That the succession to the monarchy of the United Kingdom of Great Britain and of the dominions thereto belonging after her most sacred majesty and in default of issue of her Majesty be remain and continue to the most excellent princess Sophia electoress and dutchess dowager of Hanover and the heirs of her body being protestants upon whom the Crown of England is settled by an Act of Parliament made in England in the twelfth year of the reign of his late Majesty king William the Third intituled an Act for the further Limitation of the Crown and better securing the rights and Liberties of the Subject.'

repeal, s 51

repeal s 3(3)

in the Preamble, repeal paragraph 2.

repeal ss 4(1) and 5 


\section{Schedule 15: Repealed Church of England Related Legislation}

Supremacy Act 1558

Bill of Rights 1668

Act of Settlement 1700

Act of Union with Scotland Act 1706

Act of Union with England Act 1707 in $\mathrm{s} 1$ delete "whereas it hath been found by experience that it is inconsistent with the safety and welfare of this protestant kingdom to be governed by a popish prince...the said Lords spiritual and temporal and Commons do further pray that it may be enacted that all and every person and persons that is are or shall be reconciled to or shall hold communion with the see or church of Rome or shall profess the popish religion... shall be excluded and be for ever incapable to inherit possess or enjoy the Crown and government of this realm and Ireland and the dominions thereunto belonging or any part of the same or to have use or exercise any regal power authority or jurisdiction within the same and in all and every such case or cases the people of these realms shall be and are hereby absolved of their allegiance and the said Crown and government shall from time to time descend to and be enjoyed by such person or persons being protestants as should have inherited and enjoyed the same in case the said person or persons so reconciled holding communion or professing....as aforesaid were naturally dead.

in s 2 delete 'Provided always and it is hereby enacted that all and every person and persons who shall or may take or inherit the said Crown by virtue of the limitation of this present Act and is are or shall be reconciled to or shall hold communion with the see or church of Rome or shall profess the popish religion...shall be subject to such incapacities as in such case or cases are by the said recited Act provided enacted and established.' [i.e. the Bill of Rights 1688].

in art 2 delete "that all papists... shall be excluded from and for ever incapable to inherit possess or enjoy the imperial Crown of Great Britain and the dominions thereunto belonging or any part thereof and in every such case the Crown and government shall from time to time descend to and be enjoyed by such person being a protestant as should have inherited and enjoyed the same in case such papist... was naturally dead according to the provision for the descent of the Crown of England made by another Act of Parliament in the first year of the reign of their late majesties king William and queen Mary intituled an Act declaring the rights and liberties of the subject and settling the succession of the Crown [i.e. the Bill of Rights 1688].

in art 2 delete "that all papists... shall be excluded from and for ever incapable to inherit possess or enjoy the imperial Crown of Great Britain and the dominions thereunto belonging or any part thereof and in every such case the Crown and government shall from time to time descend to and be enjoyed by such person being a protestant as should have inherited and enjoyed the same in case such papist... was naturally dead according to the provision for the descent of the Crown of England made by another Act of Parliament in England in the first year of the reign of their late majesties king William and queen Mary intituled an Act declaring the rights and liberties of the subject and settling the succession of the Crown.' [i.e. the Bill of Rights 1688].

\section{Schedule 16: Repealed Duchy of Cornwall Legislation}

Duchies of Lancaster and Cornwall (Accounts) Act 1838

Duchy of Cornwall Act 1844

Duchy of Duchy of Cornwall (No 2) Act 1844

Duchy of Cornwall Act 1863

Duchy of Cornwall Management Act 1868

Duchy of Cornwall Management Act 1982

Solicitor's Act 1974

Stannaries Act 1855

in $\mathrm{s} 88$ (1), repeal the words 'or the Duchy of Cornwall' repeal s 31

\section{Schedule 17: Cancelled Duchy of Cornwall Charters}

(a) any charter from the Crown concerning the duchy of Cornwall prior to 17 March 1337, including a charter of:

(i) 10 August 1231 from the Crown to Richard, Earl of Cornwall;

(ii) 6 August 1307 from the Crown to Piers de Gaveston;

(iii) 1310 from the Crown to Piers de Gaveston and his wife, Margaret;

(iv) $25^{\text {th }}$ July 1318 from the Crown to Isabella, Queen of England;

(v) 10 October 1332 from the Crown to John of Eltham, Earl of Cornwall.

(b) a charter of 17 March 1337 from the Crown to the duchy.

(c) a charter of 18 March 1337 from the Crown to the duchy. 
(d) a charter of 3 January 1338 from the Crown to the duchy.

(e) a writ under the Privy Seal of 9 July 1343 relating to the duchy.

\section{Schedule 18: Abolished Duchy of Cornwall Rights}

Any right of the duchy (or the Duke) to:

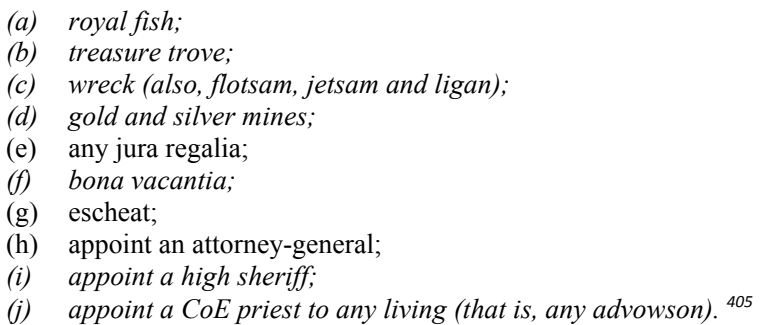

\section{Schedule 19: Repealed Duchy of Lancaster Legislation}

Duchy of Lancaster Act 1779

Duchy of Lancaster Act 1787

Duchy of Lancaster Act 1808

Duchy of Lancaster Act 1812

Duchy of Lancaster Act 1817

Duchy of Lancaster (Accounts) Act 1838

Duchy of Lancaster Lands Act 1855

Duchy of Lancaster Act 1920

\section{Schedule 20: Obsolete Courts}

(a) the courts referred to in the Administration of Justice Act 1977, sch 4, parts 1, 2 and $3 .{ }^{406}$

(b) Court of the Chamberlain of the City of London. ${ }^{407}$

(c) Court of the Duchy Chamber of Lancaster. ${ }^{408}$

(d) High Court of Chivalry. ${ }^{409}$

(e) Cinque Ports Court of Admiralty. ${ }^{410}$

(f) Courts of the Vice-Admirals of the Coast. ${ }^{411}$

(g) Court of the Lord High Steward. ${ }^{412}$

(h) Court of Claims. ${ }^{413}$

(i) Court of Attachment (40 Days Court) of the New Forest.

(j) Court of Attachment (40 Days Court) of the Forest of Dean.

(k) Court of the Verderers of the Forest of Dean. ${ }^{414}$

(l) the Barmote courts of the High Peak and Wirksworth. ${ }^{415}$

(m) the Royal Court of Shepway and the Court of Brotherhood and Guestling in the Cinque Ports, without prejudice to their sitting to elect (for ceremonial purposes) a Lord Warden of the Cinque Ports. ${ }^{416}$

405 This Act seeks to abolish the matters in italics. Therefore, they need not be expressly referred to (they are also covered by (e)).

406 These courts can no longer hear cases since 1977. Legislation should state that the abolition of any manorial court shall not affect the status of the manor.

407 This court has not sat for 100 years. It is, also, not a true court.

408 This court last sat in 1853 .

${ }^{409}$ This court last sat in 1954 and, prior to that, in 1737. Any civil jurisdiction it still has in respect of armorial matters should pass to the High Court.

${ }^{410}$ This court has not sat since 1914. Any maritime jurisdiction it still has should pass to the High Court, Admiralty division

411 These courts have long been defunct.

412 This court covered impeachment trials when Parliament was not sitting (otherwise the Lord Chancellor sits). It last sat in the $17^{\text {th }}$ century. It may be noted that impeachment trials could still be heard with the Lord Chancellor sitting. That said, the HL can no longer hear impeachments since it no longer has judges (see also European Human Rights Convention, art 6).

413 This court hears coronation claims. It is not a true court. If abolished, those personal retainers the sovereign wishes to attend the coronation should be set out in an SI.

${ }^{414}$ It last sat in 1902. It should be abolished.

415 These are long defunct. They dealt with mining claims in Derbyshire.

${ }^{416}$ These 'courts' have long ceased to exercise legal jurisdiction. 


\section{Schedule 21: Disclaimer of a Hereditary Peerage}

\section{Disclaimer of certain Hereditary Peerages}

(1) Subject to the provisions of this section, any person who succeeds to a peerage in the peerage of England, Scotland, Great Britain or the UK may, by an instrument of disclaimer delivered to the Lord Chancellor within the period prescribed by this Act, disclaim that peerage for his life.

(2) Any instrument of disclaimer to be delivered under this section in respect of a peerage shall be delivered within the period of twelve months beginning with the day on which the person disclaiming succeeds to that peerage or, if he is under the age of twenty-one when he so succeeds, the period of twelve months beginning with the day on which he attains that age; and no such instrument shall be delivered in respect of a peerage by a person who is excepted from section 1 of the House of Lords Act 1999 by virtue of section 2 of that Act.

(3) In reckoning any period prescribed by this section for the delivery of an instrument of disclaimer by any person no account shall be taken of any time during which that person is shown to the satisfaction of the Lord Chancellor to have been subject to any infirmity of body or mind rendering him incapable of exercising or determining whether to exercise his rights under this section.

(4)The provisions of Schedule shall have effect with respect to the form of instruments of disclaimer under this section, and the delivery, certification and registration of such instruments.

\section{Effects of Disclaimer}

(1)The disclaimer of a peerage by any person under section 1 shall be irrevocable and shall operate, from the date on which the instrument of disclaimer is delivered, -(a) to divest that person (and, if he is married, his wife) of all right or interest to or in the peerage, and all titles, rights, offices, privileges and precedence attaching thereto; and (b) to relieve him of all obligations and disabilities arising therefrom, but shall not accelerate the succession to that peerage nor affect its devolution on his death.

(2)Where a peerage is disclaimed under section 1, no other hereditary peerage shall be conferred upon the person by whom it is disclaimed.

(3)The disclaimer of a peerage under section 1shall not affect any right, interest or power (whether arising before or after the disclaimer) of the person by whom the peerage is disclaimed, or of any other person, to, in or over any estates or other property limited or settled to devolve with that peerage.

(4) The reference in the foregoing subsection to estates or other property limited or settled to devolve with a peerage shall, for the purposes of the application of this Act to Scotland, be construed as including a reference to estates or other land devolving as aforesaid under an entail or special destination, or the beneficial interest in which so devolves under a trust.

\section{Scottish Peerage}

The holder of a peerage in the peerage of Scotland shall have the same right to receive writs of summons to attend the House of Lords, and to sit and vote in that House, as the holder of a peerage in the peerage of the UK.

\section{Peeresses in own Right}

A woman who is the holder of a hereditary peerage in the peerage of England, Scotland, Great Britain or the UK shall (whatever the terms of the letters patent or other instrument, if any, creating that peerage) have the same right to receive writs of summons to attend the House of Lords, and to sit and vote in that House, and shall be subject to the same disqualifications in respect of membership of the House of Commons and elections to that House, as a man holding that peerage.

\section{SCHEDULE 1: FORM, DELIVERY, CERTIFICATION AND REGISTRATION OF INSTRUMENTS OF DISCLAIMER}

1.An instrument of disclaimer under this Act shall be an instrument under seal in the following form or any form to the like effect:

Whereas I,, succeeded to the peerage[s] described in the Annex hereto on the date[s] specified in that Annex, and desire to disclaim the said peerage[s] for my life under the above mentioned Act; And whereas I attained the age of 21 years [before the said date[s]] [on theday of]; Now therefore, I, the said, in accordance with the provisions of the said Act, hereby disclaim the said peerage[s] for my life.

In witness whereof I have hereunto set my hand and seal this day of Signed and sealed by the said in the presence of:

Signature of Witness

Address

Description

Description of Peerage
(LS) Signature

$\underline{\text { Annex }}$

Date of this Succession

2. Any instrument of disclaimer shall be delivered to the office of the Clerk of the Crown in Chancery.

3. Where the Lord Chancellor is satisfied that an instrument of disclaimer in respect of a peerage has been delivered within the time allowed by this Schedule, he shall furnish to the person disclaiming the peerage a certificate to that effect, and shall cause particulars of the instrument and of his certificate to be entered in a register kept by him for the purpose, which shall be open to inspection by the public at all reasonable times.

4.A certificate of the Lord Chancellor that an instrument of disclaimer was delivered within the time allowed by this Schedule shall be conclusive evidence of that fact, but shall not be evidence of any other matter relevant to the validity of the instrument, including the right of the person by whom it was delivered to any peerage to which it relates. 


\section{Schedule 22: Private Estate of the Sovereign}

Part A. [This will set out any material in Part B deemed worthy of retention].

Part B. Repealed Legislation

Crown Private Estate Act 1800

Crown Lands Act 1823

Crown Private Estates Act 1862

Crown Private Estates Act 1873 [for these, see s 1(7) of the Crown Act]

\section{Copyright}

Copyright for this article is retained by the author(s), with first publication rights granted to the journal.

This is an open-access article distributed under the terms and conditions of the Creative Commons Attribution license (http://creativecommons.org/licenses/by/4.0/). 